AGNIESZKA PISANKO-BOROWIK (Białystok)

\title{
TESTAMENTY MIESZCZAN GRODZIEŃSKICH W XVII-XVIII WIEKU
}

\section{Stan badań i wykorzystanie źródeł}

Zainteresowanie testamentami ma długą tradycję. Wykorzystywano je jako materiał pomocniczy, będący źródłem cennych informacji dotyczących życia codziennego. Mam na myśli prace historyków stanowiące syntetyczne ujęcie ówczesnej obyczajowości ${ }^{1}$, genealogów oraz prace poświęcone dziejom miast i mieszczaństwa ${ }^{2}$.

Coraz częściej testamenty stanowią podstawową bazę źródłową do badaí nad wieloma aspektami funkcjonowania społeczeństwa staropolskiego. Tematyka, którą w oparciu o ten typ źródła próbowano badać jest niezwykle bogata. Poza wspominaną już kwestią ekonomiczno-materialną, również: zagadnienia prawne ${ }^{3}$; strukturę spadkobrania - teoria i praktyka- stosu-

1 W. Łoziński, Życie polskie w dawnych wiekach, wyd. II, Kraków 1978; tegoż, Prawem $i$ lewem. Obyczaje na czerwonej Rusi w pierwszej polowie XVII wieku, t. I, Lwów 1931; J. S. Bystroń, Dzieje obyczajów w dawnej Polsce wiek XVI-XVIII, t. II, Warszawa 1976; Z. Kuchowicz, Obyczaje staropolskie XVII-XVIII wieku, wyd. I, Łódź 1975.

2 W. Łoziński, Patrycjat i mieszczaństwo lwowskie w XVI i XVII wieku, Lwów 1902; H. Samsonowicz, Badania nad kapitalem mieszczańskim Gdańska w II polowie XV wieku, Warszawa 1960; tegoż, Późne średniowiecze miast nadbaltyckich. Studia nad dziejami Hanzy nad Baltykiem $w X I V-X V w$., Warszawa 1986; A. Karpiński, Pauperes. O mieszkańcach Warszawy XVI i XVII wieku, Warszawa 1967; Dzieje Warszawy, red. S. Kieniewicz, t. II: Warszawa $w$ latach 1525-1795, Warszawa 1984; M. Bogucka, H. Samsonowicz, Dzieje miast $i$ mieszczaństwa $w$ Polsce przedrozbiorowej, Wrocław 1986.

3 P. Iąbkowski, Prawo prywatne polskie, t. 2, Lwów 1911; K. Bukowska, Orzecznictwo krakowskich sq̨dów wyższych $w$ sporach o nieruchomości miejskie (XVI-XVIII w.). Studium $z$ historii prawa rzymskiego $w$ Polsce, Warszawa 1967; B. Groicki, Tytuly prawa magdeburskiego, wyd. K. Koranyi. Biblioteka Dawnych Polskich Pisarzy-Prawników, 1. III, Warszawa 1954; tegoż, Artykuly prawa majdebur.skiego, które zowiq Speculum Saxonum z lacińskiego języka na polski przelożone z znowu drukowane roku pańskiego 1629, Kraków 1629 (reprint, Warszawa 1954). 
nek dziedziczenia ustawowego do dziedziczenia testamentowego ${ }^{4}$; stosunki i więzi rodzinno-społeczne ${ }^{5}$; mentalność i religijność tematykę związaną z ceremoniami pogrzebowymi oraz religijnością poszczególnych grup społecznych 6 .

$\mathrm{Na}$ bazie pojedynczych testamentów powstało szereg ciekawych i interesujących opracowań ${ }^{7}$. Odrębną kwestię stanowią edycje testamentów, które odtwarzają typy źródeł zawartych w księgach miejskich czy ziemskich. Ukazały się zbiory testamentów szlacheckich ${ }^{8}$, miesıc:zańskich ${ }^{9}$ i chłopskich ${ }^{10}$.

4 J. Rafacz, Wlościańskie prawo spadkowe w Polsce Nowożytnej, w: Zwyczaje spadkowe wlościan w Polsce, cz. 5, Warszawa 1929, s. 1-37, rec. J. Adamus, „Roczniki Dziejów Społecznych i Gospodarczych" 1931, nr 1, s. 229-233; K. Dobrowolski, Wlościańskie rozporzqdzenia ostatniej woli na Podhalu $w$ XVII $i$ XVIII w., Kraków 1933; K. Orzechowski, $O$ ślqskich źródlach do poznania chlopskiego prawa spadkowego $w$ późnym feudalizmie, „Śląski Kwartalnik Historyczny Sobótka”, t. 19, 1964, nr 1, s. $78-87$; A. Walawender, Zwyczaje $i$ udzialy spadkowe chlopów we wsi Kargowa powiatu kościańskiego $w$ Wielkopolsce w pierwszej polowie XVII w., „Etnografia Polska”, R. 2, 1959, s. 145-156; K. Bukowska, op. cit.; M. Sadyka, Instytucje prawa chelmińskiego w Warszawie XVI wieku, w: Warszawa średniowieczna, Warszawa 1975.

5 S. Hołdys, Więzi rodzinne $w$ świetle mieszczariskich testamentów z pierwszej polowy XVII $w$., „Studia Historyczne”, R. 29, 1986, z. 3, s. 347-357 (rec. M. Górny, W sprawie badania rodziny staropolskiej na podstawie testamentów, „Studia Historyczne”, R. 30, 1987, z. 3, s. 487-494); K. Zielińska, Więzi spoleczne na Mazowszu w polowie XVII wieku w świetle testamentów konsystorza pultuskiego, „Przegląd Historyczny” 1986, t. LXXVII, z. 1, s. $45-59$.

6 H. Zaremska, Żywi wobec zmarlych. Brackie i cechowe pogrzeby w Krakowie $w$ XIV - pierwszej polowie XVI w., „Kwartalnik Historyczny”, t. 81, 1974, z. 4, s. 733-749; tejże, Bractwa w średniowiecznym Krakowie, Warszawa 1977; A. Karpiński, Zapisy „poboż$n e "$ i postawy religijne mieszczanek polskich $w$ świetle testamentów z drugiej polowy XVI i XVII $w$., w: Tryumfy i porażki, Warszawa 1986, s. 204-233; tenże, Kobieta $w$ mieście polskim $w$ drugiej polowie XVI i $w$ XVII wieku, Warszawa 1995; M. Aleksandrowicz-Szmulikowska, Radziwillówny w świetle swoich testamentów. Przyczynek do badania mentalności magnackiej w XVI-XVII wieku, Warszawa 1995 (zob. rec. M. Górny, „Genealogia”, t. 7, 1996, s. 137-139); J. Dumanowski, Pompa Funebris? Z testamentów szlachty wielkopolskiej z XVIII w., w: Śluby, chrzciny, pogrzeby $w$ XVI-XVIII w. kultura życia i śmierci, pod red. H. Suchojada, Warszawa 2001, s. 315-322.

7 M. Bogucka, Testament burmistrza gdańskiego Hansa Speymana z 1625 r., w: Kultura średniowieczna i staropolska. Studia ofiarowane Aleksandrowi Gieysztorowi w pięćdziesiçciolecie pracy naukowej, Warszawa 1991, s. 587-593; tejże, Czy mincerze byli bogaci? Testament Anny, wdowy po gdańskim mincerzu Filipie Cluverze (1616 r.), w: Ojczyzna bliższa i dalsza. Studia historyczne ofiarowane Feliksowi Kirykowi w sześćdziesiątq rocznicę urodzin, Kraków 1993, s. 457-459 (w pracach tych nie opublikowano testamentów).

8 J. Sygański, Z życia domowego szlachty sqdeckiej w epoce Wazów, Lwów 1910, s. 96-104 (w aneksie opublikował kilka testamentów); M. Borkowska, Dekret w niebieskim ferowany parlamencie. Wybór testamentów z XVII-XVIII wieku, Kraków 1984 (opublikowała 26 testamentów szlachty z XVII-XVIII wieku pochodzących $\mathrm{z}$ archiwum benedyktynek wileńiskich oraz jeden mieszczański); U. Augustyniak, Testamenty ewangelików reformowanych $w$ Wielkim Księstwie Litewskim, Warszawa 1992 (opublikowała 16 testamentów; zob. rec. A. Rachuba, „Kwartalnik Historyczny” 1992, nr 4, s. 143-147; również: 
Znacznie częściej publikowano pojedyncze testamenty zarówno szlacheckie $^{11}$ jak i mieszczańskie ${ }^{12}$. Ich wybór nie był przypadkowy. Są to bowiem

Andrzej B. Zakrzewski, „Przegląd Historyczny”, t. 83, 1992, z. 3, s. 577-580); Testamenty szlachty krakowskiej XVII-X VII w. Wybór tekstów źródlowych z lal 1650-1799, opr. Alic ja Falniowska-Gradowska, Kraków 1997 (opublikowała 41 testamentów zróżnicowanych pod względem majątkowym, sytuacji rodzinnej, okoliczności spisywania ostatniej woli. 12 z drugiej polowy XVII i 29 z wieku XVIII).

9 Testamenty mieszczan wojnickich 1.599-1809, opr. P. Iymmel, Wojnicz 1997, seria: Biblioteka historyczna - Towarzystwo Przyjaciół Ziemi Wojnickiej, t. 14.

10 K. Dobrowolski, op. cit. (opublikował 120 testamentów z lat 16.19 1791).

11 Testament Stanislawa Koniecpolskiego kasztelana krakowskiego, w: S. Przyłęcki, Pamic̨tniki o Koniecpolskiech, Lwów 1842, s. 288-292; Testament Stefana Korycińskiego kanclerza koronnego, w: K. Hoszowski, O znakomitych zaslugach dla kraju rodziny Koryciń.skich, Kraków 1862, s. 91-124; 'T. Wasilewski, Testament Ostafiego Wollowicza, w: Odrodzenie i Reformacja w Polsce, t. VII, Warszawa 1962, s. 165-173; S. Achremczyk, Testament kanclerza wielkiego koronnego i biskupa warnnińskiego Andrzeja Chryzostoma Zaluskiego, „Komunikaty Mazursko-Warmińskie” 1984 [druk 1985], nr 4, s. 375-397; (i. Blaszczyk, Chryzostom Wolodkiewicz - zapomniany pisarz i jego testament, „Lituano-Slavica Posnanienisa. Studia Historica" 1989, nr 3, s. 203-232; U. Augustyniak, Wizerunek Krzysztofa II Radziwila jako magnata-ewangelika w świetle jego testamentów, „Przegląd Historyczny”, t. 81, 1990, z. 3-4, s. 461-477; M. Górny, Testament Cecylii z Dzialyńskich Baranowskiej z 1736 roku, „Genealogia. Studia i materiały hist.oryczne", t. 7, Poznań - Wrocław 1996, s. 112-114; Testament A. S. Radziwilla, kanclerza wielkiego litewskiego, spisany najpierw we wsi Wda 8 marca 1655 r.. a potem uzupelniony $w$ Gdańsku 12 sierpnia $1656 r$., w: A. S. Radziwill, Memoriale rerum gestorum in Polonia 1632-1656, opr. A Przyboś, R. Żelewski, t. IV 1648-1656, Wrocław 1974, s. $325-340$. Pojedyncze testamenty szlacheckie publikowano téz w różnych zbiorach dokumentów, np.: Ажты издаваемые Вйлекскою Археографическою Комміссиею для разбора древнитъ актовъ, t. I, Вильна 1865, nr 6, s. 27-30; t. XVII, Вильна 1890, nr 987, s. 406-7, nr 1009, s. 433-5, nr 1012, s. 438-9; t. XXI, Вильна 1894, пг 13, s. 7; t. XXII, Вильна $1895, \mathrm{nr} 462$, s. 247-8, nr 570, s. 306-308, nr 620, s. 373-5; Lietuvos Metrika. Knyga nr 8 (8] (14.99-1514). Użašynny knyga 8, parengè: A. Baliulis, R. Firkovičius, D. Antanavičius, Vilnius 1995, $\mathrm{nr}$ 365, s. 281-2; Метрыка Вялікага Княства Лimogскага. Кніга 43 (1523-1560). Кніга запісау 43, падр. В. С. Мянжынскі, Мінск 2003, nr 3, s. 47-48, nr 11, s. 55-6, nr 20, s. 65-7, nr 41, s. 92-4; Lietuvos Metrika. Knyga $n r 51$ [51] (1566-1574). Uż̀ašymy knyga 51, parengè: A. Baliulis, R. Ragauskienè, A. Ragauskas, Vilnius 2000, nr 82, s. 90-1, nr 40, s. 61-3; Lietuvos Metrika. Knyga $n r 530$ (8) (1566-1572). Viešuju reikalu knyga 8, parengè: D. Baronas, L. Jovaisa Vilnius 1999, nr 58, s. 57-61; Lietuvos magdeburginiщ miesty privilegijos ir aktai, t. 2, sudarè: A. Tyla, D. Żygelis, Vilnius 1997, nr 3, s. 38-43. Ograniczylan się tu i w przypisie następnym do podania garści przykładów. Dziesiątki testamentów z terenu Wielkiego Księstwa Litewskiego opublikowano w różnych seriach wydawniczych źródeł. Orientację w bogactwie wydawnictw źródłowych ułatwia praca H. Н. У'лапчика, Очерки по археографии и источниковедению истории Белоруссии феодального периода, Москва 1973, a także wydane pośmiertnie jej uzupełnienie Працы по археаграфии и крынічазнауства аісторьі Беларусі а рукописнай спадчыны, Мінск 1999.

12 Pięć testamentów mieszczan płockich z lat 1492-1495 opublikowano w: Zbiór dokumentów i listów miasta Plocka, t. l, wyd. S. M. Szacherska, Warszawa 1975, s. 352-354, 359-367; F. Stolot, Testament Tomasza Nikla. Przyczynek do dziejów pińczowskich warsztatów budowlanych i kamieniarsko-rzeźbiarskich na przelomie wieków XVI i XVII, „Biule- 
dyspozycje ostatniej woli ludzi, których śmiało możemy zaliczyć do osób postawionych na świeczniku opinii publicznej, członków znanych i zamożnych rodów, przedstawicieli patrycjatu miejskiego, osób zasłużonych lub takich, które $\mathrm{z}$ tych czy innych przyczyn na trwałe wpisały się w karty naszej historii. Publikowano testamenty ze względu na samą wartość źródła, jego niepowtarzalność i unikatowość w sensie dokumentu, w którym przemawia sam człowiek, niejednokrotnie zamieszczano je również w formie aneksu.

Odrębną kwestię związaną $\mathrm{z}$ podejmowaną przeze mnie tematyką stanowią prace źródłoznawcze dotyczące wybranych zbiorów testamentów ${ }^{13}$.

\section{Testamenty mieszczan grodzieńskich - przedstawienie zbioru}

Testamenty mieszczan grodzieńskich, poza nielicznymi wyjątkami, nie były publikowane ani poddane analizie źródłoznawczej ${ }^{14}$. Wykorzystano je

tyn Historii Sztuki”, R.. 52, 1984, t. 3-4, s. 227-244; A. Falniowska-Gradowska i S. Gawęda, Testament sztygara wielickiego Sebastiana Koszutskiego z 1681 roku, w: Studia i materialy do dziejów żup solnych w Polsce, t. 17, 1992, s. 147-158; A. Falniowska-Gradowska, Z. Noga, Jan Sroczyński (1614-1696) mieszczanin krakowski i dzieje jego fundacji, „Rocznik Krakowski", t. 67, 2001, s. 19-47 (w aneksach zamieszczono testamenty osób wzmiankowanych w tytułach).

13 O. Hedemann, Testamenty braslawsko-dziśnieńskie XVII-XVIII wieku jako źródlo historyczne, Wilno 1935 (praca dotyczy 46 testamentów przede wszystkim szlacheckich w niewielkim stopniu zaś mieszczańskich. Autor wielokrotnie cytuje obszerne fragmenty testamentów, nie można ich jednak uznać, z czym się spotkałam, za edycję źródła); J. Krochmal, Przemyskie testamenty staropolskie, „Rocznik Historyczno-Archiwalny Archiwum Państwowego w Przemyślu", t. 6, 1989, s. 133-160); U. Sowina, Najstarsze testamenty mieszczańskie $z$ poczq̨tku XVI w. Analiza źnódloznawcza, „Kwartalnik Historii Kultury Materialnej", R. 39, 1991, z. 1, s. 3-25 (przeanalizowano 26 testamentów, zamieszczono równiėz ich wykaz); H. Żerek-Kleszcz, Testamenty mieszczan pabianickich $w$ XVII-XVIII wieku, „Pabianiciana” 1992, nr 1, s. 37-51 (Analizie poddano 27 testamentów, na konícu zamieszczono wykaz 30 testamentów zachowanych w księgach miejskich Pabianic); М. Гарлзееу, Н. Сліж, Шляхецкія тлэстменты 16 - пачатку $18 \mathrm{~cm}$., „Гістрычны алманах", т. 3, Гародня 2000, s. 90-110 (autorzy omówili 58 testamenlów szlacheckich, głównie opublikowanych w: J. Główka, Testamenty mieszczan kieleckich $z$ końca XVIII w. zwierciadlem epoki (w świetle księgi rady miejskiej Kielc 1789-1792), w: Wesela, chrzciny, pogrzeby w XVI-XVIII w. kultura życia i śmierci, pod red. H. Suchojada, Warszawa 2001, s. 323-332 (autor omówił 3 testamenty). Wypada zaznaczyć, że edycje testamentów zarówno zbiorowe jak i pojedyncze również poprzedzano analizą źródeł.

14 Акты издаваемые Вйленскою Археографическою Комміссіею для разбора древнитъ алтовъ, t. I, Вильна 1865, сz. I, nr 16, s. 55-6; E. Dubas-Urwanowicz, Pożegnanie $z$ doczesnościq Zygmunta Szulca, rajcy grodzień.skiego, „Miscellanea Historico-Archivistica", t. XI, 2000, s. 243-247; A. Pisanko-Borowik, Testament Karola Topolskie- 
też $\mathrm{w}$ niewielkim stopniu jako materiał uzupełniający, nie poświęcając im większej uwagi ${ }^{15}$.

Analizując akty ostatniej woli mieszkańców Grodna, zasadnym wydaje się przytoczenie kilku informacji o samym mieście, jego historii i znaczeniu.

Grodno usytuowane na wzgórzu, na prawym brzegu Niemna przy ujściu doń Horodniczanki, do dziś zachwyca swoją panoramą i wspaniałymi zabytkaini. Jego początki sięgają $\mathrm{X}$ wieku, stąd miasto zaliczane jest do najstarszych miast współczesnej Białorusi. Już w średniowieczu było ono liczącym się ośrodkiem miejskim, w którym kwitło rzemiosło i handel. Początkowo było siedzibą udzielnych książąt ruskich. Potem od lat 70. XIII w. aż do rozbiorów należało do Litwy. Od 1413 roku stanowiło centrum powiatu grodzieńskiego województwa trockiego Wielkiego Księstwa Litewskiego. Lubili przebywać tu Jagiellonowie, Stefan Batory (który życie tu zakończył) oraz Władysław IV Waza. Już w średniowieczu miasto pełniło też ważne funkcje polityczne. Odbywały się tu zjazdy litewskiej rady wielkoksiążęcej i sejmy litewskie, a od 1673 r. sejmy Rzeczypospolitej Obojga Narodów. Fakt ten w sposób znaczący zaważył i wpłynął na rozwój miasta i utrzymanie, mimo zniszczeń wojennych doby „potopu moskiewskiego" i wojny północnej, jego potencjału demograficznego. W II połowie XVIII wieku miasto zostało siedzibą kilku centralnych instytucji litewskich.

Prawa miejskie magdeburskie nadał miastu Aleksander Jagiellończyk w 1496 r. Zostali nim objęci również mieszkańcy kilkunastu osad, zwanych najczęściej wsiami miejskimi lub przedmieściami, założonych przez mieszczan na pokaźnym ok. 400 włókowym obszarze podległyın jurysdykcji magistratu. Choć obszar ten kurczył się, przechodząc we władanie duchowieństwa i szlachty jeszcze pod koniec XVIII wieku jurysdykcji magistratu podlegało 347 dymów położonych we wsiach miejskich.

Chociaż Grodno w czasach nowożytnych zapewne nigdy nie przekroczyło liczby 10 tys. mieszkańców, jednak w warunkach Wielkiego Księstwa Litewskiego, gdzie oprócz Wilna i Mohylewa nie było bardzo dużych miast,

go pocztmajstra bialostockiego jako przyczynek do dziejów mieszczaństwa w XVIII wieku, w: Repatriacje $i$ migracje ludności pogranicza $w X X$ wieku. Stan badań oraz źródla do dziejów pogranicza polsko-litewskiego-bialoruskiego. Materialy konferencyjne dedykowane dr Henrykowi Majeckiemu, red. M. Kietliński, W. Śleszyŕski, Białystok 2004, s. 173-179.

15 P. Borowik, Jurydyki miasta Grodna w XV-XVIII wieku. Stanowy podzial nieruchomości, Supraśl 2005; tenże, Źródla do budżetu miasta stolecznego Jego Królewskiej Mości Grodna w II polowie XVII i w XVIII wieku, w: Repatriacje i migracje ludności pogranicza $w$ XX wieku, s. 166-172; J. Gordziejew, Socjotopografia (irodna w XVIII wieku, Toruń 2002. 
zaliczyć je można do dużych i znaczących ośrodków miejskich. Pod koniec XVIII wieku według lustracji z 1789 r. liczyło ono 1054 dymy, czyli zapewne około 6-7 tys. mieszkańców. Wielkość ta odpowiada zapewne liczbie mieszkańców przed zniszczeniami połowy XVII w.

Jak ogromna większość miast na Litwie również Grodno było zróżnicowane etnicznie i konfesyjnie. Obok Polaków mieszkali tu Rusini, Żydzi, Niemcy, wyznawcy prawosławia (potem unici), rzymscy katolicy, luteranie i wyznawcy religii mojżeszowej ${ }^{16}$.

Testamenty epoki nowożytnej spisywano wedle pewnego schematu ${ }^{17}$. Zazwyczaj składały się one $\mathrm{z}$ następujących części: krótszych lub dłuższych apostrof czy inwokacji; areng, w których testator wyrażał swój stosunek do życia, śmierci czy wieczności; formuły stwierdzającej poczytalność; dyspozycji dotyczących duszy i ciała tj. pogrzebowych; czasem legatów na rzecz instytucji kościelnych lub charytatywnych; następnie dyspozycji majątkowych wraz z wymienieniem długów. W końcowej części zazwyczaj spotykamy się z pożegnaniem i błogosławieństwem dla rodziny, prośbą o wybaczenie krzywd; wyznaczeniem egzekutorów testamentu czy opiekunów dla pozostałych potomków. Testament zazwyczaj zamyka data i podpisy ${ }^{18}$. Od wyżej zaprezentowanego formularza $\mathrm{w}$ zasadzie testamenty mieszczan grodzieńskich nie odbiegają. Według podobnego formularza sporządzono również testamenty mieszczan sieradzkich ${ }^{19}$, pabianickich ${ }^{20}$ i kieleckich ${ }^{21}$. Testamenty mieszczan wojnickich nie mogą stanowić materiału porównawczego. Mimo że we wstępie zaznaczono, że edycja udostępnia pełne teksty testamentów mieszczańskich, pominięto w nich formuły początkowe (inwokację, arengę) i końcowe, również dyspozycje dotyczące duszy, wyjątkowo występują dyspozycje pogrzebowe. Zamieszczone fragmenty testamentów ograniczają się w zasadzie do dyspozycji majątkowych ${ }^{22}$.

16 Wśród najważniejszych pozycji dotyczących dziejów Grodna wymienić należy prace Józefa Jodkowskiego, Przemysława Borowika, Jerzego Gordziejewa i innych. Tamże obszerniejsze bibliografie przedmiotu.

17 B. Groicki, Tytuly prawa magdeburskicgo, s. 190-193. Podaje on gotowe formularze testamentów, na których się wzorowano.

18 A. Karpiński, Zapisy „pobożne”..., s. 213.

19 U. Sowina, op. cit., s. 6.

20 H. Żerek-Kleszcz, op. cit., s. 39-46.

21 J. Główka, op. cit., s. 326-327.

22 Testamenty mieszczan wojnickich..., passim. 
Podobny układ miały testamenty szlacheckie ${ }^{23}$ i włościańskie ${ }^{24}$. Różnice dotyczą kolejności następujących po sobie części, rozbudowania niektórych lub pominięcia.

Warto zwrócić uwagę na różnicę między testamentem i aktem ostatniej woli. Akt ostatniej woli był pojęciem szerszym, obejmującym z formalno-prawnego punktu widzenia różne typy dokumentów m.in. testamenty. Aktem ostatniej woli był więc dokument nazwany przez grodzieńskiego pisarza ławniczego relacją. Mieszczanin grodzieński Stanisław Przyłucki, udając się na dziada do szpitala św. Ducha, a więc niejako żegnając się $\mathrm{z}$ dotychczasowym sposobem życia, rozdysponował nim cały swój majątek. Mimo wyraźnych podobieństw $\mathrm{z}$ formalno-prawnego punktu widzenia dokument ten testamentem jednak nie był (nr 24). W literaturze przedmiotu zwracano już zresztą uwagę na trudność w odróżnieniu testamentu od alienacji w drodze aktów między żyjącymi ${ }^{25}$. Testament małżeństwa Filipowiczów sporządzony w czasie zarazy $\mathrm{z}$ formalno-prawnego punktu widzenia był jedynie obopólną darowizną na wypadek śmierci ${ }^{26}$. Innego rodzaju przykład zeznania ostatniej woli znany jest z Mohylewa. Był to prywatny list, w którym kupiec, będąc $\mathrm{w}$ niewoli moskiewskiej w Smoleńsku i przewidując: rychłą śmierć, nakazywał żonie poczynienie odpowiednich kroków mających go ocalić. Ponieważ nadzieja na wyzwolenie była nikła, dalej list zawiera sformułowania charakterystyczne dla testamentów m.in. dyspozycje majątkowe ${ }^{27}$. Podobnie adytament do testamentu był aktem ostatniej woli - testamentem jednak nie był. Niemal wszystkie podane przykłady opisują akty ostatniej woli powstałe w sytuacjach nadzwyczajnych. Ówczesne prawo przewidywało takie sytuacje, dlatego testamenty czasu zarazy i wojny, sporządzane w sposób niespełniający pełnych wymogów m.in. co do ilości świadków czy też formy

23 A. Borkowska, op. cit., s. 11-17; Testamenty szlachty krakowskiej..., s. XIV; K. Dobrowolski, op. cit., s. 29, zauważa, że testamenty szlacheckie przestały wzorować się na formularzach, wielokrotnie przepisywane lub dyktowane przybierały bardziej indywidualny charakter.

24 K. Dobrowolski, op. cit., s. 17-18, podaje, że w testamentach włościańskich arengę, błogosławieństwo dla dzieci, pożegnanie i przeproszenie oraz wyznaczenie egzekutorów spotyka się sporadycznie. Zauważyć również można, że dyspozycje pogrzebowe ograniczają się zazwyczaj do oddania ciała ziemi, wyjątkowo w przypadkach zamożniejszych włościan są bardziej szcz.egółowe. Można powiedzieć, że w zasadzie zachowały one tradycyjną formę testamentu - rozporządzeń majątkowych.

25 K. Bukowska, op. cit., s. 93.

26 Ibidem, s. 103.

27 I. Марзалюк, Магілёу у XII-XVIII cmcm. Людзі і рэчb, Мінск 1998, s. 121-122. 
sporządzenia, były honorowane ${ }^{28}$. Jak się zdaje prawo, choć zapobiegliwe, nie przewidziało wszystkich takich sytuacji. Zapewne oprócz wymienionych tu form: listu, testamentu, adytamentu, relac.ji, obopólnej darowizny - akty ostatniej woli niekiedy przybierały inne formy. Innymi słowy nie każdy akt ostatniej woli był $\mathrm{z}$ formalno-prawnego punktu widzenia testamentem, chociaż każdy testament był aktem ostatniej woli, choć był testamentem w znaczeniu potocznym, zaś z formalnego punktu widzenia był nim tylko dokument spełniający określone kryteria prawne i formalne.

Podstawą moich rozważań jest analiza 81 aktów ostatniej woli mieszczan grodzieńskich, które powstały w lat ach 1640-1796. Wśród nich 42 pochodzą z XVII w., a 39 z XVIII w. Z okresu wcześniejszego zachował się tỵlko jeden testament - Iwana Siergiejewicza (1485 r.). W większości pochodzą one z ksiąg ławy i rady Grodna, nieliczne odnalazłam w zbiorach wileńskich. Ilość zachowanych testamentów w księgach miejskich grodzieískich można szacować na około 200 może 250 , w tym około $130-150$ to testamenty mieszczan. Odnalezienie wszystkich aktów jest zadaniem bardzo pracochłonnym i z przyczyn oczywistych nie zawsze możliwyın do wykonania. Wydaje mi się jednak, że zbiór osiemdziesięciu, być może trochę przypadkowy, odzwierciedla strukturę testamentów. Ukazuje mieszkańców Grodna, ich mentalność, sposób życia, zajęcia czy stosunki rodzinne. Odnalezienie wszystkich zachowanych $\mathrm{w}$ księgach miejskich testamentów, równie dobrze można nazwać zbiorem przypadkowym. Nie wiemy bowiem jaka część archiwaliów zachowała się do dziś.

W ogromnej większości dokumenty to kopie aktykowane $\mathrm{w}$ księgach miejskich. Oryginałów jest niewiele (nr 38, 39, 43, 45, 54,68) ${ }^{29}$. Trzy z nich pochodzą z XVII. Z niewyjaśnionych przyczyn zostały one wszyte do ksiąg miejskich. Kolejne trzy testamenty udało mi się odnaleźć w zbiorach Litewskiego Paístwowego Archiwum Historycznego w Wilnie. Jeden z nich zachował się tylko we fragmencie. Wszystkie pochodzą z XVIII wieku. Dwa $\mathrm{z}$ tych testamentów znanych jest również skądinąd. Testament Marianny z Paszkiewiczów, żony burmistrza Józefa Badarakiego, został aktykowany w jednej z ksiąg grodzkich grodzieńskich (nr 54) ${ }^{30}$, zaś testament mieszczanina Mateusza Masłowskiego znamy z wypisu z ksiąg miejskich (nr 45) ${ }^{31}$.

28 K. Bukowska, op. cit., s. 94.

29 W nawiasach podano numery testamentów, których wykaz zamieszczono na koícu publikacji.

30 NAHB w Mińsku, F. 1711, op. 1, nr 30, k. 625v 631.

31 LPAH w Wilnie, F. 1282, op. 1, nr 5308. 
Oryginały nie zawierają tytułów. Pięć z nich rozpoczyna się bezpośrednio od inwokacji, jeden od stwierdzenia tożsamości aktora. Formuły aktykacyjne dopisano $\mathrm{z}$ boku, na lewym marginesie. $\mathrm{W}$ jednym przypadku na odwrocie dopisano również, że jest to oryginalny testament, podano personalia testatora oraz datę sporządzenia dokumentu. Kolejnym wyróżnikiem, najbardziej charakterystycznym, są oryginalne podpisy świadków złożone pod dokumentem różnymi charakterami pisma. Oryginały testamentów są więc prawdziwą rzadkością. Nie spotkałam się w artykułach źródłoznaw("ych, z ich wyróżnieniem i oddzielnym omówieniem ${ }^{32}$.

$\mathrm{W}$ przeciwieństwie do innych miast (np. Poznania czy Lwowa) nie istnieją w zachowanym zespole źródłowym oddzielne księgi testamentów ${ }^{33}$. Są one rozproszone wśród innych dokumentów.

\section{Reprezentatywność zbioru}

W zachowanym zbiorze wśród 81 aktów ostatniej woli 52 stanowią testamenty mężczyzn, 29 kobiet, a jeden testament sporządzony wspólnie przez małżonków. Po przeanalizowaniu stanu cywilnego testatorów okazało się, że wśród mężczyzn było: 11 wdowców, 36 żonatych, oraz 5 mężczyzn, których określiłabym jako kawalerów, jednak nie możemy wykluczyć, że byli oni wdowcami, bez potomstwa. Przykładem może być Jan Fondeberg, który czyniąc dyspozycję majątkową, bardzo lakonicznie stwierdzil, że „nikogo już bliższego oprócz brata nie ma" ( $\mathrm{nr} 8$ ). Jeśli zaś chodzi o kobiety proporcje są nieco inne. Na 29 kobiet 17 to wdowy, 12 zaś mężatki, panny w ogóle nie wystąpiły. Analiza stanu cywilnego testatorów wydaje się potwierdzać ustalenia historyków, o częstszym zawieraniu ponownych związków małżeńskich przez mężczyzn, niż kobiety, a przynajmnniej to, iż mężczyźni raczej rzadko pozostawali $w$ stanie wdowim ${ }^{34}$.

Określenie stanu cywilnego w większości przypadków nie sprawiło trudności, mamy bowiem o tym zazwyczaj bezpośrednią wzmiankę (testator określa siebie jako wdowę, wdowca, prosi o pochowanie obok współmałżonka lub jego wyznacza jako wykonawcę dyspozycji pogrzebowych, najczęściej

32 O oryginałach wśród publikowanych testamentów wspomina jedynie M. Borkowska, op. cit., s. 11 .

:33 W. Łoziński, Patrycjat..., s. 12; A. Karpiński, Zapisy „pobożne”..., s. 209.

34 C. Kuklo, Kobieta samotna w spoleczeństwie miejskim u schylku Rzeczypospolitej szlacheckiej, Białystok 1998, s. 103. 
zaś czyni zapis na jego rzecz itp.) lub informacje, które sugerują, do jakiej grupy zaliczyć daną osobę.

W przypadku kawalerów określenie ich stanu ułatwiają dyspozycje majątkowe na rzecz rodziców, brata, sióstr przy jednoczesnym braku adnotacji na temat dzieci czy żony; również młody wiek.

Wśród testatorów 22 dokumenty dotyczą patrycjatu. Podstawą identyfikacji tej grupy było pełnienie funkcji: landwójta, burmistrza, rajcy, lawnika, pisarza rady lub ławy, syndyka miejskiego lub bycie ich żoną. Identyfikacja przeprowadzana na tej podstawie wydaje mi się słuszna. Jednakże, jeśli potraktować patrycjat jako elitę miasta, to niepokój budzi przypadek pisarza Pawła Worobieja (nr 10) ${ }^{35}$.

.Jeśli chodzi o strukturę wyznaniową testatorów, próbowałam ją określić na podstawie bezpośrednich deklaracji, miejsca pochówku, czy też innych okoliczności (np. syn był jezuitą, pensjonariusz szpitala Św. Ducha). Nie we wszystkich jednak przypadkach było to możliwe. Dziewięć testamentów, to tylko dyspozycje majątkowe, w kolejnych brak wskazania miejsca pochówku lub jakichkolwiek innych wzmianek, które identyfikację by umożliwiały.

Autorzy testamentów to jednak w większej części katolicy (60), unitów było niewielu (4), jedna osoba wyznania luterańskiego oraz 16 osób, których identyfikacja na podstawie testamentów jest niemożliwa. Fakt, iż ogromna większość zachowanych dokumentów to testamenty rzymskich katolików, nie wydaje się w żaden sposób zmniejszać wartości zbioru. Jest on, jak się wydaje, reprezentatywny i odzwierciedla strukturę wyznaniową społeczeństwa Grodna. Spośród 81 testatorów 40 mieszkało w Grodnie, 4 w jego lewobrzeżnej części, zwanej Przedmieściem Zaniemeńskim, 30 we wsiach miejskich, $45 \mathrm{z}$ nich mieszkało na terenie parafii farnej, 29 na obszarze parafii zaniemeńskiej. Miejsca zamieszkania 7 nie udało się określić.

\section{Sposób wpisu do ksiąg miejskich}

Wszystkie testamenty sporządzono i wpisano do ksiąg miejskich w języku polskim. Wyjątkiem jest późnośredniowieczny dokument Iwana Siergiejewicza sporządzony w języku kancelaryjnym Wielkiego Księstwa Litewskiego (nr 1).

35 Jak wynika z testamentu człowiek ten, mimo że pełnił funkc.ję pisarza wójtowskiego i ławniczego nie znajdował się w najlepszym położeniu materialnym. Sam stwierdził, że małżonka jego nie będzie miała za co pogrzebu sprawić, prosił tė o darowanie długów. 
Wpisy w księgach miejskich rozpoczynają się od tytułu, wyraźnie oddzielonego od całości. Opatrywano nimi testamenty dopiero w momencie wpisania do akt. Oryginały, jak wspomniano wyżej, ich nie posiadały, wyraźnie natomiast wydzielano w nich inwokację. W 68 przypadkach $\mathrm{w}$ tytułach wyraźnie zaznaczono słowo „testament”. Najczęściej oprócz personaliów niczego więcej nie podawano np. Testament Kaspra Bogdanowicza (nr 5), Testament Pani Masnickiej (nr 12). Tytuły niekiedy zawierały określenie funkcji lub zawodu testatora. W XVIII wieku zasadą stało się podawanie personaliów w pełnym brzmieniu oraz używanie terminu aktykacja. Coraz częściej zaznaczano, iż testator w momencie podawania dokumentu do akt nie żył. W nagłówkach zaznaczano również osoby, na których rzecz sporządzony został testament, np. Aktykacja testamentu zeszlego z tego świata Romana Makara Romanowej Makarowej i potomstwu jej slużqcego (nr 49). W kilku innych przypadkach dyspozycje ostatniej woli wpisano do ksiąg miejskich pod następującymi tytułami: Zeznanie Dispositiej Pani Lagowskiej przez Pana Adamowicza (nr 6), Relacja P. Adamowicza Ostatniej Dispositiy P. Karlowskiey (nr 11), Dispozycja P. Przeluckiego (nr 24). W dwóch przypadkach są to Punkty testamentowe (nr 74, 75) oraz Addytament do testamentu ( $\mathrm{nr} 80$ ).

Po tytule następowała zazwyczaj formuła aktykacyjna, w której wymieniano osoby zeznające, podające, przedkładające testamenty przed urzędem miejskim. Następnie imię i nazwisko testatora, sprawowaną funkcje lub zawód, w przypadku kobiet również nazwisko panieńskie. Chociaż formuły aktykacyjne nie stanowiły integralnej części testamentu, często jednak zawierały one ważne informacje nie znane $\mathrm{z}$ treści testamentu, ani innych źródeł.

Akty ostatniej woli pochodzące $\mathrm{z}$ lat $1640-1676$ do akt podawali ławnicy $^{36}$. W ogromnej większości zeznawali ich treść ci sami urzędnicy, którzy obecni byli przy ich sporządzaniu. W nielicznych przypadkach byli to ławnicy, którzy przy zeznaniu ostatniej woli obecni nie byli $(\mathrm{nr} 11,12)$. Począwszy od lat 90. XVII wieku można zaobserwować w tym względzie wyraźną różnicę. Przed urzędem miejskim stawali, by podać zeznania ostatniej woli, niemal wyłącznie członkowie rodziny testatora, osoby bezpośrednio zainteresowane spadkiem. 12 razy byli to współmałżonkowie. W przypadku wdów tylko raz odnotowano, że stanęła przed urzędem miejskim w asyście opiekunów (nr 72). W innych przypadkach były to: najczęściej dorosłe dzieci,

36 Ze względu na różny sposób podania do akt miejskich i sporządzenia wyodrębniłam testamenty sporządzone w latach 1640-1676 oraz 1689-1796. 
znacznie rzadziej rodzeństwo lub dalsi krewni. Niekiedy stopień pokrewieństwa zeznającego $\mathrm{z}$ testatorem jest trudny do ustalenia ( $\mathrm{nr} 44,63,68)$. Bardzo rzadko testament podawali do akt wyznaczeni opiekunowie lub adwokaci $(\mathrm{nr} 65,66)^{37}$.

\section{Sporządzenie testamentu}

Testainenty, które omawiam, wyda ją się być zbiorem dość różnorodnym. Większość z nich została sporządzona w sytuacji typowej, najczęściej krótko przed śmiercią, o czym świadczą daty aktykacji i wzmianki sannych autorów. Zazwyczaj stwierdzał on wyraźnie, że jest chory i bliski śmierci; z takimi twierdzeniami spotykamy się bowiem w 65 przypadkach. Trzy testamenty zostały sporządzone w sytuacji nietypowej. Śmiało jednak możemy ją uznać za zagrażającą życiu. Jeśli zaś porównamy daty sporządzenia dokumentu $\mathrm{z}$ datami aktykacji, to okaże się, że ze $\mathrm{z}$ ich spisaniem czekano prawie do ostatniej chwili.

Wśród powodów sporządzania testamentów sami autorzy najczęściej podają: „aby na potym rostyrków i nienawiści między niemi nie było po śmierci mojej” (nr 46) lub „aby między nikim żadnej nie było różnice” (nr 50). Najważniejszą przyczyną wydaje się więc być podział majątku pomiędzy spadkobierców, tak, aby nikt nie został pokrzywdzony. Miało to $\mathrm{w}$ przyszłości zapobiec kłótniom i konfliktom. Wśród innych powodów można wymienić: troskę o zabezpieczenie żony, wyznaczenie spadkobierców spośród dalszych członków rodziny, przekazanie funduszy na cele religijne i charytatywne ${ }^{38}$. Jednym zdaniem, testator w obliczu zbliżającej się śmierci, chciał uporządkować wszystkie sprawy związane $\mathrm{z}$ doczesnym życieın. W jednym tylko przypadku powodem sporządzenia testamentu była wola spędzenia reszty swego życia w szpitalu (nr 24).

Testamenty mieszczan grodzieńskich były rozporządzeniami ostatniej woli zeznawanymi przed urzędem wójtowsko-ławniczym. Określił to przywilej Bony z 1541 r., w którym królowa nakazała ,żeby testamenta same przed wójtem i ławnikami sprawowane były i do ksiąg miejskich spraw pilnie i wiernie spisywane" ${ }^{39}$.

37 М. Гарлзесу, Н. Сліж, ор. cit., s. 91, podają, że testamenty szlacheckie najczęściej przedkładała również rodzina.

38 B. Groicki, Artykuly prawa magdeburskiego, s. 81; H. Żerek-Kleszcz, op. cit., s. 37.

39 AVAK, T. VII, Wilno 1874, cz. II A, nr 12, s. 76. 
Za typowy wypadało by téz uznać testament sporządzony w domu, w 51 bowiem przypadkach mamy o tym wyraźną informację.

Akty ostatniej woli z lat 1640 1676 sporządzano w obecności lawników wyznac\%onych z urzędu. W 19 przypadkach obecnych było dwóch ławników. 3 razy trzech i 3 razy jeden. Nie przestrzegano jednak ściśle tej zasady. I tak obok lawników przy sporządzaniu ostatniej woli w trzech przypadkach obecny był przedstawiciel urzędu radzieckiego (nr 18, 20, 32). Testamenty zaś rajcy Mikołaja Gudajewskiego i lawnika Aleksandra Karłowskiego sporządzono w obecności dwóch lawników i dwóch rajców (nr 19, 22) ${ }^{40}$.

Przy sporządzaniu testamentu obecne też były inne osoby: sąsiedzi, których wymieniano kolejno $\mathrm{z}$ imienia i nazwiska lub poprzestawano na stwierdzeniu ich obecności, bez wskazania liczby; często rodzina; przedstawiciele cechów (jeśli testator był ich członkiem lub była to wdowa po mistrzu); bardzo rzadko (w dwóch przypadkach) duchownych. W jednym zaś $\mathrm{z}$ testamentów odnotowano, że sporządzony został: „Przy całej wsi [miejskiej] Małachowiczach mężach i sąsiadach..." (nr 19).

Wśród dokumentów pochodzących $\mathrm{z}$ tego okresu wyróżniłam siedem dyspozycji ostatniej woli pochodzących z lat 1657-1660. Ich sposób sporządzenia bowiem wyraźnie odbiega od przedstawionej powyżej zasady. Trzy z nich pochodzą z 1657 r. Dorota Łagowska ${ }^{41}$. zeznając swoja wolę przed burmistrzem, wyraźnie uzasadniła, że uczyniła to „w niedostatku natenczas urzędu wójtowskiego grassante hostilitat" (nr 6). Podobnie Krystyna Filipowiczowa „nie mając, na ten czas przed kim by ostatnią wolę swoję opowiedziała" uczyniła to, biorąc za świadka .Jędrzeja Gruszczyńskiego namiestnika grodzieńskiego ( $\mathrm{nr} 7$ ). Z kolei Jan Fondeberk, „będąc chorobą po-

40 Mieszczanie sieradzcy składali swoje zeznania przed urzędem ławniczym, w dwóch przypadkach radzieckim, a w trzech członkowie rady i ławy wystąpili łąc:znie (U. Sowina, op. cit., s. 20-21). Testamenty mieszczan pabianickich z lat $1617-1718 \mathrm{w}$ większości sporządzono w domu w czasie choroby. Były one również ustnymi zeznaniami ostatniej woli składanymi przed urzędem miejskim w obecności 2 lub 3 przedstawirieli rady lub rady i ławy. Znacznie częściej zeznawano wiec je przed członkami urzędu radzieckiego (H. Żerek-Kleszcz, op. cit., s. 38). Podobnie w domu w obecności urzędników miejskich sporządzono testamenty nieszczan kieleckich z lat 1790-1791 (J. Główka, op. cit., s. 326). Testamenty mieszczan wojnickich $\mathrm{z}$ lat 1599-1809 również sporządzano i zeznawano do ksiąg miejskich przed urzędem radzieckim (Testamenty mieszczan wojnickich..., opr. P. Dymmel, s. 12). Pisze o tym (iroicki (Tytuly prawa magdeburskiego, s. 77) twierdząc, iż zasada prawa magdeburskiego, która nakazywała sporządzanie testamentów w obecności 7 świadków nie była stosowana i znacznie częściej powstawał on w obecności urzędników miejskich, co uznawano za znacznie bezpieczniejsze.

41 W przypadku kobiet ograniczyłam się do podawania w tekście imienia i nazwiska (w przypadku kilkukrotnie zamężnych, po ostatnim mężu), pełne personalia odnajdzie czytelnik w wykazie testamentów zamieszczonym na konicu. 
wietrza morowe[g]o zarażony" zeznał swoją wolę przed Aleksandrem Michalem Moszczyńskim podstarościm chodorowskim (nr 8). Dyspozycje te można określić mianem testamentu czasu zarazy (testamentum pestis tempore) ${ }^{42}$. Były to krótkie, pozbawione jakichkolwiek, inwokacji, areng czy formuł pożegnalnych, przedśmiertne dyspozycje majątkowe. Jedynie Jan Fondeberg wspomina o pogrzebaniu swego ciała, nie mając w tym względzie żadnych, że tak powiem życzeń, prosi bowiem, „aby ciało moje grzeszne jakkolwiek zakopane było". 'Troska o zbawienie wyrażona została jednym zdaniem, by spadkobierca pamiętał o jego duszy (nr 9). Dla ważności i wiarygodności testamentu czasu zarazy wymagano obecności przynajınniej dwóch świadków, którzy zobowiązani byli zeznać jego treść przed sądem ${ }^{43}$. We wszystkich zaś trzech omawianych przypadkach zeznanie miało miejsce w obecności jednego.

Kolejne cztery testamenty sporządzono w obecności: ławnika - testament Jana Chackiewicza Wołka (nr 9); ławnika i rajcy - Pawła Worobieja (nr 10); rajcy - Katarzyny Karłowskiej (nr 11) i Jadwigi Massnickiej (nr 12). Ich nietypowość można wytłumaczyć wydarzeniami polityczno-społecznymi. W sierpniu bowiem 1655 r. Moskwa zajęła miasto, które okupowała do marca 1659 roku. Powtórnie zdobył miasto Iwan Chowański w grudniu 1659 roku. Polakom dało się je odbić we wrześniu 1660 roku. Niewielka załoga moskiewska utrzymała się jednak $w$ zamku aż do marca roku następnego $^{44}$. Wszystkie testamenty pochodzące $\mathrm{z}$ lat $1657-1660$ powstały $w$ sytuacji wyjątkowej, podczas „potopu moskiewskiego" i zarazy. W okresie, gdy urząd wójtowski nie funkcjonowal, wielı urzędników miejskich bądź wyjechało $\mathrm{z}$ miasta, bądź zmarło. Wówczas nie możliwe było przestrzeganie zasad, które obowiązywały w czasie pokoju. W każdym jednak razie przy

42 Trzy takie dyspozycje wyróżniono również wśród testamentów mieszczan pabianickich. Zeznane one zostały zgodnie z przepisami w obecności dwóch świadków (H. Żerek-Kleszcz, op. cit., s. 39). W literaturze podkreślano, że w czasach szczególnego zagrożenia ilość takowych dyspozycji wyraźnie wzrasta. Wśród 26 testamentów mieszczan sieradzkich sporządzonych w latach 1500-1536 - osiem pochodzi z roku 1507 (dwóch miesięcy), w którym najprawdopodobniej szerzyła się w mieście zaraza. (U. Sowina, op. cit., s. 9). Również S. Hołdys (op. cit., s. 348) wspomina, że w czasach zarazy wzrasta ilość sporządzanych testamentów, nie podaje jednak żadnych przykładów.

43 K. Bukowska, op. cit., s. 94.

44 A. D. Skorobohaty, Diariusz, opr. T. Wasilewski, Warszawa 2000, s. 65, 74; J. A. Chrapowicki, Diariusz. Część pierwsza: lata 1656-1664, oprac. T. Wasilewski, Warszawa 1978, s. 263-5, 284; С. Данскіх, Гроджа у гады руска-польскай вайжы 1654-1667 г2., w: Пактьь. Гисторька-далументальная хроніка горада Гродка, Мінск 1999, s. 83; А. Госцеу, В. ІІІвед, Кронан. Летапіс Горада на Нёмане (1116-1990 г2.), Гродна 1993, s. 30; NAHB w Mińsku, F. 1800, op. 1, nr 1, k. 27. 
rozporządzeniu ostatniej woli obecna była przynajmniej jedna osoba urzędowa.

Wydaje się, że zasadą było sporządzanie testamentu w obecności dwóch ławników. $\mathrm{W}$ praktyce jednak stosowano $\mathrm{z}$ różnych powodów odstępstwa od niej. Zapewne zasada ta wywodzi się z podziału miasta na nac.je. Grodno, podobnie jak wiele miast Wielkiego Księstwa Litewskiego obdarzonych prawem magdeburskim w czasach Aleksandra Jagiellończyka dzieliło się nacje: litewską (katolicką) i ruską (prawosławną a potem unicką). Stosowana była swoista równowaga między obiema społecznościami. Corocznie więc z grona rajców wybierano dwóch burmistrzów: litewskiego i ruskiego. Pieczęcią miejską (radziecką) pieczętował burmistrz litewski. Klucze od skrzyni z pieczęcią i aktami miejskimi miał wójt, burmistrz ruski i rajca litewski ${ }^{45}$. Zapewne, ustalony jako typowy, udział przy sporządzeniu testamentów dwóch lawników odzwierciedlał to zróżnicowanie. W połowie XVII wieku, jak się wydaje, podział na nacje był jednak już tylko anachronizmem. W przypadku sporządzania testamentów zwyczaj jednak przetrwal prawie do końca wieku.

W omawianych dokumentach, pochodzących z lat 1689-1796, można zaobserwować wyraźną różnicę. Zadecydowanie odstąpiono od zasady sporządzania ich w obecności dwóch lawników. Osobą najczęściej pojawiającą się w roli urzędowego świadka był pisarz. Ich podpisy widnieją w 27 na 42 analizowane przypadki, 15 razy pojawił się podpis pisarza wójtowskiego, 12 radzieckiego. Wśród innych świadków testamentu wymienić można: trzykrotnie lawników (w dwóch przypadkach 1 i raz 2), w jednyın przypadku landwójta i raz księdza. Znacznie częściej pojawiali się przedstawiciele urzędu radzieckiego: burmistrz i rajca, najczęściej oddzielnie jako pojedynczy świadkowie, trzykrotnie zaś wspólnie, przy czym: wiarygodność zapisu burmistrza Władysława Dorzbacha wyjątkowo potwierdzili dwaj burmistrzowie i rajca (nr 46). W testamencie Ludwika Laffaye pojawia się już nazwa prezydenta zamiast burmistrza ( $\mathrm{nr} 77$ ). W roli świadków, obok urzędników miejskich, bardzo często pojawiają się osoby, które nie sprawowały urzędowych funkcji, a przynajmniej tego nie odnotowano, zapewne sąsiedzi lub osoby $\mathrm{w}$ jakiś inny sposób związane $\mathrm{z}$ osobą autora testamentu. Na podstawie zachowanych archiwaliów nie da się niestety tego ustalić. W siedmiu omawianych przypadkach ich podpisy lub potwierdzenia wiarygodności odznaczono tylko za pomocą krzyżyków. Wypadało by również zaznaczyć, że $\mathrm{w}$ testamentach $\mathrm{z}$ tego okresu świadkowie określani byli mianem pieczęta-

45 AVAK, t. VII, cz. II A, nr 12, s. 76. 
rzy. 'Tymczasem pisarze, wpisujący do ksiąg miejskich treść testamentów, opisujący dokładnie czyje i w jaki sposób złożone podpisy pod nim widnieją, o pieczęciach wspominają tylko w wy jątkowo (nr $8,73,77,78)$.

Wiarygodność testamentu potwierdzali obecni świadkowie. Jeśli autor był człowiekiem piśmiennym, sam go podpisywal, co wyraźnie było stwierdzane. Jeśli nie potrafił pisać poświadczenie następowało „za daniem ręki panom ławnikom" (nr 28). Czasami spotykamy się i z jednym i drugim sposobem, czyli podpisem testatora i stwierdzeniem jego wiarygodności poprzez uścisk dłoni. Mniemać można, że w testamenta.ch, w których wyraźnie o tym nie wspomniano uścisk dłoni był również elementem zwyczajowo potwierdzającym testament.

W testamentach XVIII-wiecznych niepiśmienni testatorzy stawiali krzyżyki, początkowo jeden, później coraz częściej trzy, czego nie spotyka się w dokumentach z XVII wieku. W dalszej kolejności następowały podpisy obecnych świadków. Zauważyć należy, że w XVII wieku nie wszyscy obecni, wymienieni zazwyczaj na początku dokumentu, potwierdzali jego wiarygodność podpisem. Zrozumiałe wydaje się to w przypadku wielu obecnych zazwyczaj osób niepiśmiennych np. członków rodziny czy sąsiadów. Podpisów nie składali jednak często również urzędnicy miejscy. W związku z tym świadków testamentu można by podzielić, na tych, którzy byli tylko obecni (zazwyczaj było ich oczywiście więcej) i urzędowych świadków, czyli tych, którzy testament za pomocą własnych podpisów stwierdzali. W XVII w. byli to niemal wyłącznie lawnicy. Rajcy obecni przy sporządzaniu testamentu nie podpisywali się (nr 18, 20,22). Do wyjątków należą testamenty, które opatrzone zostały dodatkowo podpisami innych świadków, np. przedstawicieli urzędu radzieckiego. Z takimi przypadkami spotykamy się wówczas, gdy autor był osobą sprawującą wysokic funkcje miejskie, np. burmistrza (nr 32) lub rozporządzenie ostatniej woli nie do końca zgodne było $\mathrm{z}$ obowiązującymi przepisami prawa spadkowego. Mikołaj Gudajewski, wydziedziczył syna ${ }^{46}$, uzasadniając taką dyspozycje niemoralnym i nagannym zachowaniem. Majątek swój przekazał landwójtowi grodzieńskiemu Hanusowi Paulsenowi (nr 19).

Podział na świadków obecnych i urzędowo stwierdzających podpisem wiarygodność ostatniej woli zaciera się zupełnie w wieku XVIII. Zrezygno-

46 A. Brïckner (Slownik etymologiczny języka polskiego, Warszawa 2000, wyd. IX) jednoznacznie podaje określenie synowiec jako syn, s. 528; Groicki (Artykuly prawa magdeburskiego, s. 5) pisząc o dziedziczeniu w linii bocznej wymienia w jednej linii synowców i siostrzeńców. Sugeruje to, że synowcy to synowie brata, tak jak siostrzeńcy siostry. 
wano wówczas $\mathrm{w}$ ogromnej większości przypadków $\mathrm{z}$ wymieniania na początku obecnych, ograniczając się jedynie na końcu do wymienienia tych, którzy mieli swoje podpisy złożyć. Najczęściej prośba o podpisy wyrażona była w sposób ogólnikowy i skierowana do „szlachetnych panów urzędników miasta JKM Grodna" lub „panów pieczętarzów” proszonych o podpis (nr 47, 48, $49 \mathrm{i}$ in.). Interesujące $\mathrm{z}$ tego względu są dwa testamenty pochodzące z początku XVIII wieku. Bartłomiej Pawel Ćwikła pisarz radziecki, kończąc swoje zeznanie poprosił o podpisy: landwójta, obu burmistrzów oraz ławnika - Jana Markiewicza. Pod testamentem złożył jednak swój podpis tylko burmistrz (nr 44). Można więc domniemywać, że proszeni o podpisy nie byli obecni podczas sporządzania dokumentu. Podobnie Władysław Dorzbach (nr 46) sporządzając swój testament, wyjątkowo jak na testamenty z XVIII wieku, wymienił na początku z imienia i nazwiska obecnych trzech sąsiadów, zaznaczył również, że obecna była niemal cała rodzina, ale na końcu o podpisy poprosił burmistrzów - Jana Rozumowicza i Jana Meystra oraz dwóch rajców. Podpisy jednak złożyli: rajca oraz dwaj burmistrzowie: Jan Meyster i Michał Kolęda. Nie można tu założyć, że testator pomylił się określając Jana Rozumowicza tytułem burmistrza. Był on rajcą i byłyın burmistrzem, musiał więc wiedzieć, kto pełnił tę funkcję. Testament najprawdopodobniej powstał wcześniej, w okresie gdy sprawował ją Jan Rozumowicz, a o podpisy postarano się później, stąd podpis innego burmistrza Michała Kolędy. Wydaje się, że oba testamenty sporządzili własnoręcznie w sytuacji wyjątkowej w czasie wojny północnej i panującej zarazy sami testatorzy.

Znacznie rzadziej autorzy zeznawali ostatnią wolę w domu sądowym. Wtedy testament sporządzał pisarz w obecności członków ławy i rady. Wśród omawianego zbioru można wyróżnić 4 takie dokumenty. Jasno się w nich stwierdza, że testator osobiście stanął przed urzędem. Zapewne jego zeznanie spisywane było na bieżąco i wpisywane do ksiąg miejskich, stąd jedna data, sporządzenia testamentu i jego wpisania ( $\mathrm{nr} 2,24)$. Wypada jednak zaznaczyć, że w dwóch przypadkach, autorzy stawili się osobiście przed urzędem miejskim, by zeznać testament, ale daty wpisu do ksiąg miejskich i sporządzenia dokumentu różnią się jednak o jeden dzień (nr 65, 78). Testamenty zostały wiec zapewne sporządzone wcześniej i następnego dnia osobiście przez testatorów aktykowane. W przypadku Johana Gotliba Gumscha, wyraźnie zaznaczono, że „ostateczne rozrządzenie testamentowe przez siebie uczynione do akt podal" ( $\mathrm{nr}$ 78). W testamencie jednak Anastazji Pietkiewiczowej dwa razy odnotowano, że zeznanie ostatniej woli miało ustny charakter. Oba testamenty możemy potraktować, jako zeznania ostatniej 
woli uczynione przed urzędem miejskim lub jako testamenty, które osobiście aktykowane były do akt ${ }^{47}$. Zazwyczaj jednak aktykac.ji dokonywano po śmierci testatora, dopiero bowiem wówczas testament nabieral mocy prawnej. Wyjątkowym przykładem jest testament rajczyni Maryny Fandeberkowej. Został on spisany i aktykowany tego samego dnia. W formule aktykacyjnej jednoznacznie określono testatorkę jako osobę zmarłą. Jednak owa rzekoma nieboszczka trzy dni potem wezwała ponownie urzędników do swego domu, by swój testament nieco uzupełnić. Jak to wytłumaczyć? Być może przyczyną była po prostu pomyłka pisarza, który odruchowo w formułce określił testatorkę błędnie jako zmarłą? Przykład ten pozbawia nas jednak pewności, czy pozostałe testamenty aktykowano koniecznie dopiero po śmierci testatorów. Wątpliwości te dotyczą testamentów, w których od daty sporządzenia do momentu aktykac.ji upłynęło niewiele czasu ${ }^{48}$.

Możemy się domyślać, że istniał też inny sposób sporządzania testamentu, tj. sporządzany „pokątnie”. Wzmiankuje o tym przywilej Bony z 1541 ro$\mathrm{ku}^{49}$. Zapewne był on sporządzany bez obecności przedstawicieli urzędowych i nigdy ich nie aktykowano ${ }^{50}$.

\section{Struktura testamentu}

Właściwy testament rozpoczynał się zazwyczaj od inwokacji. Występuje ona poza jednym wyjątkiem w języku polskim (nr 10). W 42 aktach z XVII wieku, pojawia się ona jednak zaledwie w 21 przypadkach, czyli w co drugim testamencie. W 39 testamentach z XVIII w. inwokacja pojawia się już 31 razy. Zapisywano ją w dwóch podobnych formach, a w osiemnastym stuleciu uzupełniano o słowa, które były wyrazem poddania się woli i opiece boskiej ${ }^{51}$.

47 Przyjmowano testanıenty osób żyjących, jeśli sami się z nimi zgłaszali (Testamenty szlachty krakowskiej..., s. XIII).

48 Daty sporządzenia testamentów i aktykacji podano $w$ tabeli zamieszczonej na końcu.

49 AVAK, T. VII, Wilno 1874, cz. II A, nr 12, s. 76.

50 Problem ten wzmiankuje S. Hołdys, (op. cit., s. 352), ale również na podstawie swoich przypuszczeri.

51 W 26 testamentach sieradzkich inwokac.ję zamieszczono 11 razy (U. Sowina, op. cit., s. 7). O inwokacjach nie wspomina H. Żerek-Kleszcz. (op. cit., passim). Czy w takim razie $w$ ogóle nie wystąpiły $w$ testamentach pabianickich? $W$ trzech analizowanych testamentach mieszczan kieleckich z lat 1790-1791 trzy razy wystąpiła inwokacja lacińska (J. Główka, op. cit., s. 326). 
Następnie występowała arenga, w której testator wypowiadał się na temat marności, kruchości życia ludzkiego, konieczności pogodzenia się z chorobą, kończąc zazwyczaj rozważania stwierdzeniem o nieuchronności śmierci. W testamentach XVII-wiecznych pojawiła się ona 18 ra\%y, przy czym należy zaznaczyć, że w I połowie tegoż wieku ograniczała się ona zazwyczaj do jednego zdania. Arengi, mimo że pod względem semantycznym nie różniły się, nie były jednak identyczne ${ }^{52}$. W drugiej połowie XVII w. coraz częściej tego typu rozważania występują w nieco rozbudowanej formie: „W skazitelnym ciele każdy człowiek żyjąc, po długim czasie wyrokowi boskiemu dosyć uczynić powinien będzie, a z tego świat ustąpić musi..." (nr 29). Osiemnastowieczne zapisy tego typu były jeszcze bardziej rozbudowane, a częstotliwość ich występowania wyraźnie wzrasta ${ }^{53}$. W 17 testamentach zastosowano dwa identyczne niemal formularze. $W$ pozostałych przypadkach rozważania występują w różnej formie, nie odbiegając jednak zbytnio od tematyki. W niektórych testamentach, choć należy uznać to za rzadkość, arenga zapisana była w nietypowy sposób, przybiera jąc tym samym indywidualną - być może autorską formę.

Stwierdzenie poczytalności umieszczano zazwyczaj w następnej kolejności lub włączano w tok rozważań egzystencjalnych. „Będąc chorobą od Boga Wszechmogącego nawiedzona, acz na ciel chora, ale na umyśle dobrze zdrowa” ( $\mathrm{nr}$ 2) lub „na ciele chorobą nawiedzona, lecz przy zupełnym zostająca rozumie i pamięci" (nr 23). W sytuacji braku inwokacji i arengi umieszczano je bezpośrednio na początku dokumentu ${ }^{54}$. Trzy razy pojawia się na końcu testamentu. Teresa Wołkowa kończąc zeznanie,

52 Identyczny cytat podaje z testamentów sieradzkich U. Sowina (op. cit., s. 10). Podobne rozważania zanieszczono również w 5 innych sieradzkich testamentach. Nieliczne téz testamenty mieszczan pabianickich zawierają tego typu rozważania - 3 przykłady (H. Żerek-Kleszcz, op. cit., s. 40). W każdym z trzech osiemnastowiecznych testamentów kieleckich wystąpiła arenga (J. Gówka, op. cit., s. 326).

53 O. Hedemann (op. cit., s. 11) zauważa, że długie arengi, (zęsto w ,stylu kwiecistym” powstają od połowy XVIII w., „będąc po części wyrazem z jednej strony płytkiej i ckliwej bigoterii, tak wzmożonej za Sasów, z drugiej zaś odzwierciedlając prądy literackie - panoszenie się i zachwaszczanie języka łaciną oraz barokowością stylu". Testamenty grodzicńskie dostarczają prıykładów, że długie wstępy religijne zaczęły powstawać już w pierwszej połowie XVIII ( $\mathrm{nr} 44$ z $1710 \mathrm{r}$. lub $\mathrm{nr} 48$ - z 1724 r). Zauważyć należy również, że łacina występuje w nich wyjątkowo.

54 We wszystkich 26 testamentach sieradzkich wystąpiła formuła stwierdzająca po(zytalność (U. Sowina, op. cit., s. 9). Nie wiadomo natomiast w ilu testamentach mieszczan pabianickich. Autorka podaje tylko, że większość rozpoczyna się od formuły stwierdzającej poczytalność (H. Żerek-Kleszcz, op. cit., s. 40). Nie porusza tego tematu J. Główka (op. cit., passim). 
dodała tylko, iż uczyniła dyspozycję przy „dobrej refleksji” (nr 51). Dwa razy zapisano ją dwukrotnie, $w$ formule urzędowej i następnie powtórzonej jeszcze raz przez autora (nr 20, 21). W 22 wypadkach jej jednak nie odnotowano. Nie wynika to też, np. z nieobecności osoby urzędowej przy sporządzaniu testamentu. Wśród bowiem 9 aktów ostatniej woli, w których pisarz radziecki Mikołaj Michał Szarkowski występował jako świadek i zapewne to on spisywal testament, formuła o poczytalności nie została odnotowana aż 4 razy. Podobnie pisarz - Jan Kazimierzowicz (aczkolwiek ten był bardziej uważny), nie odnotował formuły 2 razy na 8 testamentów, pod którymi się podpisał. Brak jej również np. w testamencie Bartłomieja Pawła Ćwikły - pisarza radzieckiego. Ten ostatni co prawda nie zaznaczył, że jest chory, i być może wówczas nie konieczne było stwierdzenie poczytalności. Nie wystąpiła ona także w testamentach osób, które wyraźnie mówiły o złym stanie zdrowia. Jedynym wytłumaczeniem może być nieświadomie pominięcie formuły o poczytalności, skądinąd bardzo ważnej $\mathrm{i}$ istotnej55.

Rozporządzenia dotyczące duszy i ciała stanowiły następną część testamentu. W pierwszej kolejności następowało polecenie duszy. W 17 aktach ostatniej woli pominięto tę część formularza ${ }^{56}$. Najbardziej charakterystycznym elementem, najczęściej powtarzającym się jest polecenie duszy nieogarnionemu miłosierdziu pańskiemu lub boskiemu. Oprócz Boga określanego jako: Najwyższy, Wszechmogący, Jedyny, Pan i Twórca najpierw sporadycznie, by w końcu przejść w regułę, pojawia się postać Matki Boskiej: Bogurodzicy, Matki Zbawiciela, Panny Przenajświętszej. O wstawiennictwo coraz częściej proszeni byli również Wszyscy Święci. W XVIII wieku pojawiła się postać Chrystusa Zbawiciela, Odkupiciela, Anioła Stróża, Aniołów Archaniołów oraz konkretnych świętych ${ }^{57}$. Tym samym formułę polecenia duszy coraz bardziej rozbudowywano. Liczny panteon osób boskich, aniołów, patronów proszony był o wstawiennictwo. Polecenie duszy połączone było najczęściej z prośbą o osądzenie i wybaczenie win i grzechów. Porównując testamenty, które najprawdopodobniej spisane zostały przez tę samą osobę, można zauważyć pewne upodobanie do konkretnych

55 B. Groicki, Tytuly prawa magdeburskiego, s. 184, 190.

$56 \mathrm{~W}$ większości są to rozporządzenia wyłącznie majątkowe, również testamenty czasu zarazy i akty ostatniej woli, które spisane zostały w postaci punktów.

57 Polecenie duszy ze wskazaniem konkretnego świętego w testamentach z XVII wieku pojawiło się wyjątkowo (nr 2,32), chociaż ogólnikowe odwołanie się do patronów i patronek jest częste. 
formuł polecających duszę, które są bardzo podobne, czasami nieznacznie modyfikowane ${ }^{58}$.

Dyspozycje pogrzebowe to kolejna część testamentów. Pominięto je w 9 dokumentach analizowanego zbioru, które dotyczyły wyłącznie spraw majątkowych ( $\mathrm{nr} 6,7,8,11,24,27,43,57,80)$. W dwóch przypadkach życzenia co do pochówku sformułowane zostały jedynie w formie stereotypowego: „Ciało moje grzeszne $\mathrm{z}$ ziemi sformowane, ziemi oddaje, aby było pochowane" ( $\mathrm{nr} 79$, podobnie $\mathrm{nr} 23)^{59}$. W dziewięciu innych w nieco rozszerzonej formie ( $\mathrm{nr} 18$, podobnie $\mathrm{nr} 17,25,29,46,61,78,70$ ). W pozostałych przypadkach dyspozycje pogrzebowe, choć nieco bardziej rozbudowane, nie były jednak szczegółowe. Testator zazwyczaj wyznaczał osobę, która miała się zająć oprawą pogrzebu. $\mathrm{Z}$ reguły był to współmałżonek, potomstwo, inni krewni, chociaż czasem również ludzie nie spokrewnieni, mimo iż umierający bliską rodzinę posiadał. Wskazywano też miejsce pochówku, wyznaczano określoną sumę czy inne fundusze przeznaczone na ceremonię pogrzebową. W XVII wieku jedynym dodatkowym życzeniem były prośby o Msze Święte. W XVIII w. dyspozycje pogrzebowe stają się bardziej szczegółowe. Obejmowały one: kondukt, procesję, świece, proszono również aby ceremonie odbyły się z „dzwonieniem po kościołach i Mszami Świętymi” (nr 54). Najczęściej życzenia takie dotyczyły dzwonienia $w$ dwóch lub trzech kościołach, czasami w pięciu, wyjątkowo we wszystkich. Msze Święte odprawiane miały być zarówno za zmarłego autora jak i w intencji jego rodziny. Prośby dotyczyły również pochowania u boku współmałżonka, rodziców, rodzeństwa. Znacznie rzadziej dyspozycja zalecała jałmużnę lub obiady dla ubogich ${ }^{60}$.

Specjalne życzenia dotyczące ubioru, w którym chcieli być pochowani wyraziły dwie osoby. Kazimierz Ćwiklicz landwójt chcial, aby ciało jego

58 H. Żarek-Kleszcz (op. cit. s. 40) również zauważyła, że początkowo proste formuły polecające duszę Bogu z biegiem czasu znacznie rozbudowano. Wystąpiły one jednak w niewielu testamentach pabianickich. Autorka podaje 5 przykładów, zauważając, że najbardziej rozbudowana formuła pochodzi $z$ trzech testamentów, spisanych przez jednego pisarza. W testamentach sieradzkich $\mathrm{z}$ pocz. XVI w. formuły były z reguły proste. Bardziej rozbudowane stosowano tam sporadycznie podczas epidemii. W 9 przypadkach formuła nie wystąpiła (U. Sowina, op. cit., s. 10). Mieszczanie kieleccy powierzali duszę „Bogu, Pannie Maryi, aniołom stróżonı i wszystkim świętym" (J. Główka, op. cit., s. 326).

59 Najczęściej w tak ogólny sposób sformułowane zostały dyspozycje pogrzebowe mieszczan sieradzkich - 9 testamentów.

$60 \mathrm{~W}$ testamentach mieszczan sieradzkich tylko kilku testatorów wydało rozporządzenia dotyczące uroczystości pogrzebowych. Wyznaczano fundusze ze wskazaniem konkretnego przeznaczenia. Obejmowały one zapisy na wyprowadzenie ciała oraz towarzyszące temu egzekwie, śpiewanie psałterza, świece, które miały płonąc przy zmarłym, ucztę po pogrzebie oraz Msze Święte (U. Sowina, op. cit., s. 19). 
przebrano i pochowano po bernardyńsku. Musiał zresztą o tym pomyśleć dużo wcześniej bowiem wystarał się o zgodę prowincjała na taki pochówek (nr 32). Zygmunt Szulc prosił z kolei o strój franciszkański, chociaż jednocześnie chciał by bito w dzwony we wszystkich kościołach ( $\mathrm{nr} 48$ ).

W zasadzie rzadko wyznaczano sumę pieniędzy przeznaczoną na koszty pogrzebu (19 razy). Były to kwoty różnej wielkości, zależnie od stopnia zamożności i życzeń pogrzebowych: $150 \mathrm{zł}, 100 \mathrm{zł}, 50 \mathrm{zł}$ skończywszy na sumach 7 zł. Tylko w nielicznych przypadkach były to pieniądze odłożone i przekazane na koszty pogrzebu. Znacznie częściej sporządzający testament nakazywał spadkobiercom odebranie ich od dłużników, sprzedanie nieruchomości np. części żywego inwentarza, odzieży czy innych przedmiotów lub nieruchomości np. działek miejskich, gruntów, czy też ogólnie autorzy stwierdzali, że pieniądze mają być wypłacone $\mathrm{z}$ ich dóbr ${ }^{61}$. W dwóch przypadkach koszty pogrzebowe mieli pokryć beneficjenci legatów testamentowych (nr 15, 39).

W pozostałych przypadkach kosztami pogrzebu bez określania konkretnych sum czy przeznaczenia innych funduszów zostawali obarczeni najbliżsi, którym testator, będący na łożu śmierci zapisał swój majątek. Większość z nich to ludzie biedni, którzy zdając sobie sprawę ze stanu majątkowego swej rodziny realistycznie określali, aby pochowano ich „według przemożenia", t.j. według skromnych możliwości majątkowych.

Po omówieniu spraw związanych z ceremoniami pogrzebowymi przekazywano dodatkowe sumy na cele pobożne lub charytatywne. Ilość takich zapisów nie jest jednak imponująca. Uczyniło to jedynie 27 autorów testamentów. Nie znaczy to, że pozostali spadkodawcy „nie dbali” o zbawienie swojej duszy. Po prostu najczęściej, tylko nie wyznaczali w tym względzie konkretnych funduszy. Teresa Dorzbachowa Wołkowa prosiła męża, aby co rok „według przemnożenia swego za duszę moją do kościołów i ubogim dobrze czynił" (nr 51).

Józef Kalinowski, decydując się objąć funkcję dzwonnika, przekazał w kościołowi farnemu cały swój ruchomy majątek oraz zasiewy (nr 59). Trudno określić wielkość tego przekazu. Testator nie wymienił wszystkich rzeczy, dodając, że zostały spisane w osobnym dokumencie. Spadkobiercy jednak zostali obarczeni ewentualnymi kosztami pogrzebu.

61 H. Żerek-Kleszcz (op. cit. s. 41) również zauważa, że znacznie częściej sumy, które wyznaczano na pogrzeby pozyskane miały być ze sprzedaży części majątku lub odzyshar ne od dłużników. Mieszczanie kieleccy na pokrycie kosztów pogrzebu, nie wyznaczając konkretnych sum, kazali sprzedać: rolę, ogród, inwentarz (J. Główka, op. cit., s. 326). 
Zapisy wyjątkowo dużej wartości pochodzą od kilku osób. Najwięcej na cele religijne przeznaczył Kazimierz Ćwiklicz (nr 32). Był on złotnikiem. Zajmował się też pożyczkami pod zastaw i handlem zbożem. Pełnił wielokrotnie urzędy burmistrza i landwójta. Był osobą bardzo zamożną. Łączna wartość 31 legatów zawartych w jego testamencie upodabnia go bardziej do testamentów bogatej szlachty niż analizowanych w niniejszym artykule testamentów mieszczańskich ${ }^{62}$.

Wśród innych zapisów warto wspomnieć o przekazaniu przez Cecylię Lewoncewiczową 200 zł na wystawienie ołtarza błogosławionej Róży w kościele dominikanów, gdzie chciała być pochowana. Oprócz tego na msze do kościoła farnego $30 \mathrm{zl}$, kościoła bernardynów $30 \mathrm{zl}$, do cerkwi Przeczystej Bogurodzicy $10 \mathrm{zl}$ oraz 6 zł do szpitala Św. Ducha. Zapis ten trudno uznać za bezinteresowny, autorka wyraźnie bowiem stwierdziła, że uczyniła to by mógł „być ubłagany majestat boski za moje ciężkie grzechy” (nr 31)63. 'Teodor Karny kazał z trzech srebrnych łyżek zrobić puszkę i przekazać ją cerkwi katedralnej, dodatkowo przeznaczył 15 zł kościołowi różanostockiemu i 5 zł cerkwi jaczyńskiej (nr 40). Dość zaś dużą kwotę 375 długu mu należnego przekazał na kościoły, cerkwie i szpitale. Podobnie postąpił Mateusz Masłowski, który ofiarował 110 złotych polskich (nr 45). Przekazywano też bliżej nieokreślone sumy, które pozostaną po uregulowaniu długów lub odebraniu czynszów. Przekazy dotyczyły tez niewielkich sum np. Jadwiga Masnicka, tłumacząc się trudną sytuacją finansową, przekazała do Bractwa Trójcy Św. i Anioła Stróża tylko 5 zł oraz 5 zł dla „panien starych” do kościoła w Adamowiczach (nr 12).

Czterokrotnie przekazano grunt uprawny (nr 15, 22, 39, 53). W każdym z tych przypadków było to pół włóki. Jednak tylko Katarzyna Markiewiczowa ( $\mathrm{nr}$ 53) i Aleksander Karłowski ( $\mathrm{nr}$ 22) uczynili to w formie dobrowolnego zapisu, na cele pogrzebowe wyznaczając oddzielne sumy pieniężne. W dwóch pozostałych legat, jak wspomniano wcześniej, potraktowano i wliczono w koszta pogrzebu. Mikołaj Gudajewski legował Bractwu Trójcy Przenajświętszej plac syna (synowca), gdyby ten wcześniej zmarł (nr 19).

62 O. Hedemann, op. cit., s. 19-21.

63 Taki sposób uzasadnienia, jak trafnie zauważyła M. Borkowska (op. cit., s. 12) przypomina transakcję handlową. Z testamentów szlachty krakowskiej A. Falniowska-Gradowska podaje jeszcze bardziej wymowny przykład, w którym testator wprost mówi, że „W życiu nie uıniałem zarabiać sobie na niebo, przynajmniej chce go sobie kupić przed śmiercią" (Testamenty szlachty krakowskiej, s. XV). Pisał o tym już dużo wcześniej P. Dąbkowski (op. cit., s. 105), twierdząc, że pobożne legaty były rodzajem zamiany, wymiany dóbr doczesnych w zamian za zbawienie. 
Zapisy na cele religijne dotyczyły też konkretnych pojedynczych przedmiotów: ubrań, naczyń cynowych czy produktów żywnościowych np. zboża, soli.

Jeśli chodzi o strukturę legatów na rzecz kościoła, najczęściej obdarowywano świątynie, w których miały odbyć się uroczystości pogrzebowe. Przedstawione przykłady ilustrują również, że testator jednocześnie wyznaczał określone sumy na rzecz innych świątyń, nie koniecznie tego samego wyznania ${ }^{64}$.

Analizując legaty na cele pobożne należy zauważyć, że najczęściej były to długi lub sumy, które miały być wypłacone przez spadkobierców, w zamian za przekazany majątek. Spadkobiercy jednak nie spieszyli się z wykonaniem dyspozycji testamentowych. Nie uregulowawszy legatów za swego życia, zlecali w testamentach wykonanie ich swoim spadkobiercom. Przykładem może być testament Kazimierza Ćwiklicza, który przeznaczył 374 zł na uf undowanie ołtarza w kościele szpitalnym Św. Ducha, a była to część sumy, którą winna była tej świątyni jeszcze jego babka. Długi winne poszczególnym konwentom czy bractwom odnotowano również w innych testamentach. Nie zawsze określano ich wysokość i podawano w czyim imieniu były zaciągnięte.

Dyspozycje dotyczące majątku, wraz z wymienieniem długów, stanowią najobszerniejszą część testamentu. Analizę tej części przeprowadziłam zestawiając grono sparkobierców z zapisanymi im ruchomościami i nieruchomościami.

Analizując grono spadkobierców podzielono testatorów na 2 grupy. Pierwsza z nich to osoby, które nie pozostawił po sobie potomków. Łącznie wyróżniłam 20 takich dyspozycji. Wśród nich znalazło się: 13 bezdzietnych małżonków, 2 wdowy oraz 5 mężczyzn, których stanu cywilnego nie udało się ustalić.

Jeśli chodzi o małżeństwa, to w 7 przypadkach zapisów dokonano wyłącznie na rzecz współmałżonka, pozostawiając mu całkowitą dyspozycję, co do przekazanego majątku. Piotr Ciborowski zapisał wszystkie nieruchomości żonie, uzasadnia jąc to takimi słowami: „bom w dom jej do wszytkiego wstąpił” (nr 29). Lewon Zyskiewicz zapisał żonie pół włóki gruntu ojczystego

G4 Zwrócili już na to uwagę m.in. O. Hedeman, A. Karpiriski, S. M. Borkowska. S. Alexandrowicz, (Gospodarcze, prawne i etniczne osobliwości sieci miejskiej ziem Wielkiego Księstwa litewskiego $w$ XVI-XVII w., w: Miasto $i$ kultura ludowa $w$ dziejach Bialorusi, Litwy, Polski i Ukrainy, pod red. J. Wyrozumskiego, Kraków 1996, s. 67) zauważa, że był to wynik częstych mieszanych wyznaniowo małżeństw. 
i plac z domem, dwa zaś inne zadłużone place polecił sprzedać i przeznaczyć na koszty leczenia lub pogrzebu (nr 33). W pozostałych 6 oprócz współmałżonka odnotowano również innych spadkobierców. Hanna Tołłoczkowa Fiedorowa Jurewiczowa zapisała dwie trzecie domu 2 siostrzeńcom a jedną trzecią mężowi oraz folwark (nr 4). Wojciech Borysowicz zapisał połowę włóki cechowi rzeźnickiemu i połowę żonie, ale tylko dożywotnio, którą po śmierci miała przekazać temuż cechowi (nr 17). Andrzej Janucewicz zapisał domostwo wraz z wyposażeniem, kram oraz konia żonie. Bratu Michałowi $10(00 \mathrm{zl}$, drugi kram oraz kilka naczyń, w tym również cynowych. Drugiemu bratu Eliaszowi krowę oraz 38 zł długu mu winnego. W swoim testamencie uwzględnił on również niejakiego Kolendę, któremu legował parę sukien garniturowych, czapkę i pas (nr 72). W 3 innych testamentach zapisy wyraźnie wyróżniały współmałżonka, na rzecz dalszych krewnych przekazano nieznaczną część majątku, np. Jerzy Strzeczeń zapisał żonie: 3,5 włóki gruntu, wszystkie budynki oraz nieruchomości, polecając by ta wypłaciła z jego dóbr wychowankowi $30 \mathrm{zl}$, a bratankowi przekazała 4 beczki żyta (nr 16).

Wdowy, które znalazły się w tej grupie, z których jedna, jak sama przyznała nie doczekała się potomstwa ( $\mathrm{nr}$ 60), drugiej zaś dzieci zmarły ( $\mathrm{nr}$ 53) dokonały zapisów na rzecz dzieci siostry: siostrzenicy wspólnie z mężem i siostrzeńca.

Wspomniani wyżej mężczyźni przekazali majątek: Jan Fondeberk, pod warunkiem, że jego brat Stefan Jaworowski nie żyje, zapisał dobra nieruchome jak i ruchomości Kazimierzowi Ćwikliczowi. Ich pokrewieństwo nie zostało określone w testamencie, mógł być to jednak jego dalszy krewny, być może cioteczny brat. Rodziny bowiem Ćwikliczów i Fondeberków były ze sobą spokrewnione ( $\mathrm{nr}$ 8). Hans Hansbach oprócz rodziców, wymienil w testamencie dwóch współpracowników, określając ich mianem „chłopców". Zapisał im dwa talary, ponadto jednemu odzież, a drugiemu książki (nr 37). Ojca w testamencie uwzględnił również Teodor Karny, zapisując jednak większość bratu (nr 40). W 2 innych przypadkach zapisów dokonano na rzecz sióstr. Mateusz Masłowski zapisał obciążoną długami kamienicę z placem siostrze i szwagrowi. W testamencie zapis swój szczegółowo uzasadnił, zeznając, że nie opuścili go oni, gdy znalazł się trudnej sytuacji finansowej, i gdyby nie oni „przyszło było pod murem jako najuboższy żebrak duszę puścić" (nr 45). Józef Kalinowski, legował wszystkie ruchomości i zasiewy kościołowi, a siostrze sześcinę gruntu (nr 59).

W omawianej grupie testamentów przekazano majątek na rzecz: 3 siostrzeńców, 1 bratanka, 3 siostrzenic, 3 sióstr, 3 braci, 2 razy rodziców, wychowanka oraz trzech osób raczej niespokrewnionych. 
W drugiej grupie znalazły się testamenty osób, które pozostawiły potomstwo - testatorzy, którzy w chwili sporządzania testamentu pozostawali w stanie małżeńskim lub wdowim.

Zazwyczaj w pierwszej kolejności zabezpieczał testator współmałżonka. Zapisów na jego rzecz dokonywano w zasadzie na kilka sposobów. W przypadku współmałżonki wyznaczano dożywocie na określonych dobrach nieruchomych. Bezpośrednio jednak w swoich testamentach zaznaczyło to tylko 6 osób. Zygmunt Szulc, zapisal place synowi i córce, ale że, jak sam wspominal zostały one nabyte wspólnie $\mathrm{z}$ żoną, choć testament o tym wyraźnie nie mówi, najprawdopodobniej miała je dożywotnio użytkować żona, jeśli nie wszystkie, to najprawdopodobniej jakąś cześć. Zapisał jej również połowę nieruchomości (nr 48). Dożywotnio zapisała również swój posag mężowi w wysokości 2000 tynfów Marianna Badarkowa, miały one jednak pozostać w dyspozycji męża w przypadku przedwczesnej śmierci syna. Wartość przekazu powiększona zostałaby dodatkowo o zapis na jego rzecz w wysokości 2400 tynfów (nr 54). Łącznie więc zapisów dożywocia wyróżnić można 8.

Nie zawsze jednak możemy dokładnie sprecyzować rodzaj zapisu. Tylko 4 testatorów na 22 jasno i wyraźnie zaznaczyło, ze pozostawiło współmałżonkowi całkowitą dyspozycje w stosunku do przekazywanego majątku. Jan Adamowicz wyraźnie oświadczył, że żona ma prawo do całkowitej dyspozycji przekazanych ojczystych gruntów, komu będzie chciała może je darować lub przekazać. Uzasadnił swoją decyzję życzliwością i szacunkiem okazywanym mu przez małżonkę ( $\mathrm{nr} 21$ ). Również Cecylia Lewoncowiczowa potwierdziła urzędowy zapis na rzecz swego małżonka, któremu przekazała: dom z placem, „ponieważ wszelakiego doznawałam od niego poszanowania i utciwości, tak za dobrego zdrowia mego jako i w teraźniejszej chorobie mojej, zawdzięczając to jemu, stwierdzam zapis ... względem wniesionej jego sumy, którą zarabiając Bóg nam pobłogosławić raczył i żaden, tak z dzieci moich pierwsze[g]o małżeństwa, jako też z bliskich krewnych i powinnych moich nie ma turbować małżonka mego o ten dom i plac, ale małżonkowi memu wolno będzie tym domem i placem jako chcąc dysponować" (nr 31).

Najczęściej testatorzy, którzy dzielili majątek pomiędzy współmałżonka i pozostałe dzieci nie precyzowali dokładnie jego zasad. W przypadku małoletnich dzieci w ogóle nie dokonywano podziałów, wyznaczając tylko grono spadkobierców. Właściwego podziału miał więc dokonać pozostający współmałżonek - czy miał w tym całkowitą swobodę? Rzadko bowiem spotykamy jakieś szczegółowe dyspozycje co do przyszłych działów czy ograniczenia w tym względzie. Eliasz Iwaniszewski zastrzega, aby synowie wy- 
posażeni zostali z dóbr ojczystych, a córki macierzystych, ruchomości zaś miały zostać podzielone równo ( $\mathrm{nr} 47)$.

W jeszcze inny sposób zabezpieczył żonę Andrzej Stoliński. Zapisał on kamienicę córce i zięciowi, którzy mieli wypłacić jego małżonce 4 tys. $400 \mathrm{zł}$. Do czasu przekazania sumy spadkobiercy mieli zapewnić pozostałej małżonce wyżywienie i mieszkanie, a po uregulowaniu należności tylko mieszkanie, ale tylko do momentu ponownego zamążpójścia ( $\mathrm{nr} 82$ ). W testamentach mieszczan grodzieńskich wyjątkowo spotykamy się z podobnym rozwiązaniem. Co prawda również Karol Topolski zapisał 6 tys. zł. swojej drugiej małżonce $\mathrm{i}$ dzieciom $\mathrm{z}$ niej zrodzonym, ale otrzymała ona również dwór w Augustowie (nr 73).

W testamencie Katarzyny Starzyńskiej nie znalazł się zapis na rzecz męża. Przekazała ona tylko dzieciom nieruchomości, którymi do czasu osiągnięcia przez nie pełnoletności miał dysponować mąż. W przypadku jednak ich śmierci, miał je zatrzymać ( $\mathrm{nr}$ 68). Nie zapisał właściwie nic swojej żonie Jan Mickiewicz, przekazując majątek dzieciom, żonie zapewnił „do zgonu wolny chleb, odzienie i uszanowanie" ( $\mathrm{nr} 70$ ). Dwa inne zapisy również nie uwzględniały zapisów na rzecz współmałżonka. Jeden $\mathrm{z}$ nich to adytament (nr 80), w drugim zaś głównym powodem sporządzenia testamentu było zabezpieczenie córki z wcześniejszego małżeństwa ( $\mathrm{nr}$ 11). Tylko w jednym przypadku z powodu niemoralnego prowadzenia się żony nie uwzględnił jej mąż w swoim testamencie (nr 14).

Trudno określić jakąś jedną obowiązująca zasadę procentowego działu majątkowego pomiędzy współmałżonka i dzieci65. Jan Chackiewicz Wołk zapisał pół placu z budynkiem żonie, a drugą połowę dwójce dzieci - synowi i córce. Również zasiew żytni na uprawianej włóce podzielił na pół. Przekazując nieruchomości nieznacznie uprzywilejował dzieci, przekazując na ich rzecz narzędzia stolarskie i odzież (nr 9). Jan Adamowicz z pozoru wyraźnie uprzywilejował żonę, zapisał jej bowiem 1 1/2 włóki ojczystego

65 B. Groicki (Artykuly prawa magdeburskiego, s. 80) podaje, że kobiecie wdowie przysługiwała 1/4 części majątku; K. Bukowska (op. cit., s. 91-92) pisze, że najczęściej sąd przyznawał pozostałej żonie $1 / 3$ spadku po mężu. W XVII w. zwyciężyła zasada przyznawania połowy majątku. Uzależnione było to jednak od sposobu nabycia majątku. T. Zielińska (Rozważania nad kwestiq wyposażenia szlachcianck $w$ Wielkim Księstwie Litewskim wXVIII stuleciu, , Kwartalnik Historyczny”, R. 96, 1989, nr 1-2, s. 98); również J. Kulesza-Woroniecka (Rozwody $w$ rodzinach magnackich $w$ Polsce XVI-XVIII wieku, Poznaí - Wrocław 2002, s. 22 i n.) piszą, że wielkość przekazanego żonie spadku uzależniona była od wielkości wniesionego posagu. Uwagi te dotyczą magnaterii i szlachty, wydaje się jednak $w$ świetle prezentowanego materiału, że podobnie było również $w$ rodzinach mieszczaniskich. 
gruntu, pozostałym zaś dzieciom testamentownie przekazał po pół włoki gruntu. Posiadał on jednak liczne potomstwo i jeśli procentowo przeliczymy majątek przekazany na rzecz dzieci i żony, to każe się, że otrzymała ona 1/3 spadku po mężu. Najczęściej stosowaną i najbardziej powszechną zasadą był podział majątku, w którym uprzywilejowane były dzieci w stosunku do małżonka.

Wszystkie dyspozycje $\mathrm{z}$ wyjątkiem jednej. zawierały zapisy na rzecz dzieci. Mikołaj Gudajewski zapisał 2 włóki gruntu landwójtowi grodzieńskiemu Hanusowi Paulsenowi, w zamian za co ten miał wyprawić pogrzeb i pamiętać o Mszach Świętych. Tym samym wydziedziczył on swego syna, uzasadniając to $\mathrm{w}$ taki sposób: „w cic̨żkim upadku. i ubóstwie moim lat przeszłych od pomienionego synowca mojego wiele razy jako słowami uszczypliwemi i niewstydliwemi zelżony, a po kilkakroć i zbity ciężko". Dodaje on również, że wspomniane grunty, syn najprawdopodobniej zaraz by sprzedał za najniższą cenę, a o dusze rodziców niewiele by dbał (nr 9). Dwóch innych testatorów pominęło w dyspozycji jednego ze swoich potomków. Jadwiga Janucikowa zapisała grunt synowi i córce, drugiego zaś syna oddaliła od tych nieruchomości, zarzucając mu, że wziął za życia dwie pary wołów i zboże, głównie zaś dlatego, że opuścił ją i nie wspierał, gdy chorowała (nr 23). Inna testatorka oddalając od dziedziczenia jednego z synów podała podobne uzasadnienie ( $\mathrm{nr} 37)^{66}$.

Zasady podziału majątku pomiędzy potomstwo wydają się być również bardzo zróżnicowane. W przypadku pojedynczych małżeństw, sześciu testatorów w ogóle nie dokonało działów wyznaczając jedynie osoby spadkobierców. Kolejnych 9 podzieliło majątek pomiędzy współmałżonka i potomstwo, ale tylko $4 \mathrm{z}$ nich dokonało szczegółowych działów, pozostali przekazali spadkobiercom majątek do równego podziału. Osoby pozostające w stanie wdowim oraz testatorzy, którzy zawierali ponowne związki małżeńskie w zasadzie prawie zawsze dokonywali działów ruchomości i nieruchomości pomiędzy spadkobierców.

Bardzo trudno jest określić zasady tych działów. Chodzi przede wszystkim o określenie na ile często odstępowano od zasady równego działu. Nie były w nim brane pod uwagę dzieci wyposażone za życia testatora ${ }^{67}$. W ich

66 Powody, dla których rodzic miał prawo wydziedziczyć potomstwo szczegółowo podają: B. Groicki, Tytuly prawa magdeburskiego, s. 182-184; K. Bukowska, op. cit., s. 98. Podobne powody wymieniono w litewskim prawie ziemskim: Cmamym Вялікага Княства Лiтоускага 1588, Мінск 2002, s. 135-136.

67 K. Bukowska, op. cit., s. 90. 
przypadku spadkodawca zazwyczaj nie podawał wielkości uposażenia, a nawet liczby i płci dzieci. „Drugie dziatki już wyposażone” - pisał Fiedor Borsukiewicz (nr 14). Jeśli spadkobiercy „odprawieni za życia” chcieli być traktowani na równi $\mathrm{z}$ pozostałym potomstwem powinni byli położyć do równego działu wszystko to, co otrzymali wcześniej68. Taki sposób zastosowała Regina Przyłucka, wymieniając ruchomości i nieruchomości zleciła, aby wszystko zostało urzędowo oszacowane i równo podzielone pomiędzy dwóch synów i dwie córki. Nakazała również, aby uwzględniono klejnoty, które córki wzięły już w posagu, również perły, które córka miał na szyi. Zastrzegła jednak, aby synowie przejęli nieruchomości - grunty i dom (nr 2).

Najczęściej grodzieńscy testatorzy, zgodnie z przyczyną jaką podawali w momencie sporządzania testamentu, dokonywali równych działów majątkowych, tak aby żaden z potomków nie został pokrzywdzony. Cecylia Lewoncowiczowa przekazała włókę gruntu po pierwszym mężu do równego działu trzem synom (nr 31). Inna z testatatorek zapisała plac "pod górą" na pół dwóm swoim córkom wspólnie $\mathrm{z}$ zięciami i drugi plac $\mathrm{w}$ Rylowcach również na pół (nr 34).

Maciej Kasjanowicz potwierdził zapis sześciny gruntu na rzecz syna \% pierwszego małżeństwa, pozostałe dzieci były już zapewne wyposażone, nadmienił on o nich niejako przypadkowo, zastrzegając, że nie mają prawa rościć sobie pretensji do przekazanego synowi gruntu. Były to zapewne córki, którym w przypadku posiadania męskiego potomstwa rzadko zapisywano grunty rodzinne. Drugiej zaś małżonce i dwóm synom zapisał pół włoki wraz z zabudowaniami i nieruchomościami. W pierwszej chwili podział wydaje się być wielce krzywdzący dla syna z pierwszego małżeństwa. Jeśli weźmiemy jednak pod uwagę, że spadkobierców było 4, włącznie z żoną, która przecież musiała z czegoś żyć, to każdy z nich otrzymałby tylko szęścinę gruntów. Nie wiemy też jakie nieruchomości otrzymał pierwszy syn wcześniej? Podział więc ten, $\mathrm{z}$ pozoru nierówny, nie musiał wcale być krzywdzący. Przykład ten wskazuje jak trudną i skomplikowaną sprawą jest rozstrzygnięcie na ile często dochodziło do nierównych działów majątkowych.

I tak na 61 testatorów, którzy pozostawili potomstwo tylko 11 dokonało nierównych działów majątkowych. Pięć dyspozycji sporządzono wyraźnie na korzyść synów względem córek. Jan Mickiewicz zapisał cały majątek synowi tj.: „,cały sprzęt i całe gospodarstwo mojej ubogiej substancji, jako żywioły jak i zabudowanie, gruntu zaś pół włóki ze wszystkimi przynależnościami, ogrodami, sadami owocowymi i nieowocowymi, [k. 83] gajami, lasami,

68 Ibidem. 
wypustami, sianożęciami i cokolwiek do tego gruntu należeć ma". Pod jego opieką miała zostać córka, która miała otrzymać, wychodząc za mąż, czwartą część nieruchomości i grunt według taksy (nr 70). Roman Makar wyraźnie uprzywilejował syna, zapisując mu włókę gruntu, a dwóm pozostałym córkom po ćwierci. Zabudowania i nieruchomości również wyróżniały syna (nr 49). Korzystniejszego zapisu na rzecz dwóch synów w stosunku do dwóch córek dokonał Piotr Lewkowicz (nr 13). W dwóch innych przypadkach córki nie otrzymały nieruchomości, ale jedynie gotówkę i nieruchomości (nr 79, 35). W jednym testamencie uprzywilejowano córkę w stosunku do syna. Anna Mleczkowa zapisała synowi włókę gruntu, a córce półtorej oraz dom z placem i nieruchomościami (nr 15). W jednym również testamencie uprzywilejowano najmłodszą córkę w stosunku do pozostałych, „przy której przez cały rok w chorobie zostawałem, i w chorobie mojej mnie doglądywała" - uzasadnił testator ( $\mathrm{nr}$ 43). Fiedor Borsukiweicz zapisał czterem synom po pół włóki, dwóm córkom zaś na pół ćwierci, na koniec jednak uzupełnił zapis na korzyść najmłodszego syna, legując mu jeszcze pół włóki, które miały wcześniej przypaść jego żonie, uzasadnił dyspozycje tym, że wspomniany syn „mojej starości dotychczas pilnował i mnie w starości mojej doglądał" (nr 14). Również Jan Adamowicz, który wydawałoby się, że starał się nie wyróżniać żadnego z dzieci uprzywilejował jednego z synów. Trzem niezamężnym córkom legował po pół włóki gruntu. Dwie inne były już mężatkami, jednej potwierdził również zapis na pół włoki, a w stosunku do Katarzyny, stwierdził, że „tej się we wszystkim dosyć stało, nie ma o żadną rzecz bracią i sióstr turbować". Można więc założyć, że dostała uposażenie takie samo jak pozostałe córki ${ }^{69}$. Dwóm niewyposażonym synom również przekazał po pół włoki gruntu, jednak najstarszemu wydzielonemu wcześniej potwierdził zapis na 1 1/2 włóki (nr 21). Jeden z synów wyraźnie został uprzywilejowany, nie wiemy jednak dlaczego. Nie wynika też $\mathrm{z}$ testamentu czy były to dzieci $\mathrm{z}$ jednego małżeństwa. $\mathrm{W}$ przypadku bowiem kilkukrotnych związków starano się przestrzegać zasady podziału majątku, wniesionego, nabytego i pomnożonego podczas wspólnego małżeństwa na rzecz dzieci z tego właśnie związku. Karol Topolski majątek „nabyty i zapracowany” z pierwszą żoną przekazał na rzecz potomstwa zrodzonego z tego związku, drugiej zaś żonie i 4 synom zapisał znacznie

69 J. Bardach, B. Leśniodorski, M. Pietrak (Historia państwa i prawa polskiego, s. 236) podaje, że według prawa wszystkim córkom należał się posag w równej wysokości. T. Zielińska (Rozważania..., s. 98) i I. Kulesza-Woroniecka (op. cit., s. 22) piszą, że nie zawsze przestrzegano tej zasady, i czessto zależne było to od pozycji społecznej pana młodego. 
mniej (nr 73) ${ }^{70}$. W przypadku bowiem uposażonych dzieci z wcześniejszego małżeństwa można opisać przypadek testamentu Anny Mikiciny, który policzyłam jako przykład pokrzywdzenia jednego $\mathrm{z}$ potomków. Zeznała ona, że dwoje dzieci: syn i córka, są już wyposażeni. Zapisała niewyposażonej córce ćwierć gruntu, drugą zaś ćwierć na pół drugiej niewyposażonej córce i wyposażonemu synowi. $\mathrm{W}$ tym wypadku pokrzywdzona niejako została córka z pierwszego małżeństwa (nr 27).

Oprócz potomstwa w 8 testamentach uwzględniono wnuki, w jednym zaś zapisu dokonano na rzecz wnuczki siostry (nr 69). Dorota Łagowska legowała pół placu i 1,5 włóki gruntu synowi, a wnuczce pół placu i pół włoki gruntu (nr 6). Ohapia Jędrzejczykowa zapisała plac córce, a drugi na pół jej córkom, a swoim wnuczkom w posagu (nr 38). Maryna Juchniewiczowa zapisała po pół ćwierci gruntu córce, wnukowi i wnuczce - dzieciom innej już nieżyjącej córki, ale chatę, zabudowania gospodarcze, zasiew jarzyny na wszystkich gruntach, jak również wszelką nieruchomość legowała wnukom (nr 67). W czterech pozostałych przypadkach zapisy dotyczyły nieruchomości: wnuczce siostry jeden $\mathrm{z}$ testatorów legował kocioł miedziany do robienia piwa oraz lustro $\mathrm{z}$ lichtarzem ( $\mathrm{nr}$ 69), w pozostałych przypadkach była to odzież (nr 22, 43, 71) oraz pieniądze - 40 czerwonych zł (nr 2). Wśród innych krewnych wymienić można legaty na rzecz: 6 sióstr, 3 braci, 2 matek, 2 zięciów, 1 synowej, 2 bratanków, pasierba, szwagra z żoną oraz dalszej krewnej określonej mianem powinowatej. Zapisy na ich rzecz dotyczyły części gruntów (nr 22, 24, 26, 47, 61, 67, 26), odzieży i inwentarza oraz kwot pieniężnych (nr 2, 5, 9, 31, 51, 69, 71). W jednym tylko przypadku testator zapisał w zasadzie całość majątku siostrze, która jak stwierdził „powinna będzie wszystkie dzieci moje uspakajać" (nr 69). W 4 testamentach przekazano legaty na rzecz osób niespokrewnionych. Regina Przyłucka zapisał swemu parobkowi $30 \mathrm{zl}$ (nr 2). Swego ucznia uwzględnił również inny $\mathrm{z}$ testatorów (nr 69). O rozporządzeniu Mikołaja Gudajewskiego wspomniano dokładnie powyżej, zaś Ludwik Benedykt Laffaye zapisał Pani Joannie Szteynowej 100 zł gotowych pieniędzy, ponieważ opiekowała się nim w chorobie (nr 77).

Oddzielnie wypada omówić testament Kazimierza Ćwiklicza, oprócz bowiem małżonki i córki, wymienił on w swoim testamencie wielu innych członków rodziny, którym zapisał pojedyncze przedmioty. Trzem szwagierkom po diamentowym pierścionku, siostrze i dwóm stryjom przekazał ubrania. Jednemu ze stryjów również $10 \mathrm{z}$. Siostrze zaś dodatkowo umorzył dług

70 Zob. A. Pisanko-Borowik, Karol Topolski..., s. 173-178. 
w wysokości 800 «ł. również inny dług w wysokości 140 zł. Przedınioty będące w zastawie kazał zwrócić, traktując: zapis jako legat na rzecz dzieci stryjecznej siostry. Ponadto przekazal: siostrzenicy 3 sznury perel, innej krewnej 2 małe sznurki pereł. W testamencie nakazał również przekazanie pary blachmatowych noży i szabli ojcu, a matce łyżki blachmatowej. Są to jednak najprawdopodobniej rodzice jego żony, ponieważ jego, jak sam na początku testamentu wspomniał nie żyli. Również trzem synom niejakiej Trojanowskiej przekazał 6 talarów, trudno jednak określić z jakiego rodzaju pokrewieństwem mainy tu do czynienia? Pasierbowi swemu. któremu według podziału przypadło pół placu i domu, podarowal drugą część. Czeladnikowi polecił oddać 2 sztuki odzieży oraz legował mu $15 \mathrm{zl}$ (nr 32).

\section{Ruchomości i nieruchomości przekazywane na mocy testamentu}

Wśród nieruchomości najczęściej przekazywano grunty uprawne, zazwyczaj określając ilość włók i ich lokalizację, zaznaczano też czy są zasiane czy nie. Wyróżniano grunty dziedziczne: ojczyste i macierzyste, zakupione jak również otrzymane na mocy przywilejów królewskich. Grunty uprawne przekazało spadkobiercom 56 testatorów. W czterech przypadkach na podstawie testamentu, nie jesteśmy w stanie określić wielkości przekazanej nieruchomości. Autorzy bowiem ogólnie zeznali, że przekazują spadkobiercom grunty (nr 2, 28, 29, 57). W przypadku Zofii Ćwikliczowej skądinąd wiemy, że dysponowała ona 8 włókami i 20 morgami gruntu (nr 28) ${ }^{71}$. W trzech innych testamentach określono przekazywany grunt jako folwarki - również nie określając: ich powierzchni. Tylko w testamencie Maryny Fandenbergowej na marginesie znajduje się późniejszy dopisek, że folwark św. Mikołaja składał się z trzech włók gruntu ( $\mathrm{nr} 3$ ). W dwóch pozostałych wielkość nie została określona ( $\mathrm{nr} 4,35)$. Ilość włók, którą testatorzy przekazywali spadkobiercom była zróżnicowana. Najwięcej swoim spadkobiercom przekazali wspomıniana już wyżej Zofia Ćwikliczowa (nr 28) i Jan Adamowicz - 6 włók (nr 21), Paweł Worobiej - 4 włóki (nr 10), dwóch innych testatorów grunty o powierzchni 3,5 włóki (nr 16) i 3 włóki (nr 2). Najmniej bo zaledwie 1/6 włóki Józef Kalinowski (nr 59), 1/8 włóki przekazał Mi-

71 Wcześniej w 1667 r. synowi Kazimierzowi scedowała zaścianek w Suchym Siole " sadzibą (8 włók 20 mórg), który wraz z mężem Foltynem posiadała na mocy konsensu jure colonorum Zygmunta III wydanego w Warszawie 2.IX.1631 r. po mieszczance Kudar jewskiej, NAHB w Mińsku, F. 1800, op. 1, nr 1, k. 152v; F. 1882, op. 1, nr 1, k. 21. 
chał Łukaszewicz (nr 81), 3/8 włóki - Teresa Wołkowa (nr 51). Autorzy testamentów, wymieniając grunty jako część spadku, nie zawsze byli ich realnyıni posiadaczami. Niekiedy użytkowali dożywotnio grunty należące do ekonomii grodzieńskiej. Często zaciągali również długi pod zastaw gruntów uprawnych, które spadkobiercy zobowiązani byli spłacić. Zaznaczano więc wyraźnie w testamencie czy grunty są „wolne" czy też obciążone zastawem. Mikołaj Gudajewski przekazał swoim spadkobiercom dwie włóki gruntu, z których pół włóki była zastawiona w kwocie 30 zł (nr 19). Nakazywano również spadkobiercom sprzedanie części gruntu na pokrycie długów (nr 22). Zdarzało się, że wszystkie przekazywane testamentem włóki były zastawione. 'Irudno jest natomiast w konkretnych przypadkach stwierdzić, czy wymienianie ich w testamencie i przekazywanie praw do ich wykupu spadkobiercom spowodowane było faktem, że suma zastawu mniejsza była od ich wartości rynkowej czy też może przywiązaniem do gruntów ojczystych. Paweł Worobiej wymienił w testamencie 2 włóki ojczyste, $\mathrm{z}$ których swoją część ( 0,5 włóki) sprzedał już wcześniej, część siostry (0,5 włóki) oraz części dwóch swoich braci, które zastawił za $60 \mathrm{zł}$. Dysponował on również 3 włókami gruntu, które otrzymał na mocy przywileju króla Władysława IV. Dwie z nich zastawił w 200 zł landwójtowi grodzieńskiemu, również trzecia, podzielona na pół znajdowała się w zastawach, w łącznej kwocie $55 \mathrm{zł}$.

W zestawieniu poniższym uwzględniłam wszystkie grunty uprawne, które prawem własności czy też dożywotniego użytkowania przekazano spadkobiercom, o ile możliwe było ustalenie ich wielkości.

Tabela 1. Powierzchnia gruntów uprawnych przekazywanych w testamentach mieszczan grodzieńskich w XVII-XVIII

\begin{tabular}{|l|c|c|c|}
\hline \multirow{2}{*}{ Ilość włók } & \multicolumn{3}{|c|}{ Ilość testamentów z: } \\
\cline { 2 - 4 } & XVII w. & XVIII w. & Razem \\
\hline do 0,5 & 0 & 3 & 3 \\
0,5 & 7 & 6 & 13 \\
pow. 0,5 do 1 & 4 & 7 & 11 \\
1 & 3 & 2 & 5 \\
pow. 1 do 2 & 2 & 2 & 4 \\
2 & 3 & 3 & 6 \\
pow. 2 do 3 & 3 & 0 & 3 \\
3 i pow. & 5 & 1 & 6 \\
\hline \multicolumn{1}{|c|}{ Razem } & 27 & 24 & 51 \\
\hline \multicolumn{2}{|c|}{}
\end{tabular}


Zestawienie powyższe wskazuje, że malał znacząco areał, którym dysponowali mieszkańcy Grodna. Jeszcze w XVI w. przeciętne gospodarstwo rolne wynosiło 1,9 włóki ${ }^{72}$. Według moich obliczeíı w 25 testamentach z XVII wieku przekazano spadkobiercom 39 1/6 włóki. Przeciętne więc gospodarstwo miało wtedy wielkość 1,56 włóki ${ }^{73}$. W XVIII stuleciu przeciętny testator dysponował już tylko gospodarstwem o wielkości 0,95 włóki (w 24 testamentach przekazano łącznie tylko 22 17/24 włóki). W XVIII w. wśród właścicieli posiadających powyżej dwóch włók wymienić możemy jedynie Bartłomieja Ćwiklicza, który dysponował 3 włókami (nr 44). W XVII wieku takich testatorów było więcej. Wcale też wówczas nie wystąpiły gospodarstwa mniejsze niż pół włókowe. Dla ustalenia wielkości przeciętnego gospodarstwa rolnego testamenty mieszczan grodzieńskich, okazały się źródłem nie tylko pomocnym, ale wobec braku innych źródeł w zasadzie jedynym, który takie szacunki umożliwił ${ }^{74}$.

Gruntów uprawnych nie wymieniono w 25 testamentach. W trzech z nich nie możemy wykluczyć, że w skład przekazywanych dóbr nie wliczono gruntów. Zapisy bowiem są sformułowane ogólnie, bez rozróżnienia majątku ruchomego i nieruchomego ( $\mathrm{nr} 7,8,75)$. Tylko w 22 dyspozycjach ostatniej woli nie przekazano gruntów. Wśród nich jeden to uzupełnienie wcześniejszego testamentu ( $\mathrm{nr}$ 80), a drugi - Anny Jordanowej Tobiaszowej Dorzbachowej jest w zasadzie potwierdzeniem wcześniejszej woli testamentowej męża, do której wprowadziła nieznaczne zmiany. Testatorzy, którzy nie przekazali gruntów w większości to osoby, posiadające konkretny zawód.

Grunty uprawne, jak wynika z testamentów były najważniejszym składnikiem przekazywanego majątku. Nie musi to jednak świadczyć, iż mieszkańcy Grodna zajmowali się głównie rolnictwem. Jeśli weźmiemy pod uwagę, że na 56 testatorów, tylko 22 mieszkało w Grodnie, a $11 \mathrm{z}$ nich to osoby należące do patrycjatu, to okaże się, że przeciętny mieszkaniec Grodna, rzadko posiadał ziemię ${ }^{75}$.

72 P. Borowik, Jurydyki miasta Grodna..., s. 287.

73 Nie biorę tu pod uwagę dwóch testamentów, w których wymieniono grunty podległe jurysdykcji zamkowej i proboszcza nr 3, 28.

74 H. Łowmiański, Studia nad dziejami Wielkiego Księstwa Litewskiego, Poznań 1983, s. 473. W Mohylewie w 1604 r. 235 włók w tym mieście było w posiadaniu 212 osób, a więc przeciętne gospodarstwo wynosiło 1,10 włóki. Włókę gruntu przekazano w testamencie tylko raz.

75 J. Bardach, O dawnej i niedawnej Litwie, Poznań 1998, s. 111-112. Potwierdza on w tym względzie zasadność kwestionowania przez H. Lowmiańskiego i J. Ochmańskiego te- 
W skład nieruchomości w następnej kolejności wchodziły place oraz zabudowania tj. domy i budynki gospodarcze. Podawano ilość placów, ich lokalizację zaznaczano również place puste i zabudowane. W XVII wieku 23 testatorów wymieniło place. Trzech $\mathrm{z}$ nich posiadało tylko połowę placu, 13 po jednym, 1 osoba 2 , dwie po 2,5 placa, 3 po 3 place, jedna zaś z testatorek ogólnie zapisała „dom [...] z placami”. W XVIII wieku place jako składnik przekazywanych nieruchomości staja się rzadkością. Wymienia je bowiem tylko 7 testatorów. Jeden $\mathrm{z}$ nich dysponuje 3 placami ( $\mathrm{nr}$ 53) zaś Zygmunt Szulc ogólnie stwierdza, że zapisuje potomkom place zabudowane i niezabudowane ( $\mathrm{nr} 48$ ). Podobnie jak w przypadku gruntów zaznaczano place dziedziczne i zakupione. Nieruchomości te również były przedmiotem zastawu. Lewon Zyskiewicz zapisał spadkobiercom dom z placem, na którym ciążył dług w wysokości 28 złoty, dwa zaś inne place, jak zeznał testator „przy ciężkim ubóstwie moim w chorobie mojej są zawiedzione, które zlecam małżonce mojej, aby póki jeszcze żyję na poratowanie zdrowia mego, albo też jeśli umrę na pogrzeb, przedała" (nr 33). Krystyna Paciukowana Piotrowa Marcinowiczowa wymienia dwa place, $\mathrm{z}$ których jeden w Rylowcach obciążony był długiem - 10 zł (nr 34). Również Marcin Makowski, zapisał małżonce i dzieciom: dom $\mathrm{z}$ placem, drugi plac na Horodnicy określił jako „wolny”, trzeci zaś zastawiony był za 200 zł, który dzieci lub małżonka mogły wykupić (nr 41). Katarzyna Ćwikliczówna wydała dokładne dyspozycje dotyczące jej nieruchomości. Zapisała siostrzeńcowi pół placu z zabudowaniami, na którego oddłużenie przekazała inny plac. Trzeci „Szmarowszczyzna nazwany" zapisała dłużnikom, którym winna była 70 talarów (nr 53).

Budynki mieszkalne i gospodarcze wymieniono w 51 testamentach. W 10 dyspozycjach odnotowano ogólnie przekazanie na rzecz spadkobierców: wszystkich budynków, zabudowań, domostwa, bez wyszczególnienia. W 17 przypadkach dokładnie wyliczono: budynki mieszkalne, przy czym dwukrotnie pojawia się nazwa chata, trzy razy natomiast jest to jedynie izba, z sieńmi i komorą. Wśród budynków gospodarczych wymieniano: obory, gumna, chlewy, odryny, szopy, spichlerze. Określenie dom pojawia się tylko w 18 dokumentach. Chodzi zapewne o drewniane budynki, które często przekazywano łącznie $\mathrm{z}$ placem. $\mathrm{Z}$ zasadzie w testamentach, wyłączając usytuowanie, brak opisów domów lub są one bardzo ogólne. „Dom mój w Rynku na rogu stojący ze wszystkim, jako sam w sobie stoi, tak w drewnie jako

zy o przeważająco agrarnym charakterze miast Wielkiego Księstwa Litewskiego. Również ostatnio P. Borowik (Jurydyki miasta Grodna, s. 287) dowodzi, że przeciętny mieszkaniec Grodna rzadko posiadał ziemię. 
w murze i z tylnym budowaniem" - czytamy w testamencie Maryny Hanusowej Fanddenbergowej ( $\mathrm{nr}$ 3). Nieliczni z mieszczan grodzieńskich posiadali dwa budynki mieszkalne. Piotr Lewkowicz wymienia dom $\mathrm{z}$ ogrodem na ul. Rzeźnickiej i nowopobudowany drugi dom (nr 13). Godfryd Born, który dokładnie opisuje swoje nieruchomości, był właścicielem dwóch budynków mieszkalnych z alkierzykami i komórkami, 5 spichlerzów, stajni, szopy i budynku ogrodowego ( $\mathrm{nr}$ 69). Pięć osób posiadało kamienice, których wartość, ze względu na budulec znacznie przewyższała cenę budynków drewnianych (nr 32, 45, 73, 74, 82). Jeden $\mathrm{z}$ nich - Karol Topolski był właścicielem kamienicy w Grodnie, drugiej z dworkiem na Nowolipiu w Białymstoku, jak również dworu w Augustowie (nr 73). Również w przypadku kamienic brak dokładniejszych danych na temat obiektów. Ich wielkość i rozmiary mogły być różne od bardzo skromnych po okazałe budowle ${ }^{76}$. Kamienica 'Topolskiego w Białymstoku to wielki, dwupiętrowy budynek, obok którego stały stajnia, spichlerz, szopa i wozownia ${ }^{77}$. Również stan zachowania nie był bez wpływu na wartość obiektu ${ }^{78}$. Wartość kamienicy, którą w 1671 roku w testamencie przekazał spadkobiercom Kazimierz Ćwiklicz, musiała być znaczna. W 1794 r. wyceniono ją na 12 tys. złotych, przy czym budynek ten wcześniej został zniszczony podczas pożaru w $1753 \mathrm{r}$. i w zasadzie nigdy go nie odremontowano ${ }^{79}$. Kamienica Topolskiego w Grodnie stanowiła zabezpieczenie 6 tys. zł, które dzieci z pierwszego małżeństwa miały wypłacić jego drugiej żonie. Wartość zaś całkowitą w 1794 r. oszacowano na 10 tys. zł ${ }^{80}$.

W dwóch testamentach przekazano prawo własności do kramów miejskich. Andrzej Janucewicz posiadal ich dwa (nr 72), inna testatorka jeden murowany w Rynku ( $\mathrm{nr}$ 64). W jednym dokumencie wymieniono karczmę (nr 80).

Warto zwrócić uwagę na nieruchomość zwana „piekarnią” lub „piekarenką", która wzmiankowana jest w testamentach aż 7 razy $(\mathrm{nr} 14,19,26$,

76 T. Zielií ıska, Szlacheccy wlaściciele nieruchomości w miastach $w$ XVIII $w$.; por. Typy i funkcje nieruchomości szlacheckich, Warszawa - Lodź 1987, s. 47.

77 Teki Glinki, teka 107, s. 10-11. Szczegółowy opis kamienicy oraz zabudowań gospodarczych przedstawiła: A. Sztachelska-Kokoczka, Kwadrat Rynku jako centrum handlowe Bialegostoku w XVIII wieku, „Białostoczyzna” 1990, nr 3, s. 2.

78 Ibidem. Podaje, że wartość kamienicy z powodu złego stanu zachowania oszacowano na 6 tys. zł, a po remoncie jej wartość wynosiła już 20 tys. zł.

79 Wiadomość o pożarze zdarzonym 175.3 roku w Grodnie, w: Ondyna Druskiennickich Źródel, Grodno 1846, s. 36; Spis mieszkańców Grodna z 1794 r., opr. J. Urwanowicz, w: Grodno w XVIII wieku. Miasto i ludność (na tle trendów rozwojowych od średniowiecza do 1939 roku), pod red. A. Woltanowskiego i J. Urwanowicza, Białystok 1997, s. 69.

80 Spis mieszkańców Grodna z 1794 r., s. 69. 
44, 53, 64, 78) Często usytułowana ona była w ogrodzie, choć nie zawsze. W testamencie Fiedora Borsukiewicza wspomina o nim jego żona, twierdząc, że spłonęła ona podczas najazdu moskiewskiego (nr 14). W innyın testamencie nie wzmiankowano tej nieruchomości, z innych źródeł wiemy, że w wyniku zawartego w 1670 r. kompromisu między spadkobiercami Fedora Bobrykiewicza jego córce Połosi przypadła trzecia część placu na ul. Podolskiej oraz czwarta część budynków i ruchomości. Wraz z matką przypadł jej również świren, gumno, piekarnia, browar i pół kotła piwnego oraz inne ruchomości (nr 37).

Wśród innych nieruchomości wyróżnić można ogrody. Wspomniano o nich tylko w 8 przypadkach. Nazwa użyta w testamentach określa jednak różnego rodzaju nieruchomości. Cztery razy mowa o ogrodzie, który znajdował się przy domu i stanowił niejako część placu miejskiego (nr 13, 26, $44,77)$. Godfryd Born dokładnie opisu je: „ogród z drzewami owocowymi, na którym budynek jeden ogrodowy i piekarnia jedna" oraz sadzawka (nr 69). Nieruchomości nazywane ogrodami w testamencie Kazimierza Ćwiklicza, jedna na ul. Kaluczyńskiej, druga na Przedmieściu Zaniemeńskim określić można raczej działkami, użytkowanymi jako ogród (nr 32). Jeden również z wcześniej wspomnianych testatorów przekazuje prawo własności na ogród w Suchym Siole (Horodnica) zastawiony za 160 zł (44). W dwóch innych testamentach ogród nie był własnością testatora. Maryna Fandenbergowa użytkowała ogród zasiany żytem, który trzymała w zastawie 150 zł (nr 3). Jan Adamowicz wymienił zaś ogród jako własność swego siostrzeńca, nad którym sprawował opiekę (nr 21).

Ruchomości to kolejna część dyspozycji majątkowych. Skupiłam się w tym względzie na omówieniu najistotniejszych, szczegółowe bowiem, moim zdaniem, ich opisywanie znudziłoby czytelnika.

W 21 testamentach nie uwzględniono ich w ogóle. Zapisy ograniczały się jedynie do nieruchomości. W niektórych testamentach spadkodawcy zaznaczali: „przy ubóstwie moim w szpitalu zostaję i żadnej ruchomości nie mam" - Anna Siemienowa Mikycina (nr 27). Jadwiga Janucikowa rozpoczyna swój testament, niejako tłumacząc się: „nie mając żadnej ruchomości, bo to wszystko przez incursją moskiewską utraciła i leżąc przez lat kilka choroba ciężka obłożona ze wszystkim [po]stradać musiała" (nr 23). Podobnie Dorota Lagowska, „iż ...postradawszy wszytkich dóbr i fortun swoich, przez pierwszą i drugą inkursią nieprzy jacielską do Grodna, a co większa i miłego małżonka swego, w testamencie przekazała jedynie pozostałe jej nieruchomości" (nr 6). W testamentach z XVII wieku również 8 innych testatorów wspominało, że to właśnie $\mathrm{w}$ wyniku wojny polsko-moskiewskiej utracili 
znaczną część swego majątku. W testamencie Krystyny Filipowiczowej odnotowano jedynie, że przekazała ona "dobra" swemu mężowi (nr 7).

W kolejnych 8 adnotacje są bardzo ogólne i ograniczają się do stwierdzenia przekazania całego majątku ruchomego na rzecz spadkobierców.

W5 1 testamentach wymienia się poszczególne składniki majątku ruchomego. W niektórych przypadkach oprócz ogólnego stwierdzenia przekazania ruchomości nadmieniono jedynie, że w skład przekazu wchodzi np. inwentarz, ule, Anna Dorzbachowa, zapisała synowi dom ,... z browarem i kotłem piwnym, do tego statkami browarowemi i ze wszystkim sprzętem domowym" (nr 26). Warto przy tej okazji wspomnieć, że przyrządy do warzenia piwa wymieniło również innych 7 testatorów. Piotr Ciborowski swoją dyspozycją sformułował: „Tejże małżonce mojej dobra wszytkie moje, od mała do wiela, konie, byd ło rogate i nierogate i cokolwiek jest $\mathrm{z}$ ruchomości: cynę, miedź małżonce mojej leguję" (nr 29). Szczegółowe dyspozycje ruchomości nie były konieczne, gdy spadek przejmowała żona z małoletnimi dziećmi, pojedynczy spadkobiercy: żona i dzieci.

Z dokładnym i szczegółowym wyliczeniem poszczególnych składników ruchomości mamy do czynienia zazwyczaj, gdy grono spadkobierców obejmowało małżonka, dorosłe dzieci, często z kilku związków oraz dalszą rodzinę. Równiez testatorzy pozostający w stanie wdowim dokładnie wyliczali składniki ruchomości. Często wówczas drobiazgowo wyliczano $\infty$ komu, i w jakiej ilości się należy.

Wśród najczęściej zapisywanych spadkobiercom nieruchomości wymienić należy zwierzęta (33 testatorów). Wymieniano również szczegółowo: woły, krowy, cielęta, konie, świnie, prosięta, owce, kozy, ptactwo, pszczoły, określano wiek, maść i liczbę. Wielkość przekazywanego inwentarza była znacznie zróżnicowana. Wymienić możemy dwa skrajne przypadki: Maryny Fandenbergowej, która zapisała 6 par wołów, 10 krów, 4 cielaki, 20 owiec, 3 kozy i 3 kozły, 5 świń, oraz gęsi (nr 3) i Krystyny Marcinowiczowej; która przekazała mężowi jednego wołu, i świnie z 2 prosiętami (nr 34). Trudno podać w tym przypadku jakieś ogólne średnie, zważywszy, że często testatorzy inwentarz określali mianem bydła rogatego i nierogatego. Wspomnieć natomiast można, że dość często wrmiankowano konie. Wymieniło je 13 testa-: torów. Zazwyczaj byli właścicielami jednego, w 2 czy 3 przypadkach dwóch. Dziewięć razy wzmiankowano również pszczoły.

' Istotną pozycję w testamentach zajmuje odzież. Wymieniło ją w 23 testatorów. Często poszczególne części ubiorów rozdzielano pomiędzy szerszes grono spadkobierców. Często, obok inwentarza były to jedyne ruchomości, którymi zmarły mógł obdarować bliższych czy dalszych krewnych. Piotr 
Lewkowicz zapisuje córce „w niedostatku" żupan swój fiołkowy oraz nasuwień, a matce drugi siwy, podszyty czerwoną bają (nr 13). Hanna Jurewiczowa zapisała siostrzenicom jednej - letnik turecki wiśniowy, a drugiej półczamarek i suknię ( $\mathrm{nr}$ 4). Maryna z Makarewiczów Taurelowa zapisała „odzież wszelką po onym Franciszku Taurelu, która że jeszcze dopiero się znajduje z sukien, fant, płocien wszystko synowi memu Józefowi należeć powinna. Spódnicę moją szarżewą wnuczce mojej Urszuli córce Macieja daruję, a kamizel synowej mojej Józefowej” (nr 71). W większości testamentów przekazywane ubiory ograniczały się do dwóch, trzech sztuk, wśród których można wymienić: żupany, kontusze, szarawary, spódnice, suknie, kożuchy, siermięgi i in. Bielizna ip ościel zajmuje niewielką pozycję wśród przekazywanych ruchomości codziennego użytku. Wyliczyło je w testamencie zaledwie 7 testatorów. Szczególnie dużo strojów wymieniono w 5 testamentach. Maryna Fandenbergowa wymienia łącznie 13 sztuk odzieży i ogólnie chusty. Kazimierz Ćwiklicz 9 sztuk i ogólnie suknie. Były to dość wartościowe przedmioty, wykonane $z$ drogich materiałów (falendysz, jedwab, adamaszek, aksamit), często podszyte futrami, wśród których wymienić można czamarę kanawcową czarną, podszytą kunami, a druga lisami, czarny płaszcz falendyszowy podszyty lisami, nowy, czarny, półczamarek jedwabny. popielicami podszyty (nr 4) kontusz aksamitny rysiami podszyty, czapka aksamitna sobolowa (nr 32). Anastazja Pietkiewiczowa wymienia 9 ubiorów, są to jednak rzeczy, jak sama testatorka je określa "stare", jednak również wykonane $\mathrm{z}$ droższych materiałów (gradytur) i podszyte futrami (nr 65). Dwie inne testatorki wymieniają znaczenie inniej odzieży, Zofia Ćwikliczowa 6 sztuk (nr 28), zaś Marianna Badarkowa wymienia i opisuje tylko trzy ubiory. Warto na nie jednak zwrócić uwagę, ponieważ, były to tylko cenniejsze stroje, które wymieniła. „Parę sukien moich ponsowych gredyturowych z garniturem srebrnym obłożonych, synowi mojemu najukochańszemu Ignacemu z Paszkiewiczów Badarakiemu leguję i zapisuje. Suknią moją ciemną lamową bogatą ze srebrem do ołtarza Bractwa Trójcy Przenajświętszej zapisuje" - zeznaje testatorka ( $\mathrm{nr} 54$ ). Wymienia również ogólnie „inne suknie", które wraz z innymi elementami gierady tj. klejnotami, złotem, srebrem, cyną, miedzią zapisuje małżonkowi i synowi (nr 54). Gieradę wspominała również inna testatorka: $O$ tę cześć ruchomości wniesionąw posagu i uzupełnioną za życia mogły upominać się krewne, jeśli testatoraka nie pozostawiała po sobie potomków płci żeńskiej ${ }^{81}$. Cecylia Lewoncowiczowa zeznała, że przekazuje siostrze, ,żeby nie turbowała małżonka me-

81 B. Groicki, Artykuly prawa magdeburskiego, s. 10. 
go o gieradę, której mało co jest, tedy zł 10 pieniędzy małżonek mój ma dać jej. Do tego suknię moje falendyszową lazurową, kabat sztamentowy, fartuch..." (nr 31). Nie przestrzegano w testamentach grodzieńskich zasady przekazywania niewieścich pozostałości wyłącznie potomkom płci żeńskiej. Pojęcie gierady oprócz dwóch opisanych przypadków nie pojawia się więcej.

Ubiory były też przedmiotem zastawów. Mateusz Masłowski zeznał, że pożyczył 50 zł za co wziął zastaw: suknię atłasową, i półczamarek atłasowy (nr 45).

Nieznaczną pozycję zajmują w testamentach meble. Wymieniło je tylko 11 testatorów nie wyszczególniając ich w zasadzie. Wyjątkiem jest zapis Maryny Fandeberkowej, która szczegółowo wymieniła rzeczy znajdujące się w sypialni. Najważniejszą pozycję zajmowało w niej lóżko z baldachimem, które jak zeznała autorka kosztowało 30 talarów. Wymienia też szczegółowo pościel: 5 pierzyn, 8 poduszek „z powłóczkami białemi”. Ściany obite były 4 kilimami, oprócz tego wymienia zwierciadło i obrazy (nr 3). Nieduża liczba testamentów, w których wymienia się meble, nie musi świadczyć o ich braku w mieszkaniach grodzieískich mieszczan. Zapewne, jak zauważyła Urszula Sowina, było to wynikiem wybiórczego charakteru tych dokumentów ${ }^{82}$. Należy zauważyć, że wymieniane meble należały do kosztownych i zapewne $\mathrm{z}$ tego powodu zostały wyszczególnione. Inne zapewne przekazywane były spadkobiercom jako wyposażenie domu, którego nie dzielono pomiędzy spadkobierców.

Nieznaczną pozycję w testamentach zajmują również: klejnoty, srebro, złoto, cyna i miedź, jak również gotówka. Złoto i srebro odnotowano w 12 testamentach, cynę i miedź w 13 . Czasami były to pojedyncze przedmioty, niektórzy wyliczali jednak całkiem spore zasoby tych ruchomości. Maryna Fandebergowa wymieniła szczegółowo przedmioty ze srebra, cyny, miedzi i mosiądzu: „łyżek srebrnych jest 11, ośm doma, a łyżek 3 u P. Marcina Fandeberka, na które nic nie winno... pas srebrny złocisty i nożenki przy nim i czareczka do gorzałki... cyny półmisków przystawek tuzinów 3, talerzów cynowych tuzinów 2, garców cynowych z półgarcówkami i z kuflami sztuk ośm... kotłów miedzianych 2 po półtora cebra, a trzeci w ceber jeden, panewek wielkich 3 , a małych 2 , kociołek mały mosiężny szósty niewielki... lichtarzów cynowych 10 , mosiądzowych 2 , jeden niewielki a drugi ze dzwonkiem i nalewka z miednicą cynową prawda, durszlak karasek, 
tartka, szczypce mosiądzowe i miednica jedna mosiądzowa do umywania rąk i moźdz[i]erzyk mosiądzowy z tłuczkiem". Najbardziej wartościowe przedmioty znalazły się w testamencie wspominanego wcześniej Kazimierza Ćwiklicza. W zasadzie wymienia on całą listę drogocennych rzeczy. O klejnotach przekazanych na rzecz dalszych krewnych pisałam powyżej, wśród zaś rzeczy przekazanych zonie i córce warto wymienić: wstęgę z 21 diamentami, łańcuszek złoty o wartości 18 czerwonych zl, pierścień z diamentem i 6 rubinami, szablę wysadzaną turkusami, wartą $300 \mathrm{zl}$ wymienia on również w testamencie 15 grzywien srebra oraz nieokreśloną ilość cyny (nr 32).

Warto zwrócić uwagę na dość często pojawiające się stwierdzenie: „Ruchomości żadnej we srebrze i w złocie nie było" (nr 25), które miało najprawdopodobniej zapobiec ewentualnym roszczeniom spadkobierców.

Kończąc dyspozycje majątkowe przechodzono do wyznaczenia egzekutorów testamentu i opiekunów dla pozostałych członków rodziny. W testamentach mieszczan grodzieńskich uczyniono tak w 35 dyspozycjach (w 24 na 42 testamenty z XVII w. i 11 na 39 z XVIII w.).

Miało to miejsce zazwyczaj gdy pozostałą przy życiu była wdowa, często $\mathrm{z}$ małoletnimi jeszcze dziećmi lub sprawy majątkowe były skomplikowane, wierzytelności duże i trudne od odzyskania. Najczęściej wyznaczano ich spośród urzędników miejskich. W XVII wieku byli to: ławnicy (często obecni przy sporządzaniu testamentu), burmistrzowie, rajcy, pisarze, landwójci, przedstawiciele cechów (jeśli testator był jego członkiem), również osoby pochodzenia szlacheckiego, często też krewni: brat, teść, stryj, szwagier), sąsiedzi, raz ksiądz. W XVIII w. z listy egzekutorów i opiekunów znikają zupełnie lawnicy i przedstawiciele rodziny. Testator wyznaczal zazwyczaj dwie lub trzy osoby, wyjątkowo mniej np. jedną lub więcej np. cztery lub pięć.

Z formalnego punktu widzenia egzekutorzy testamentu i opiekunowie to różne osoby. Podzial ten respektowano jednak wyjątkowo. Teresa Wolkowa wyznaczyła dwóch egzekutorów testamentu i dwóch opiekunów dla syna (nr 51). Podobnie Bartłomiej Ćwikła wyznaczył egzekutora testamentu i opiekuna. W dwóch innych przypadkach wyznaczono tylko egzekutorów testamentu (nr 31,73), w czterech zaś wykonawcy ostatniej woli i opiekunowie to te same osoby ( $\mathrm{nr} 32,47,77,78)$. Wynika z powyższych danych, że rzadko wyznaczano egzekutorów (8 przypadków). Znacznie częściej pojawiają się opiekunowie, którym powierza się wykonanie dyspozycji testamentowych. W dwóch dyspozycjach opiekunowie nie zostali wyznaczeni formalnie i bezpośrednio. W testamencie Wojciecha Borysewicza rzeźnika czytamy, że żonę „bracia w niedostatku i ubóstwie jej ratować mają, a gdy Pan Bóg 
ostatni kres jej naznaczy, tedy pogrześć ciało mają, o co upraszam i powtóre ich" (nr 17) ${ }^{83}$.

$\mathrm{Na}$ końcu testamentu zamieszczano błogosławieństwo dla pozostałych członków rodziny, prośby i nakazy o zgodne współżycie oraz respektowanie i nie sprzeciwianie się postanowieniom testamentowym autora, połączone z groźbą wyrażaną za pomocą dość stereotypowego: „jeśliby kto nad ostatnią wolę moją chciał co czynić będzie, winien będzie Sądu Bożemu, na który go zapozywam" ( $\mathrm{nr} 46$ ). Zamieszczano również prośby skierowane do opiekunów, aby małżonki, dziatek nie pozwolili krzywdzić „pomniąc na ukrzyżowanego Pana onym radą i pomocą chcieli być" (nr 21). Charakterystycznym elementem było pożegnanie $\mathrm{z}$ członkami rodziny, sąsiadami przyjaciółmi, połączone $\mathrm{z}$ prośbą o wybaczenie win, krzywd i urazów, z zapewnieniem, że testator już to uczynil. Można odnieść wrażenie, że testator przedstawiał siebie jako człowieka, którym chciałby być, „lepszego człowieka", czyli de facto obraz odbiegający od rzeczywistości ${ }^{84}$. W ostatnich słowach bardzo często testator prosil, aby pamiętano o jego duszy, aby zamawiano Msze Święte w jego intencji, również innych zmarłych członków rodziny. Spotykamy też bardziej indywidualne prośby dotyczące przyszłości dzieci. Jan Chackiewicz Wołk chcial, aby żona córce jego „Połosi dała wychowanie i ćwiczenie, aby przy niej zostawała do wzrostu lat, a córkę napominan i błogosławieństwem rodzicielskim zobowiązuję, aby tak szanowal jako matkę własną swą" (nr 9). Podobnie Wojciech Hadyk zobowiązal żonę aby córce należyte jej stanowi wychowanie i edukację zapewniła ( $\mathrm{nr} 75)$. O edukacji syna wspomina również inny $\mathrm{z}$ testatorów (nr 80). Część omówiona wyżej łącznie wystąpiła w 47 testamentach w różnej formie. W XVII wieku tylko w 15 przypadkach. Znacznie częściej, w formie zawierającej wszystkie wymienione części, stając się niemal regułą w XVIII wieku ${ }^{85}$.

83 Również w testamentach pabianickich tylko 13 razy wyznaczono egzekutorów i jednocześnie opiekunów. H. Żerek-Kleszcz (op. cil., s. 46) wymienia kolejno: członków rodziny, duchownych, członków rady miejskiej, sįsiadów. Czy podana kolejność jest odzwierciedleniem częstotliwości? W testamentach sieradzkich na wykonawców (egzekutorów) wyznaczano najczęściej członków władz miejskich, rodzinę (spadkobierców), dłużników, przedstawicieli cechów, do których należał testator; duchownych, tylko w przypadku testamentów, które powstały w czasie zarazy. Wielu świadków, było jednocześnie wykonawcami testamentów. Tych ostatnich nie wyznaczono tylko w dwóch testamentach (U. Sowina, op. cit., s. 22-23).

84 Zwrócono już na to uwagę (М. Гардзеey, Н. Сліж, op. cit., s. 94).

85 Ta część formularza nie została omówiona w materiale porównawczym. 
Podanie daty, miejsca i podpisy testament zamykały. O świadkach stwierdzających wiarygodność testamentu mówiono już wcześniej. Jeśli zaś chodzi o datę i miejsce, nie przestrzegano podanej kolejności. W testamentach z XVII w. umieszczano je często na początku dokumentu, czasami dodatkowo również na końcu. W XVIII wieku w zasadzie regularnie już na końcu dokumentu. Datę podawano słownie rozpoczynając od roku, miesiąca i dnia. W przeciwieństwie do testamentów sieradzkich nie spotkałam się $\mathrm{w}$ analizowanym zbiorze $\mathrm{z}$ podaniem godziny sporządzania dokumentu ${ }^{86}$.

\section{Kto spisywał testamenty?}

W analizowanym zbiorze XVII-wiecznych testamentów niezwykle trudno określić - kto spisywał dyspozycje ostatniej woli. Ponieważ czynności te leżały w kompetencjach wójta i lawy, wydawałoby się, że najbardziej kompetentną i właściwą osobą byłby $w$ tej mierze pisarz ławniczy. Trzy razy odnotowano co prawda obecność pisarza radzieckiego. Jednakże w jednym przypadku wyraźnie stwierdzono, że sytuacja ta miała miejsce w związku z nieobecnością pisarza lawniczego ( $\mathrm{nr}$ 30). Drugi przykład dotyczy testamentu pisarza ławniczego Pawła Worobiejowicza, który podczas sporządzania testamentu, na tyle źle się czuł, że nie był nawet w stanie się podpisać (nr 10). W trzecim zaś jako świadkowie testamentu pojawiają się zarówno pisarz wójtowski jak i lawniczy (nr 32).

Analizowany zbiór testamentów XVII-wiecznych jednak nie pozwala stwierdzić, że osobą sporządzającą je był pisarz wójtowski, bardzo rzadko bowiem pojawia się on w dokumentach ostatniej woli.

Z sytuacją jasną mamy do czynienia wówczas gdy wyraźnie stwierdza się „...przydany przy panach lawnikach do tego testainentu napisania Aleksander Drogosz pisarz lawniczy" (nr 16). Dwa razy wspomniano tylko o obecności pisarza, nie wymieniając go z imienia i nazwiska, forma gramatyczna świadczy jednak, że to właśnie on testament spisywał np. „...Sąd gajny potrzebnie był zagajony $w$ domu P. Kaspra Bogdanowicza tkacza grodz[ieńskiego] i był odprawiony przez szlachetnych PP Adama Ćwiklicza, Wojciecha Piotrowskiego ławników i przy bytności Fiodora Jurewicza ławnika i mnie pisarza lawnicze[g]o roku..." (nr 5). Testament ten sporządzono w lipcu 1644 r. Porównanie go z trzema innymi, z których jeden powstal 
w tym samym roku (nr 4), i dwoma z 1640 r. (nr 2, 3) pozwala stwierdzić, że spisywała je ta sama osoba - pisarz miejski Mateusz Pitransewicz (Pietrancewicz). 'Testamenty z 1640 r. są niemal identyczne i rozpoczynają się charakterystyczną formułą stwierdzającą poczytalność testatora: „Zastana będąc, testarix na imic̨ [...], na pościeli chora, ale na umyśle i baczeniu swy $[\mathrm{m}]$ barzo dobrze zdrowa, chcąc ubogą majętność swoja rozporządzić, nie inaczej jeno tak...” Kończą się zaś stwierdzeniem, że „tak a nie inaczej chcąc mieć ten testament zawarła...".

We wszystkich czterech porównywanych testamentach powtarza się charakterystyczna formuła „taż testarix”, oraz polecenie duszy Bogu, w Trójcy Jedynemu, Marii i Wszystkim Świętym w tej samej z zasadzie kolejności. Podobnej analizie podałam 28 testamentów pochodzących $\mathrm{z}$ lat 1659-1677, kiedy urząd pisarza wójtowskiego pełnił Aleksander Drogosz ${ }^{87}$. Jego nazwisko pojawia się tylko w pięciu $\mathrm{z}$ nich i to $\mathrm{w}$ różnym charakterze. Porównanie wszystkich testamentów sporządzonych w tym okresie nie pozwala ustalić jakiegoś jednolitego formularza czy schematu, według którego byłyby sporządzane. Możliwe oczywiście, że ten sam pisarz stosował różne formuły, w zależności od okoliczności, statusu społecznego osoby testatora czy jego upodobań. Zauważone jednak podobieństwa pomiędzy analizowanymi wcześniej testamentami w postaci charakterystycznych zwrotów czy wyrażeń używanych przez pisarza, raczej wykluczają możliwoość, że testamenty te sporządziła jedna osoba.

Czasami $\mathrm{w}$ testamencie wymienia się pisarza wójtowskiego $\mathrm{z}$ imienia i nazwiska, lecz nie ma całkowitej pewności, że to on go sporządził. Wyraźnie się o tym bowiem nie mówi, a podaje go jako np. jednego ze świadków lub wyznacza jako opiekuna.

Tylko w nielicznych więc przypadkach możemy twierdzić, lub podejrzewać, że spisywał testament pisarz. Możliwe jest również, że obecność pisarza jako rzecz oczywista, naturalna nie została odnotowana. Zazwyczaj można jedynie stwierdzić, że przy wysłuchaniu ostatniej woli obecni byli dwaj ławnicy czasem inni urzędnicy.

Bardzo prawdopodobne wydaje się, że to właśnie ławnicy spisywali akty ostatniej woli. Interesujące $w$ tym przypadku wydają się testamenty, przy których sporządzaniu obecny był tylko jeden lawnik. Testatorka Jadwiga Janucikowa wyraźnie stwierdziła, że „nie będąc pisma umiejętna, ani

87 J. Hardziejeŭ, Przyczynek do dziejów kancelarii miejskich grodzieńskich w XVIXVIII w., „Białostocczyzna” 2001, nr 1-2, s. 5. 
nie mając żadnego sąsiada, który by pisma umial do tejże swojej dispositij, mnie ławnika o podpis ręki prosiła" (nr 23). Innym przykładem, który według mnie warto omówić, jest testament Jan Chackiewicza Wołka, sporządzony w obecności lawnika Piotra Lewkowicza (nr 9) oraz jego własny testament sporządzony dwa lata później (nr 13). Oprócz inwokacji, która pojawia się w testamencie Chackiewicza (unity), pod względem formalnym oba testamenty niczym się nie różnią. Brak adnotacji w obu przypadkach o obecności pisarza, pozwala domniemywać, że spisywał je Piotr Lewkowicz, w pierwszym przypadku jako lawnik, w drugim zaś, sam będąc testatorem, sporządzil go własnoręcznie, aczkolwiek tego wyraźnie nie stwierdził.

Można by domniemywać również, że skoro przy sporządzaniu testamentów i podawaniu do akt obecne były te same osoby, na miejscu, nie powstawały one w ostatecznej formie, a jedynie w formie skrótowych zapisów, które były następnie rozbudowywane przez pisarza miejskiego.

Zupełnie inaczej sygnalizowany problem przedstawia się w testamentach z XVII I w. Jak już wspomniano, to właśnie osoba pisarza najczęściej była urzędowym świadkiem testamentu. Podpis pisarza, podobieństwo formalne dokumentów nie pozostawia wątpliwości, że spisującym dokument był podpisujący się pisarz. Porównanie jednak 9 testamentów spisanych przez Mikoła ja Michała Szarkowskiego - pisarza radzieckiego ( $\mathrm{nr} 47,48,54,58$, $59,53,51,52,56)$ i 8 przez Jana Kazimierzowicza - pisarza wójtowskiego (nr 61, 62, 63, 64, 66, 67, 60, 55) pozwala zauważyć, że ten drugi wyraźnie wzorował się, korzystał $\mathrm{z}$ gotowych i dostępnych formularzy (jednak identycznych z tymi, z których korzystał Szarkowski). Takich formularzy istniało być może więcej, kolejni bowiem pisarze pojawiający się w testamentach nie wzorowali się na formularzach stosowanych przez Szarkowskiego i Kazimierzowicza, ani też nie stosowali jakiegoś jednego i charakterystycznego wzoru. Istnienie gotowych formularzy, na których wzorować się mogli spisujący testament, poddaje w wątpliwość zasadność porównywania dokumentów, (jeśli nie odnotowano osoby pisarza) i na tej podstawie stwierdzenia jego autorstwa. Oczywiście spisujący nie musiał wiernie kopiować wzoru. Wprowadzane przez niego modyfikacje, w postaci np., charakterystycznych zwrotów czy wyrażeń, charakterystyczna kolejność formuł i części testamentu - upoważniają do stwierdzenia jego tożsamości (np. cztery wcześniej analizowane testamenty z XVII wieku).

W analizowanym zbiorze testamentów raz odnotowano, że osobą, która napisała testament, był testator. Nie stwierdził on jednak tego osobiście. Informacja ta podana została niejako przypadkiem w formule aktykacyjnej (nr 46). Raz również wyraźnie zaznaczono, że ławnicy zostali wezwani, do 
wysłuchania i urzędowego potwierdzenia ostatniej woli, którą spisał ksiądz Gabriel Grochowski (nr 33). Być może testament powstał już wcześniej, a ławnicy mieli potwierdzić jego prawomocność, lub był sporządzany w czasie jego zeznawania.

Warto też nadmienić o dość interesującej, według mnie, kwestii dotyczącej określenia, na ile testament rzeczywiście był tekstem oryginalnym, tzn. podyktowanym przez samego aktora, a na ile była to ingerencja osób trzecich, np. spisujących testament. W większości bowiem przypadków wystawcy byli ludźmi niepiśmiennymi, sami więc na pewno dyspozycji nie pisali. Większość testamentów napisana jest w pierwszej osobie, niektóre w trzeciej, i wtedy mamy do czynienia, jakby z relacją świadka, który ostatniej woli wysłuchal. Interesujące są testamenty w których wyraźnie widać, co pochodzi od testatora, a co od osoby piszącej, zmienia się bowiem trzecioosobowy charakter narracji na pierwszoosobowy. Spisujący testament zapisuje pytania, jakie zadaje aktorowi. Dotyczyły one: dobrowolnej chęci zeznania testamentu (nr 11); ogólnego pytania, jak i komu chciałby przekazać swój majątek (nr 39); długów: „komu by co winna pytana zeznała” lub „jej kto winien odpowiedziała” (nr 2 również podobnie $\mathrm{nr} 15$ ). Zadając pytania spisujący testament niejako sugerowal, co w testamencie powinno się znaleźć. Zapisywano nie tylko pytania, ale również uwagi lub protesty osób będących przy sporządzaniu testamentu. Wierzyciele upominali się o długi, do których testator nie przyznawał się. Maryna Hanusowa Fandenberkowa ( $\mathrm{nr}$ 3) w trzy dni po sporządzeniu testamentu, po spowiedzi i komunii, po raz drugi wzywając lawników, potwierdziła długi. Mikołaj Gudajewski (nr 19) również niejako zapomniał o swoich długach. Poszkodowani wnieśli swoje pretensje już po śmierci testatora, będąc obecni przy odczytaniu i podaniu testamentu do akt. Ich uwagi zapisano pod tekstem testamentu ${ }^{88}$.

W dyspozycji Wojciecha Borysowicza (nr 17) odnotowano, że żona zgadza się $\mathrm{z}$ wolą męża i przyrzekła ją wypełnić. Fiedor Borsukiewicz (nr 14) zarzucał wprost żonie, że roztrwoniła majątek, nie chciała z nim mieszkać, „lubiła wypić” i otruła go. W związku z tym nie zapisał jej niczego. Żona, obecna przy spisywaniu testamentu nie zgadzała się z jego decyzją, twier-

88 H. Żerek-Kleszcz, op. cit., s. 39. Autorka również zauważyła, że testamenty służyły do urzędowego potwierdzenia długów, które były przedmiotem umów ustnych. W testamentach zapisywano również długi, które były pisemnie potwierdzone jak i te już uregulowane. Rzadko co prawda, ale zdarzało się, że testator nie był zadłużony, co również odnotowywano. 
dząc, że swoim kosztem postawiła budynek, który spłonął podczas wojny z Moskwą. Mąż jednym zdaniem skwitował pretensje żony: „a cóż temu rzec, że Moskwa spaliła" - przecież to nie jego wina. W testamencie Katarzyny Polczanki Aleksandrowej Karłowskiej (nr 11) odnotowano protesty „męża, który przy bytności naszej oną począł hałasować mówiąc, co tobie po tym. Onej nie chciał pozwolić, która będąc już bliska śmierci przed nami tak powiedziała: miły mężu, ja się do twojej majętności nie chcę tykać lubo ze mną nabyta, tylko cię o to proszę, ażeby ten plac mój własny dziatkom moim, [zięciowi i córce] a nie komu inszemu należal, który na to [wszy]tko zezwolil, obiecując jeszcze na tym placu budynek postawić i tym dać jako dziatkom swoim przy sporządzaniu testamentu" (nr 11). Aleksander Karłowski (nr 22) obietnice swoją spełnil, i 6 lat później w testamencie zapisał im plac na ul. Wileńskiej $\mathrm{z}$ budynkiem. $\mathrm{Z}$ jego $\mathrm{z}$ kolei dyspozycjami nie zgadzała się obecna żona, twierdząc: „że ją nie tak jak małżonkę odprawował i legowal grunt".

Spisywanie testamentu $\mathrm{w}$ trzecioosobowej narracji, wprowadzanie do tekstów testamentów uwag postronnych osób będących przy zeznaniu ostatniej woli sprawia, że testament staje się niejako relacją, sprawozdaniem czy też „urzędowym protokołem zdarzeń" ${ }^{89}$. Warto zwrócić uwagę, że właśnie te testamenty najbardziej nacechowane są indywidualnym charakterem. 'Taki sposób zapisania testamentu zanikł zupełnie w XVIII wieku. Wszystkie testamenty spisywano $\mathrm{w}$ pierwszej osobie, w żadnym też nie odnotowano komentarzy czy uwag osób trzecich. Warto porównać kilkanaście dokumentów, które powstały w stosunkowo krótkim okresie i spisane zostały przez tę samą osobę. Są to akty ostatniej woli, pod którymi podpisali się: w 9 testamentach Mikołaj Michał Szarkowski (nr 47, 48, 54, 58, 59, 53, 51, 52, 56) i 8 Jan Kazimierzowicz ( $\mathrm{nr} 61,62,63,64,66,67,60,55)$. Identyczne inwokacje, arengi, powierzenie duszy sformułowane w każdym przypadku identycznie, pożegnanie członków rodziny, prośba o przebaczenie, błogosławieństwo znowu zapisane według jakiegoś jednolitego szablonu, upoważnia do stwierdzenia, że wszystkie te części testamentu pochodziły od pisarza. Forma zapisu proponowana przez zapisującego aprobowana była zapewne przez testatora. Warto wspomnieć, że określenia „miła małżonka”, „najukochańszy syn", jeśli pochodzą z testamentów sporządzanych przez jednego, zidentyfikowanego pisarza, wcale nie muszą być rzeczywistym obrazem stosunków łączących wzmiankowane osoby. Po prostu pisarz miał taką manierę i w ta- 
ki sposób relację zapisywał90 ${ }^{90}$ Jeśli taką wersję przyjmiemy, to testament straci po części swój indywidualny charakter. Stanie się typem dokumentu, sporządzanego według określonych schematów. Nie we wszystkich zapewne testamentach ingerencja posunięta była aż tak daleko.

\section{Podsumowanie}

Analizie powyższej poddano 81 testamentów mieszczańskich. Było to zajęcie bardzo pracochłonne. W literaturze przedmiotu nie spotkałam się dotychczas $\mathrm{z}$ tak obszernym omówieniem tego typu materiału źródłowego. Prezentacja powyższa miała na celu ukazanie specyfiki dokumentacji testamentowej, sposobu jej powstawania, dlatego szczegółowo zostały omówione poszczególne części tych dokumentów. Analizując treść dyspozycji ostatniej woli mieszczan grodzieńskich możemy dowiedzieć się: kim byli autorzy; jaką funkcję czy zawód pełnili; jakiego byli wyznania; gdzie chcieli być pochowani i jaką wagę przywiązywali do spraw religijnych; jakim majątkiem dysponowali; jak wyglądały stosunki rodzinne, czyli komu i co zapisywano w spadku ${ }^{91}$.

Testamenty mieszczan grodzieńskich $\mathrm{z}$ lat 1640-1796, jak wykazano powyżej, sporządzane były według określonego schematu, podobnie jak poddane analizie źródłoznawczej testamenty mieszczan sieradzkich, pabianickich czy kieleckich. W Grodnie w większości przypadków: zeznawano je przed urzędem wójtowsko-ławniczym, w XVIII wieku również przed urzędem radzieckim. $\mathrm{Z}$ reguły sporządzano je $\mathrm{w}$ domu testatora, zazwyczaj krótko przed śmiercią. Warto przypomnieć, że w przypadku niepiśmiennych autorów, wiarygodność dokumentu potwierdzano uściskiem dłoni. Niezmiernie trudno jest odpowiedzieć na pytanie - kto spisywał testamenty. Mógł to być pisarz lawniczy, ale do rzadkości w XVII wieku należy wyraźne stwierdzenie tego faktu. Odnotowywano jedynie, że przy sporządzaniu testamentu obecni byli lawnicy i to oni prawdopodobnie testamenty spisywali. Dużo jaśniej przedstawia się ten problem w następnym stuleciu. Wówczas to pisarz najczęściej występował jako urzędowy świadek testamentu. Tylko raz

90 M. Borkowska (op. cit., s. 15) uważa, że tego typu zwroty pojawiające się w testamentach, były normalnymi, i należnymi rodzinie tytułami.

91 Kwestie religijne w porównaniu z dyspozycjami majątkowymi zostały omówione w niniejszym artykule pobieżnie. Jest to jednak tak obszerny materiał, że chciałabym poświęcić tej kwestii odrębną publikację. 
odnotowano, że testator sam spisał ostatnią wolę. W świetle analizowanego materiału podejrzewać można, że przynajmniej kilku członków patrycjatu postąpiło podobnie.

Wykonawców testamentu wyznaczono tylko w 31 przypadkach. Byli to zazwyczaj urzędnicy miejscy, którzy mieli zająć się skomplikowanymi sprawami majątkowymi, często odzyskaniem długów.

W analizowanym zbiorze na uwagę zasługują zachowane oryginały testamentów, które należą do rzadkości.

Wśród 81 testamentów - 22 dokumenty zostaly sporządzone przez członków patrycjatu. Są też testamenty rzemieślników, kupców, aptekarza oraz mieszkańców wsi miejskich. Ich dokładny wykaz odnajdzie czytelnik w dołączonym aneksie. Autorzy wywodzili się z różnych środowisk. Nie tylko przedstawiciele elit sporządzali testamenty.

Autorzy w większości byli rzymskimi-katolikami. Dyspozycje pogrzebowe, będące jedną $\mathrm{z}$ części testamentu, nie były szczegółowe. Wyznaczano osobę, która miała zająć się oprawą pogrzebu, sumę, za którą miał być odprawiony, miejsce pochówku, proszono też o Msze Św. Bardzo rzadko przeznaczano gotówkę - najczęściej nakazywano sprzedać część majątku lub kosztami pogrzebu obarczani byli spadkobiercy. Nie we wszystkich jednak testamentach pojawiają się dyspozycje pogrzebowe. Sprawy doczesne - majątkowe, ich uregulowanie i zabezpieczenie przed ewentualnymi roszczeniami i konfliktami pomiędzy spadkobiercami - to główna przyczyna sporządzania testamentów. Ilość zapisów na cele religijne wydaje się potwierdzać tę tezę. Tylko 27 autorów na 81 przekazało fundusze na cele religijne - pieniądze, grunt, odzież, naczynia. Do rzadkości należało przekazywanie gotówki - zazwyczaj były to długi, które obdarowani mieli wyegzekwować. Z drugiej strony spadkobiercy nie spieszyli się $\mathrm{w}$ wywiązaniem się $\mathrm{z}$ należnych kościołom zapisów, zlecając ich wykonanie swoim spadkobiercom.

'Trudno zaprzeczyć, że testament był przede wszystkim dyspozycją majątkową. Z drugiej strony religijna część testamentu, występująca w większości opisywanych dokumentów, nawet jeśli przyjmiemy, że na ich powstanie duży wpływ miały osoby trzecie, czyli obecni przy sporządzaniu urzędnicy miejscy, i że powstawały one według określonego schematu, jest zapewne świadectwem religijności i pobożności autorów testamentów. Aprobowali ten schemat i zgadzali się z nim, nawet jeśli nie byli autorami inwokacji czy areng.

Umierający chciał zabezpieczyć żonę i przekazać majątek dzieciom. Jeśli były małoletnie, działu miał dokonać w przyszłości pozostały współmałżonek. Dorosłym potomkom dokładnie wydzielano przypadające na nich 
części ruchomości i nieruchomości. Z analizy testamentów wynika, że starano się dokonywać równych działów majątkowych. Nieliczne odstępstwa dotyczą uprzywilejowania synów względem córek, zarówno w podziale nieruchomości, jak i przyınania córkom jedynie ruchomości. Zdarzało się, że jeden $\mathrm{z}$ potomków bez względu na płeć, $\mathrm{z}$ moralnych przyczyn został $\mathrm{w}$ testamencie uprzywilejowany. Dalszą rodzinę uwzględniano w testamentach rzadko. Były to zazwyczaj wnuki, a inni członkowie rodziny sporadycznie. Nie dotyczy to oczywiście małżeństw bezdzietnych. Ci przekazywali równie często majątek współmałżonkowi jak i pozostałym krewnym - zazwyczaj dzieciom brata lub siostry.

Najbardziej znaczącą pozycję wśród przekazywanego majątku stanowiły grunty uprawne. Tego typu zapisów dokonano w $69 \%$. Nie musi to jednak oznaczać, że mieszkańcy Grodna trudnili się rolnictwem. Najwięcej ziemi znajdowało się w posiadaniu patrycjatu oraz mieszkańców wsi miejskich. W XVIII wieku wielkość przekazywanego areału uprawnego znacząco maleje. O ile w XVII w. 5 autorów przekazało swoim spadkobiercom powyżej trzech włók ziemi, to w XVIII w. zdarzyło się to tylko raz. Podobnie rzecz wyglądała z działkami miejskimi, które w XVII wieku często wchodziły w skład przekazywanego majątku. W następnym stuleciu ilość przekazów wyraźnie spadła i do rzadkości należeli autorzy, którzy byliby właścicielami większych posesji.

Wśród nieruchomości największą pozycje stanowią zwierzęta. Na 56 posiadaczy gruntów miejskich wymieniło je jednak tylko 33. Wielkość przekazywanego inwentarza była bardzo zróżnicowana. Obok testatorów, którzy przekazywali nawet do 50 sztuk różnego inwentarza, choć ci należą do rzadkości, wcale często spotykamy się z zapisami 2-3 sztuk.

Kolejnym, najczęściej odnotowanym, składnikiem nieruchomości była odzież. Tylko kilku testatorów przekazało znaczną liczbę odzieży, często drogocennej, wykonanej z drogich materiałów i skór. Zazwyczaj wymieniano 2-3 sztuki ubrań.

Grodzieńscy autorzy testamentów rzadko przekazywali w spadku złoto, srebro, cynę, miedź. Darowizny gotówki zdarzały się jeszcze rzadziej. Wyraźnic też widać, że ilość takich zapisów maleje w XVIII wieku. Uzasadniają to autorzy testamentów spustoszeniami, które nastąpiły po „potopie moskiewskim"

Warto zwrócić również uwagę na kwestię oryginalności zapisów testamentowych, tzn. na ile były to słowa samych autorów testamentów, a na ile była to ingerencja osób trzecich. Schematyczność większości zapisów testamentowych podważa fakt ich oryginalności. Dotyczy to przede wszystkim 
takich części testamentów jak inwokacja, arengi, polecenie duszy, pożegnanie się z członkami rodziny czy społeczności. Niewątpliwie jednak najbardziej interesujące są testamenty, do których wprowadzano uwagi osób trzecich, odnotowywano pytania, które autorom testamentów zadawali sporządzający je urzędnicy. W ich świetle często widać prawdziwe relacje międzyrodzinne.

$\mathrm{Na}$ zakończenie chciałabym zwrócić: uwagę, że testamenty $\mathrm{z}$ dużych ośrodków miejskich: Gdaríska, Krakowa, Warszawy od dawna cieszyły się zainteresowaniem historyków. Przeprowadzono również analizę źródłoznawczą aktów ostatniej woli mieszkańców mniejszych ośrodków miejskich Sieradza, Przemyśla, Pabianic. Publikacje te dotyczą jednak terenów Korony. $\mathrm{O}$ testamentach $\mathrm{z}$ terenu Wielkiego Księstwa Litewskiego wiemy zaś niewiele.

Aneks 1

Spis testamentów mieszczan grodzieńskich

\begin{tabular}{|c|c|c|c|c|}
\hline $\mathrm{Nr}$ & Imię i nazwisko & $\begin{array}{l}\text { Data } \\
\text { sporządzenia }\end{array}$ & $\begin{array}{l}\text { Data } \\
\text { aktykacji }\end{array}$ & Sygnatura, uwagi \\
\hline 1 & Iwan Siergiejewicz & 141111485 & 1633 & $\begin{array}{l}\text { AVAK, t. I, Wilno } 1865 \text {, cz. I, } \\
\text { nr } 16, \text { s. } 55-6\end{array}$ \\
\hline 2 & $\begin{array}{l}\text { Regina Gawlowiczowna } \\
\text { Janowa Przylucka }\end{array}$ & 7,10 II 1640 & 7,10 II 1640 & $\begin{array}{l}\text { NAHB w Mińsku, F. } 1761 \text {, op. } 1 \text {, } \\
\text { nr 1, k. } 129-130 \text { - oryginal }\end{array}$ \\
\hline 3 & $\begin{array}{l}\text { Maryna Siemienowna } \\
\text { lv. Piotrowa C.wikliczowa } \\
\text { 2v. Hanusowa Fandeberkowa } \\
\text { rajczyni }\end{array}$ & 27,29 III 1640 & po 29 III 1640 & $\begin{array}{l}\text { NAHB w Mirisku, F. 1761, op. } 1 \text {, } \\
\text { nr 1, k. 130v-132 }\end{array}$ \\
\hline 4 & $\begin{array}{l}\text { Hanna Toloczkowa } \\
\text { Fiedorowa Jurewiczowa } \\
\text { lawnikowa }\end{array}$ & 9 III 1644 & $27 \vee 1644$ & $\begin{array}{l}\text { NAHB w Mirísku, F. } 1761 \text {, op. } 1 \text {, } \\
\text { nr } 1 \text {, k. 276-276v }\end{array}$ \\
\hline 5 & $\begin{array}{l}\text { Kaper Bogdankiewicz } \\
\text { tkacz }\end{array}$ & 6 VII 1644 & 8 VII 1644 & $\begin{array}{l}\text { NAHB w Minisku, F. } 1761 \text {, op. } 1 \text {, } \\
\text { nr } 1 \text {, k. } 281 \mathrm{v}\end{array}$ \\
\hline 6 & $\begin{array}{l}\text { Dorota Burbianka } \\
\text { Tomaszowa Lagowska } \\
\text { wdowa po burmistrzu }\end{array}$ & $12 \vee 1657$ & 28 III 1659 & $\begin{array}{l}\text { L'AH w Wilnie, F. 1282, op. 1, } \\
\text { nr 4734, k. 1--2. - } \\
\text { Wypis z 15.V.1709 }\end{array}$ \\
\hline 7 & $\begin{array}{l}\text { Krystyna Wirbikowna } \\
\text { Andrzejowa Filipowiczowa } \\
\text { oraz Andrzej Filipowicz } \\
\text { mieszczanie z Baranowicz }\end{array}$ & $\times 1657$ & 20 IX 1660 & $\begin{array}{l}\text { NAHB w Mińsku, F. } 1800 \text {, op. } 1 \text {, } \\
\text { nr } 1 \text {, k. } 25 v-26\end{array}$ \\
\hline 8 & $\begin{array}{l}\text { Jan Fondelserg } \\
\text { lawnik }\end{array}$ & $22 \times I \quad 1657$ & 2 XII 1661 & $\begin{array}{l}\text { NAHB w Miísku, F. 1800, op. } 1 \text {, } \\
\text { nr 1, k. 52v- } \\
\text { Wypis z ks. dworu chodorow- } \\
\text { skiego aktykowany w ks. wój- } \\
\text { lowsko-lawniczych Grodna }\end{array}$ \\
\hline 9 & $\begin{array}{l}\text { Jan Chackiewicz Wolk } \\
\text { mieszczantin }\end{array}$ & 2 I 1659 & $26 \times 1659$ & $\begin{array}{l}\text { NAHB w Mińsku, F. } 1800 \text {, op. } 1 \text {, } \\
\text { nr } 1 \text {, k. } 13 v-14\end{array}$ \\
\hline 10 & $\begin{array}{l}\text { Pawel Worobiej } \\
\text { pisarz wójtowski, lawniczy }\end{array}$ & 16 VI 1659 & 21 VI 1659 & $\begin{array}{l}\text { NAHB w Mirísku, F. 1800, op. } 1 \text {, } \\
\text { nr 1, k. 6-7 }\end{array}$ \\
\hline
\end{tabular}


Agnieszka Pisanko-Borowik

\begin{tabular}{|c|c|c|c|c|}
\hline $\mathrm{Nr}$ & Imię i nazwisko & $\begin{array}{l}\text { Data } \\
\text { sporządzenia }\end{array}$ & $\begin{array}{c}\text { Data } \\
\text { aktykacji }\end{array}$ & Sygnatura, uwagi \\
\hline 11 & $\begin{array}{l}\text { Katarzyna Polczanka } \\
\text { (Pilczanka) } \\
\text { 2v. Aleksandrowa Karłowska } \\
\text { mieszczka z Karlowa }\end{array}$ & 18 IV 1660 & 711661 & $\begin{array}{l}\text { NAHB w Mińsku. F. 1800, op. 1, } \\
\text { nr 1, k. 41-41v }\end{array}$ \\
\hline 12 & $\begin{array}{l}\text { Jadwiga Nalęczowna } \\
\text { Toinaszowa Massnicka } \\
\text { wdowa, mieszczka } \\
\text { z Adamowicz }\end{array}$ & $171 \times 1660$ & $\begin{array}{l}\text { Między 8.X } \\
\text { a } 2 \text { XI } 1660\end{array}$ & $\begin{array}{l}\text { NAHB w Mirisku, F. 1800, op. } 1 \text {, } \\
\text { nr } 1 \text {, k. 30v }\end{array}$ \\
\hline 13 & $\begin{array}{l}\text { Piotr Lewkowicz } \\
\text { burmistrz }\end{array}$ & 19 XII 1661 & 6 II 1662 & $\begin{array}{l}\text { NAHB w Mińsku, F. 1800, op. 1, } \\
\text { nr 1, k. 58v-60v }\end{array}$ \\
\hline 14 & $\begin{array}{l}\text { Fiedor Borsukiewicz } \\
\text { mieszczanin grodzieriski } \\
\text { z Miol }\end{array}$ & 20 III 1663 & $\begin{array}{l}\text { Między } 25 \text { V } \\
\text { a } 31 \text { VIII } 1663\end{array}$ & $\begin{array}{l}\text { NAHB w Mirisku, F. } 1800 \text {, op. } 1 \text {, } \\
\text { nr } 1, \text { k. 76-77 }\end{array}$ \\
\hline 15 & \begin{tabular}{|l} 
Anna Kozlowszczanka \\
Hieronimowa Mleczkowa \\
syndykowa miejska \\
\end{tabular} & $18 \times 166.3$ & 18 VII 1664 & $\begin{array}{l}\text { NAHB w Mińsku, F. 1800, op. 1, } \\
\text { nr } 1 \text {, k. } 100 v\end{array}$ \\
\hline 16 & $\begin{array}{l}\text { Jerzy Streczeń } \\
\text { Inieszczanin z Adannowicz }\end{array}$ & 5 IV 1664 & 25 IV 1664 & $\begin{array}{l}\text { NAHB w Mirisku, F. 1800, op. 1, } \\
\text { nr } 1 \text {, k. } 91 \text { v }-92 v\end{array}$ \\
\hline 17 & $\begin{array}{l}\text { Wojciech Borysowicz } \\
\text { rzeźnik }\end{array}$ & $16 \vee 1664$ & $\begin{array}{l}\text { Między } 3 \text { a } 16 \\
\text { VII } 1671\end{array}$ & $\begin{array}{l}\text { NAHB w Mińsku, F. } 1800, \text { op. } 1 \text {, } \\
\text { nr } 1 \text {, k. } 218 v-219\end{array}$ \\
\hline 18 & $\begin{array}{l}\text { Maryna Iwaniszewiczówna } \\
\text { Sonoskowa Kraceniacina } \\
\text { mieszczka z Grandzicz? }\end{array}$ & 13 VI 1664 & 11 VII 1664 & $\begin{array}{l}\text { NAHB w Miŕsku, F. 1800, op. 1, } \\
\text { nr 1, k. 99v-100 }\end{array}$ \\
\hline 19 & \begin{tabular}{|l} 
Mikolaj Gudaiewski \\
rajca, wdowiec, mieszczanin \\
z Malachowicz \\
\end{tabular} & $4 \vee 1665$ & 12 VI 1665 & $\begin{array}{l}\text { NAHB w Mińsku, F. 1800, op. 1, } \\
\text { nr I, k. 116-117 }\end{array}$ \\
\hline 20 & $\begin{array}{l}\text { Tomasz Cuprykowski } \\
\text { krawiec, byly cechmistrz, } \\
\text { jurydyczanin farny }\end{array}$ & 15 I 1666 & $\begin{array}{l}\text { między } 26 \text { VI } \\
\text { a } 16 \text { VII } 1666\end{array}$ & $\begin{array}{l}\text { NAHB w Miŕsku, F. } 1800 \text {, op. } 1 \text {, } \\
\text { nr } 1 \text {, k. } 128 v-129\end{array}$ \\
\hline 21 & $\begin{array}{l}\text { Jan Adamowicz } \\
\text { rajca byly burmistrz }\end{array}$ & $2 \vee 1666$ & $14 \vee 1666$ & $\begin{array}{l}\text { NAHB w Miŕsku, F. 1800, op. } 1 \text {, } \\
\text { nr } 1, k .125-126\end{array}$ \\
\hline 22 & $\begin{array}{l}\text { Alexander Karłowski } \\
\text { lawnik, mieszczanin } \\
\text { z Mickiewicz } \\
\end{array}$ & 21 VIII 1666 & 27 VIII 1666 & $\begin{array}{l}\text { NAHB w Mirisku, F. } 1800, \text { op. } 1 \text {, } \\
\text { nr } 1 \text {, k. 130-130v }\end{array}$ \\
\hline 23 & $\begin{array}{l}\text { Jadwiga Janucikowa } \\
\text { mieszczka z Ćwiklicz }\end{array}$ & 1 III 1667 & 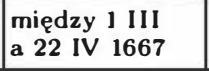 & $\begin{array}{l}\text { NAHB w Mirisku, F. 1800, op. 1, } \\
\text { nr } 1 \text {, k. } 140 v-141\end{array}$ \\
\hline 24 & $\begin{array}{l}\text { Stanislaw Przełucki } \\
\text { mieszczanin grodzieński }\end{array}$ & 4 VII 1667 & 4 VII 1667 & $\begin{array}{l}\text { NAHB w Mińsku, F. } 1800 \text {, op. } 1, \\
\mathrm{nr} 1 \text {, k. 145-145v - oryginal }\end{array}$ \\
\hline 25 & $\begin{array}{l}\text { Jerzy Szelpuk } \\
\text { inieszczanin }\end{array}$ & 8 VIII 1667 & \begin{tabular}{|l|} 
Między 26 VIII \\
a 1 X 1667
\end{tabular} & $\begin{array}{l}\text { NAHB w Mirisku, F. 1800, op. 1, } \\
\text { nr } 1 \text {, k. } 150\end{array}$ \\
\hline 26 & $\begin{array}{l}\text { Anna Jordanowna } \\
\text { Tobiaszowa Dorzbachowa } \\
\text { wdowa }\end{array}$ & 2 VI 1668 & $\begin{array}{l}\text { Między } 31 \text { VIII } \\
\text { a } 14 \text { IX } 1668\end{array}$ & $\begin{array}{l}\text { NAHB w Miŕsku, F. 1800, op. 1, } \\
\text { nr 1, k. 166-166v }\end{array}$ \\
\hline 27 & Anna Siemienowa Mikycina & 16 IV 1669 & $\begin{array}{l}20 \mathrm{~V} \text { a } 12 \mathrm{VII} \\
1669\end{array}$ & $\begin{array}{l}\text { NAHB w Miŕsku, F. 1800, op. 1, } \\
\text { nr } 1 \text {, k. 182-182v }\end{array}$ \\
\hline 28 & $\begin{array}{l}\text { Zofia Sikurska } \\
\text { Adamowa Cwikliczowa } \\
\text { ra jczyni }\end{array}$ & 16 VI 1669 & $\begin{array}{l}24 \text { I a } 14 \text { II } \\
1670\end{array}$ & $\begin{array}{l}\text { NAHB w Mińsku, F. } 1800, \text { op. } 1 \text {, } \\
\text { nr } 1 \text {, k. } 195 \mathrm{v}-196 \mathrm{v}\end{array}$ \\
\hline 29 & Piotr Ciborowski & 24 VII 1669 & $\begin{array}{l}4 \text { IX a } 11 X \\
1669\end{array}$ & $\begin{array}{l}\text { NAHB w Mińsku, F. 1800, op. } 1 \text {, } \\
\text { nr } 1 \text {, k. 189-- }\end{array}$ \\
\hline
\end{tabular}




\begin{tabular}{|c|c|c|c|c|}
\hline $\mathrm{Nr}$ & Imię i nazwisko & $\begin{array}{l}\text { Data } \\
\text { sporządzenia }\end{array}$ & $\begin{array}{l}\text { Data } \\
\text { aktykacji }\end{array}$ & Sygnatura, uwagi \\
\hline 30 & $\begin{array}{l}\text { Marianna Zyskiewiczowna } \\
\text { lv. Marcinowa Kolendzina } \\
\text { 2v. Malcherowa Piotrowiczowa } \\
\text { cechmistrzowa kotlarska }\end{array}$ & 26 IX 1670 & $\begin{array}{l}\text { między } 18 \text { III } \\
\text { a } 4 \text { dniem po } \\
\text { sw. Stanisławie } \\
1672\end{array}$ & $\begin{array}{l}\text { NAHB w Mińsku, F. } 1800 \text {, op. } 1 \text {, } \\
\text { nr } 1, \text { k. } 237 v-238 . \\
\text { I'o samo aktykowano NAHB } \\
\text { w Mińsku, F. } 1761 \text {, op. } 1 \text {, nr } 2 \text {, } \\
\text { k. } 285 \text { - }\end{array}$ \\
\hline 31 & $\begin{array}{l}\text { Cecylia Karlowska } \\
\text { 2v. Sebastianowa Lewoncewi- } \\
\text { czowa } \\
\text { mieszczka }\end{array}$ & 9 XI 1670 & 14 XI 1670 & $\begin{array}{l}\text { NAHB w Mirisku, F. 1800, op. } 1 \text {, } \\
\text { nr 1, k. 202v-203v }\end{array}$ \\
\hline 32 & $\begin{array}{l}\text { Kazimierz Ćwiklicz } \\
\text { rajca, wielokrotny burnnistrz } \\
\text { i landwójt }\end{array}$ & 15 I 1671 & $\begin{array}{l}\text { feria sexta post } \\
\text { D[omi]nica!l } \\
\text { Conducty } 1671\end{array}$ & $\begin{array}{l}\text { NAIHB w Miŕsku, F. 1800, op. } 1 \text {, } \\
\text { nr } 1, \text { k. } 21 \text { lv-215 }\end{array}$ \\
\hline 33 & $\begin{array}{l}\text { Lewon Zyskiewicz (Zysk) } \\
\text { mieszczanin z Przedmieścia } \\
\text { Zaniemcískiego }\end{array}$ & $20 \mathrm{~V} 1671$ & 3 a 16 VII 1671 & $\begin{array}{l}\text { NAHB w Mirisku, F. } 1800 \text {, op. } 1 \text {, } \\
\text { nr } 1, \text { k. } 219 v\end{array}$ \\
\hline 34 & $\begin{array}{l}\text { Krystyna Paciukowna } \\
\text { 1v. Wojciechowa Puznikowa } \\
\text { 2v. Piotrowa Marcinowiczowa } \\
\text { mieszczka z Przedmieścia } \\
\text { Zaniemeńskiego }\end{array}$ & $8 \begin{array}{lll}8 I I & 1673\end{array}$ & 1673 & $\begin{array}{l}\text { NAHB w Miŕsku, F. 1800, op. 1, } \\
\text { nr 1, k. } 254 v-255\end{array}$ \\
\hline 35 & $\begin{array}{l}\text { Adam Ćwiklicz } \\
\text { burmistrz }\end{array}$ & 5 VI 1673 & 7 a 14 VII 1673 & $\begin{array}{l}\text { NAHB w Mińsku, F. 1800, op. } 1 \text {, } \\
\text { nr 1, k. 260v-261 }\end{array}$ \\
\hline 36 & $\begin{array}{l}\text { Hans Hansbach } \\
\text { aptekarz }\end{array}$ & $5 \quad$ IX 1673 & 14 IX 1673 & $\begin{array}{l}\text { NAHB w Mińsku, F. 1800, op. } 1 \text {, } \\
\text { nr 1, k. 266v-267v; } \\
\text { NAHB w Mińsku, F. 1761, op. 1, } \\
\text { n r 2,k. 350-351 }\end{array}$ \\
\hline 37 & $\begin{array}{l}\text { Anna Czernikowna } \\
\text { Fiedorowa Bobrykiewiczowa } \\
\text { wdowa po Iawniku }\end{array}$ & 2 IV 1674 & $\begin{array}{l}4 \mathrm{~V} \text { a } 16 \text { VII } \\
1674\end{array}$ & $\begin{array}{l}\text { N } А \text { HB w Mińsku, F. 1800, op. } 1 \text {, } \\
\text { nr } 1, \text { k. } 278-279\end{array}$ \\
\hline 38 & $\begin{array}{l}\text { Ohopia Cimochowna } \\
\text { Mikola jowa Jędrzejczykowa } \\
\text { wdowa }\end{array}$ & 19 IX 1674 & 16 II 1675 & $\begin{array}{l}\text { NAHB w Mińsku, F. } 1761 \text {, op. } 1 \text {, } \\
\text { nr } 2, k .405 \text { - oryginal }\end{array}$ \\
\hline 39 & $\begin{array}{l}\text { Szyınon Hurinowicz } \\
\text { jurydyczanin proboski }\end{array}$ & $7 \times 1675$ & 1675 & $\begin{array}{l}\text { NAHB w Mińsku, F. } 1761 \text {, op. } 1 \text {, } \\
\text { nr } 2, k .409-\text { oryginal }\end{array}$ \\
\hline $40 \mathrm{~A}$ & $\begin{array}{l}\text { Teodor Karny inieszczanin, } \\
\text { zarządca dworu Labno } \\
\text { dzierżawy Jana Antoniego } \\
\text { Chrapowickiego wojewody } \\
\text { witebskiego }\end{array}$ & 20 II 1676 & 201111676 & $\begin{array}{l}\text { NAHB w Mirisku, F. } 1800 \text {, op. } 1 \text {, } \\
\text { nr 1. k. } 302-303\end{array}$ \\
\hline 41 & $\begin{array}{l}\text { Marcin Makowski } \\
\text { rajca }\end{array}$ & $18 \vee 1689$ & 1011690 & $\begin{array}{l}\text { NAHB w Mirisku, F. 1761, op. 1, } \\
\text { nr 3, k. 15-16v }\end{array}$ \\
\hline 42 & $\begin{array}{l}\text { Wojciech Gawroński } \\
\text { mieszczanin }\end{array}$ & $26 \quad 111 \quad 1690$ & 1690 & $\begin{array}{l}\text { NAHB w Mińsku, F. 1761, op. } 1 \text {, } \\
\mathrm{nr}: 3, \text { k. } 32-33 v\end{array}$ \\
\hline 43 & $\begin{array}{l}\text { Stanislaw .Joszkiewicz } \\
\text { mieszczanin ze wsi niejskiej } \\
\text { Baranowicze }\end{array}$ & 12 V $1694 ?$ & XVII & $\begin{array}{l}\text { NAHB w Mirisku, F. } 1761 \text {, op. } 1 \text {, } \\
\text { nr } 2, k .126 \text { [brak konica], - } \\
\text { oryginal }\end{array}$ \\
\hline 44 & $\begin{array}{l}\text { Bartlomiej Paweł } \\
\text { pisarz radziecki }\end{array}$ & 24 IV 1710 & 24 ?VII 1717 & $\begin{array}{l}\text { NAHB w Mińsku, F. 1761, op. } 1 \text {, } \\
\text { nr } 5, k .17 v-19 v\end{array}$ \\
\hline 45 & $\begin{array}{l}\text { Mateusz Masłowski } \\
\text { kupiec }\end{array}$ & $30 \times 11 \quad 1712$ & 121713 & $\begin{array}{l}\text { LPAH w Wilnie, F. } 1282 \text {, op. } 1 \text {, } \\
\text { nr } 5308, \text { k. 9-10v - oryginal }\end{array}$ \\
\hline 46 & $\begin{array}{l}\text { WIadyslaw Dorzbach } \\
\text { burmistrz }\end{array}$ & $\begin{array}{l}\text { b. d. przed } \\
1717 \mathrm{r} \text {. }\end{array}$ & 20 V 1720?? & $\begin{array}{l}\text { NAHB w Mirisku, F. 1761, op. } 1 \text {, } \\
\text { nr } 5, \text { k. } 41\end{array}$ \\
\hline
\end{tabular}


Agnieszka Pisanko-Borowik

\begin{tabular}{|c|c|c|c|c|}
\hline $\mathrm{Nr}$ & Imię i nazwisko & $\begin{array}{l}\text { Data } \\
\text { sporządzenia }\end{array}$ & $\begin{array}{c}\text { Data } \\
\text { aktykacji }\end{array}$ & Sygnatura, uwagi \\
\hline 47 & $\begin{array}{l}\text { Eliasz Iwaniszewski } \\
\text { rybak }\end{array}$ & 1 IX 1723 & 15 IX 1723 & $\begin{array}{l}\text { NAHB w Mirisku, F. 1761, op. 1, } \\
\text { nr 5, k. 63-65 }\end{array}$ \\
\hline 48 & $\begin{array}{l}\text { Zygmunt Szulc } \\
\text { rajca }\end{array}$ & 30 III 1724 & 30 III 1724 & $\begin{array}{l}\text { LPAH w Wilnie, F. 1282, op. 1, } \\
\text { nr 5308, k. 19-20v Wypis z ks. } \\
\text { magdeburskich }\end{array}$ \\
\hline 49 & $\begin{array}{l}\text { Roman Makar } \\
\text { mieszczanin z Baranowicz }\end{array}$ & $13 । 1729$ & 1 II 1729 & $\begin{array}{l}\text { NAHB w Minisku, F. 1761, op. } 1 \text {, } \\
\text { nr 6, k. 124-5 }\end{array}$ \\
\hline 50 & $\begin{array}{l}\text { Mateusz Waszkiewicz } \\
\text { (Woszkiewicz) mieszczanin } \\
\text { z Gibulicz }\end{array}$ & 6 VI 1733 & 16 VI 1733 & $\begin{array}{l}\text { NAHB w Mirisku, F. 1761, op. I, } \\
\text { nr } 7, \text { k. } 433-435\end{array}$ \\
\hline 51 & $\begin{array}{l}\text { Teresa Dorzbachowna } \\
\text { Józefowa Wolkowa } \\
\text { mieszczka z Baranowicz, } \\
\text { córka burmistrza }\end{array}$ & $29 \times 111732$ & $17 \times 111734$ & $\begin{array}{l}\text { NAHB w Mińsku, F. 1761, op. 1, } \\
\text { nr } 7 \text {, k. 473-476 }\end{array}$ \\
\hline 52 & $\begin{array}{l}\text { Gabriel Mit kiewicz } \\
\text { mieszczanin z Mitkiewicz }\end{array}$ & 14 VI 1735 & 17 VIII 1735 & $\begin{array}{l}\text { NAHB w Minisku, F. 1761, op. } 1 \text {, } \\
\text { nr } 7 \text {, k. 553-556 }\end{array}$ \\
\hline 53 & $\begin{array}{l}\text { Katarzyna Ćwikliczówna } \\
\text { 1v. Piotrowa Wróblewska } \\
\text { 2v. Markiewiczowa }\end{array}$ & 5 VIII 1738 & 18 VIII 1738 & $\begin{array}{l}\text { NAHB w Mirisku, F. } 1761 \text {, op. } 1 \text {, } \\
\text { nr } 8, \text { k. } 235-238\end{array}$ \\
\hline 54 & $\begin{array}{l}\text { Marianna z Paszkiewiczów } \\
\text { Józefowa Badarakowa } \\
\text { burmistrzowa grodzierıska }\end{array}$ & 19 IX 1741 & $3 \times 1741$ & $\begin{array}{l}\text { I.PAH w Wilnie, F. 1282. op. 1, } \\
\text { nr 5308, k. 22-23. - Oryginal. } \\
\text { Aktykacja NAHB w Mirisku, } \\
\text { F. } 1711 \text {, op. } 1 \text {, nr } 30, \\
\text { k. } 625 v-631\end{array}$ \\
\hline 55 & $\begin{array}{l}\text { Brygida z Hlebowskich } \\
\text { Michalowa Úscinowiczowa } \\
\text { mieszczka z Gibulicz }\end{array}$ & 4 VII 1743 & 8 VII 1743 & $\begin{array}{l}\text { NAHB w Miŕsku, F. } 1761, \text { op. } 1 \\
\text { nr } 9, \text { k. } 43-44 v\end{array}$ \\
\hline 56 & $\begin{array}{l}\text { Józef Wolk } \\
\text { mieszczanin z Baranowicz }\end{array}$ & 29 VII 1744 & 7 VIII 1744 & $\begin{array}{l}\text { NAHB w Mirisku, F. } 1761 \text {, op. } 1 \text {, } \\
\text { nr } 9 \text {, k. 126-7 }\end{array}$ \\
\hline 57 & $\begin{array}{l}\text { Wladystaw Chajkiewicz } \\
\text { mieszczanin }\end{array}$ & 17 IV 1749 & $7 \times$ XII 1757 & $\begin{array}{l}\text { NAHB w Mińsku, F. 1761, op. 1, } \\
\text { nr 11, k. } 231\end{array}$ \\
\hline 58 & $\begin{array}{l}\text { Józef Solinka } \\
\text { mieszczanin }\end{array}$ & $2 I 1750$ & $11 I 1751$ & $\begin{array}{l}\text { NAHB w Mirisku, F. 1761, op. } 1 \text {, } \\
\text { nr } 10, \text { k. 403-406 }\end{array}$ \\
\hline 59 & $\begin{array}{l}\text { Józef Kalinowski } \\
\text { mieszczanin z Grandzicz }\end{array}$ & $26 \vee 1750$ & 30 VI 1750 & $\begin{array}{l}\text { NAHB w Mińsku, F. 1761, op. } 1 \text {, } \\
\text { nr } 10, \text { k. } 387-390\end{array}$ \\
\hline 60 & $\begin{array}{l}\text { Anna Jakubowa } \\
\text { Iwaniszewska } \\
\text { mieszczka z Adamowicz }\end{array}$ & $5 \vee 1752$ & $9 \vee 1752$ & $\begin{array}{l}\text { NAHB w Mirisku, F. } 1761 \text {, op. } 1 \text {, } \\
\text { nr } 9, \text { k. } 497 \cdots 498 v\end{array}$ \\
\hline 61 & Marcin Iwaniszewski & 3 IV 1753 & 9 IV 1753 & $\begin{array}{l}\text { NAHB w Mińsku, F. 1761, op. } 1 \text {, } \\
\text { nr 10,k. 601-604 }\end{array}$ \\
\hline 62 & $\begin{array}{l}\text { Maciej Kasianowicz } \\
\text { \& Baranowicz }\end{array}$ & $16 \times 111754$ & $20 \times 111754$ & $\begin{array}{l}\text { NAHB w Mińsku, F. } 1761 \text {, op. } 1 \text {, } \\
\text { nr } 10, \text { k. } 789-792\end{array}$ \\
\hline 63 & $\begin{array}{l}\text { Donicella z Szarkowskich } \\
\text { Andrzejowa Pisankowa } \\
\text { mieszczka z Przedmieścia } \\
\text { Zaniemeńskiego }\end{array}$ & $30 \vee 1757$ & 6 VI 1757 & $\begin{array}{l}\text { NAHB w Mińsku, F. 1761, op. } 1 \text {, } \\
\text { nr } 11, k .185-188\end{array}$ \\
\hline 64 & $\begin{array}{l}\text { Ewa z Laskiewiczów } \\
\text { Felic janowa Legatowiczowa } \\
\text { wdowa po lawniku }\end{array}$ & 6 VI 1757 & 7 VI 1757 & $\begin{array}{l}\text { NAHB w Mirisku, F. 1761, op. } 1 \text {, } \\
\text { nr } 11 \text {, k. 189-192 }\end{array}$ \\
\hline
\end{tabular}




\begin{tabular}{|c|c|c|c|c|}
\hline $\mathrm{Nr}$ & Imię i nazwisko & $\begin{array}{c}\text { Data } \\
\text { sporządzenia }\end{array}$ & $\begin{array}{c}\text { Data } \\
\text { aktykacji }\end{array}$ & Sygnatura, uwagi \\
\hline 65 & $\begin{array}{l}\text { Anastazja z Wasilewskich } \\
\text { Pietkiewiczowa jurydyczanka } \\
\text { z jurydyki kolegiackiej } \\
\text { jezuitów }\end{array}$ & $51 \times 1757$ & $61 \times 1757$ & $\begin{array}{l}\text { NAHB w Mińsku, F. } 1761 \text {, op. } 1 \text {, } \\
\text { nr } 11 . \text { k. } 209-212 \text {. Oryginal }\end{array}$ \\
\hline 66 & $\begin{array}{l}\text { Audoksja Janowa } \\
\text { Kasparewiczowa mieszczanka } \\
\text { z Baranowicz }\end{array}$ & 1 III 1758 & 17 VII 1758 & $\begin{array}{l}\text { NAHB w Mińsku, F. 1761, op. 1, } \\
\text { nr } 11, \text { k. 381-384 }\end{array}$ \\
\hline 67 & $\begin{array}{l}\text { Marianna Garbowszczanka } \\
\text { Franciszkowa Juchnewiczowa } \\
\text { mieszczka z Adamowicz }\end{array}$ & 5 VI 1758 & 12 VIII 1758 & $\begin{array}{l}\text { NAHB w Mińsku, F. } 1761 \text {, op. } 1 \text {, } \\
\text { nr } 11, \text { k. 393-396 }\end{array}$ \\
\hline 68 & $\begin{array}{l}\text { Katarzyna z Horbaczewskich } \\
\text { Antonina Starzyńska }\end{array}$ & [1759] & & $\begin{array}{l}\text { LPAH w Wilnie, F. } 1282 \text {, op. } 1 \text {, } \\
\text { nr } 4346, k .1 \text { - oryginal }\end{array}$ \\
\hline 69 & $\begin{array}{l}\text { Godfryd Born } \\
\text { linnik }\end{array}$ & 24 XI 1766 & $29 \times I 1766$ & $\begin{array}{l}\text { NAHB w Mińsku, F. 1761, op. } 1 \text {, } \\
\text { nr } 12, k .731-4\end{array}$ \\
\hline 70 & $\begin{array}{l}\text { Jan Mickiewicz } \\
\text { mieszczanin z Mickiewicz }\end{array}$ & $2 \mathrm{i}$ VI 1774 & 3 VI 1791 & $\begin{array}{l}\text { NAHB w Mińsku, F. } 1761 \text {, op. } 1 \text {, } \\
\text { nr } 15, \text { k. } 82-85\end{array}$ \\
\hline 71 & $\begin{array}{l}\text { Maryna z Makarewiczów } \\
\text { Franciszkowa Taurelowa } \\
\text { mieszczka z Mickiewicz }\end{array}$ & 10 VI 1775 & $10 \times 1792$ & $\begin{array}{l}\text { NAHB w Mińsku, F. } 1761 \text {, op. } 1 \text {, } \\
\text { nr } 15, \text { k. 971-4 }\end{array}$ \\
\hline 72 & $\begin{array}{l}\text { Andrzej Janucewicz } \\
\text { majster cechu rzeźnickiego }\end{array}$ & $15 \times 1778$ & 4 XI 1778 & $\begin{array}{l}\text { NAHB w Mińsku, F. } 1761 \text {, op. } 1 \text {, } \\
\text { nr } 6 \text {, k. 1260-1 }\end{array}$ \\
\hline 73 & $\begin{array}{l}\text { Karol Topolski } \\
\text { rajca grodzieński } \\
\text { i pocztmajster białostocki }\end{array}$ & 17 XII 1783 & 17 I 1784 & $\begin{array}{l}\text { NAHB w Miŕsku, F. 1761, op. 1, } \\
\text { nr 13, k. 296-299 }\end{array}$ \\
\hline 74 & $\begin{array}{l}\text { Antoniego Makarewicz } \\
\text { miecznik }\end{array}$ & 3 III 1787 & 14 III 1787 & $\begin{array}{l}\text { NAHB w Mińsku, F. } 1761 \text {, op. } 1 \text {, } \\
\text { nr } 14, \text { k. 83-5 }\end{array}$ \\
\hline 75 & $\begin{array}{l}\text { Wojciech Hadyka } \\
\text { stelmach }\end{array}$ & $14 \times 1789$ & $17 \times 1789$ & $\begin{array}{l}\text { NAHB w Mińsku, F. 1761, op. 1, } \\
\text { nr 14, k. } 915-917\end{array}$ \\
\hline 76 & $\begin{array}{l}\text { Piotr Juszkiewicz } \\
\text { mieszczanin z Baranowicz }\end{array}$ & 24 XI 1789 & 12 IV 1790 & $\begin{array}{l}\text { NAHB w Mińsku, F. } 1761 \text {, op. } 1 \text {, } \\
\text { nr } 14, \text { k. } 998-1001\end{array}$ \\
\hline 77 & $\begin{array}{l}\text { Ludwik Benedykt } \\
\text { Laffaye lawnik }\end{array}$ & $1 \vee 1790$ & $4 \vee 1790$ & $\begin{array}{l}\text { NAHB w Mińsku, F. } 1761 \text {, op. } 1 \text {, } \\
\text { nr 14, k. } 1118-1025\end{array}$ \\
\hline 78 & $\begin{array}{l}\text { Johana Gotlib } \\
\text { Giimsch mieszczanin }\end{array}$ & 1811791 & 19 I 1791 & $\begin{array}{l}\text { NAHB w Mińsku, F. 1761, op. 1, } \\
\text { nr 15, k. 13-15 }\end{array}$ \\
\hline 79 & $\begin{array}{l}\text { Mateusz Żyliński } \\
\text { mieszczanin z Baranowicz }\end{array}$ & 9 III 1791 & 18 III 1791 & $\begin{array}{l}\text { NAHB w Mińsku, F. 1761, op. 1, } \\
\text { nr 15, k. 49-51 }\end{array}$ \\
\hline 80 & Feliks Lenkiewicz & $10 \times I I 1791$ & $12 \times 11792$ & $\begin{array}{l}\text { NAHB w Miŕsku, F. 1761, op. } 1 \text {, } \\
\text { nr 15, k. 1003-1004 }\end{array}$ \\
\hline 81 & $\begin{array}{l}\text { Michal Lukaszewicz } \\
\text { mieszczanin z Lapienek }\end{array}$ & $23 \vee 1793$ & $30 \times 1793$ & $\begin{array}{l}\text { NAHB w Mińsku, F. } 1761 \text {, op. 1, } \\
\text { nr 15, k. 1343-5 } \\
\text { - LPAH w Wilnie, F. 1282, } \\
\text { op. 1, nr 4487, k. 1-2. } \\
\text { Wypis z ksiąg magistratu } \\
\text { 30.X.1793 }\end{array}$ \\
\hline 82 & $\begin{array}{l}\text { Andrzej Stoliński } \\
\text { rajca }\end{array}$ & 16 I 1796 & 16 II 1796 & $\begin{array}{l}\text { NAHB w Mińsku, F. 1761, op. 1, } \\
\text { nr } 17, \text { k. 103-6 }\end{array}$ \\
\hline
\end{tabular}




\section{The last wills of Grodno townsmen in the $17^{\text {th }}$ and $18^{\text {th }}$ centuries}

\section{Abstract}

The present article describes the specific nature of last will documents. It discusses in detail all the sections of 81 wills written in Grodno in the $17^{\text {th }}$ and $18^{\text {th }}$ centuries. The analysis of the content of these texts provides a lot of information about their authors: their profession, possessions, religious beliefs, where they wanted to be buried, how important religion was to them, as well as the nature of their family relationships which is manifested in what they willed to whom.

The last wills of Grodno townsmen from the years 1640-1796 were written in accordance with certain patterns, similarly to the wills written by townsmen in Sieradz, Pabianice or Kielce. In Grodno, most of these documents were approved by the chief administrator or juror of the city; in the $18^{\text {th }}$ century, also by a Soviet administrator. Last wills were usually written in the testator's house, right before their death.

The most unique documents from the corpus are the original versions of the wills, these kinds of documents rarely survived in the original versions. Among the 81 testaments, 22 documents were made by the members of the patriciate. There are also wills made by artisans, merchants, a pharmacist, as well as the inhabitants of the villages near Grodno. The full list of the testators can be found in the appendix to the article. Most of the testators were Roman-Catholics. They did not leave any detailed suggestions for their burial ceremonies. They made one person responsible for the burial, stated what amount of money was to be spent on the ceremony, and asked for a mass. They rarely left cash to be spent on their burial; usually, they ordered a part of their property to be sold for that purpose; sometimes the heirs had to pay for the funeral. However, not all the wills contain funeral instructions. The main motivation behind writing the last will seems to have been in most cases the testator's intention to prevent conflicts between their heirs. The few instances of leaving money to religious institutions seem to confirm this view: only 27 testators out of 81 left some of their possessions to religious institutions: money, land, clothes or dishes. Cash was rarely willed in such instances; debts that other people had failed to pay the testators before they died were more common: the institutions were expected to exact the money themselves. Moreover, the heirs were reluctant to give the possessions willed to church, they often ceded this responsibility to their heirs.

The most important kind of property included in the wills was land: $69 \%$ of wills contain statements of this kind. It does not necessarily mean that the inhabitants of Grodno were farmers, though, the patriciate and the inhabitants of the nearby villages owned most of the land.

The testators rarely left gold, silver, tin or copper to their heirs; cash was willed even less often. Such donations decreased in number in the $18^{\text {th }}$ century, which is explained by the testators by the losses they suffered as a result of plundering during "Moscow deluge".

It should be noticed that historians have been interested in testaments written in big cities, such as Gdansk, Kraków, Warsaw for a long time. Testaments written 
in smaller cities, such as Sieradz, Przemyśl or Pabianice have also been analysed. However, all these publications discuss the documents produced in the Kingdom of Poland ("Korona"), whereas the last wills written in The Grand Duchy of Lithuania remain largely neglected.

\section{Завешания гродненксих мешан в XVII-XVIII вв.}

\section{Резюме}

В статье указана специфика завешательной документации, способов ее составления, поэтому подробно представлены отдельные части 81 завешания. Анализируя содержание распоряжения последней воли гродненских мешан, мы можем узнать: кем были авторы, какова была их функция или профессия, кем были по вероисповеданию, где желали быть похоронены и каково значение придавали религии, каким имушеством расіолагали, как выглядели семейные отношения, то есть кому и что записано в наследство.

Завешания гродненских мецан 1640-1796 составлены по определенной схеме, подобно тому как подвергнутые источниковедческому анализу завецгания серадзских, пабьяницких или келецких мешцан. В Гродно в болыпинстве случаев они составлялись перед представителем войтовско-магистратского управления, в XVIII веке также перед представителем городского совета. Как правило завеццание делали в доме завешателя, обычно недолго до сметри.

В анализируемом собрании заслуживают внимания, встретившиеся редко, оригинальные завешания. Среди 81 завешания - 22 документа были сдельаны членами патрициата. Имеются тоже завешания ремесленников, купцов, аптекаря, а также жителей городских деревень. Их подробный перечень указан в приложении. Болынинство авторов - это представители римско-католического вероисповедания. Похоронительные распоряжения, будушие одной из частей завешания, не были детальными. Назначались человек, который должен был заняться похоронами, сумма на их отправление, место похоронения, а также просьба о заупокойных обеднях. Очень редко предназначались наличные чаше всего велено продать часть имущества или похоронительные расходы возлагались на наследников. Однако не во всех завешаниях появляются похоронительные распоряжения. Земные хлопоты -- имущественные, их упорядочение и предохранение от возможных притязаний и конфликтов между наследниками - главная причина составления завешаний. Количество записов на религиозные цели, кажется, подтверждает этот тезис. Линь 27 авторов из 81 жертвовалю на религиозные цели -- деньги, земельные владения, одежду, посуду. Редкостью было жертвование наличными - обысно это были долги, которые одаренные должны были взыскать. С другой стороны, наследники не спепили исполнять записанные костелу жертвы, поручая их исполнение своим наследникам.

Наиболее значительное место в завешаемом имушестве занимали возделываемые земли. Такого рода записи составляют $69 \%$. Это отнюдь не должно 
обозначать, что жители Гродно занимались сельским хозяйством. Болыне всего земли находилось во владении патрициата и жителей городских деревень.

Гродненские авторы завешаний релко передавали в наследие золото, серебро, олово, медь. Дарственные записи наличных случались еше реже. Четко тоже замечается, что количество таких записей уменьшастся в XVIII веке. Авторы завешаний обосновывают это разорением, наступившим после «московского потопа».

В заключение я хотела бы отметить, что завецания из большых городских центров: Гданьска, Кракова, Варшавы лавно вызываюо интерес историков. Был тоже проведен источниковедческий анализ актов последней воли жителей меныших городов - Серадза, ІІшемысля, ІІабьяниц. Однако эти публикации касаются территории ПІольского Королевства. А о завешаниях из территории Великого княжества Јитовского мы знаем немного. 